Portland State University

PDXScholar

Fall 12-13-2013

\title{
Scenario Development and Analysis of Freshwater Ecosystem Services under Land Cover and Climate Change in the Tualatin and Yamhill River Basins, Oregon
}

Robert Wesley Hoyer

Portland State University

Follow this and additional works at: https://pdxscholar.library.pdx.edu/open_access_etds

Part of the Fresh Water Studies Commons, and the Water Resource Management Commons Let us know how access to this document benefits you.

\section{Recommended Citation}

Hoyer, Robert Wesley, "Scenario Development and Analysis of Freshwater Ecosystem Services under Land Cover and Climate Change in the Tualatin and Yamhill River Basins, Oregon" (2013). Dissertations and Theses. Paper 1512.

https://doi.org/10.15760/etd.1508

This Thesis is brought to you for free and open access. It has been accepted for inclusion in Dissertations and Theses by an authorized administrator of PDXScholar. Please contact us if we can make this document more accessible: pdxscholar@pdx.edu. 
Scenario Development and Analysis of Freshwater Ecosystem Services under Land Cover and Climate Change in the Tualatin and Yamhill River Basins, Oregon

$$
\text { by }
$$

\title{
Robert Wesley Hoyer
}

\begin{abstract}
A thesis submitted in partial fulfillment of the requirements for the degree of

\author{
Master of Science \\ in \\ Geography
}

\author{
Thesis Committee: \\ Heejun Chang, Chair \\ Martha Works \\ David Ervin
}

\section{Portland State University 2013}


(C) 2013 Robert Wesley Hoyer 


\begin{abstract}
Humans make decisions within ecosystems to enhance their well-being, but choices can lead unintended consequences. The ecosystem services (ES) approach supports decisionmaking that considers all environmental goods and services. Many challenges remain in the implementation of the ES approach like how specific ES vary through space and time. We address this research problem using the Tualatin and Yamhill river basins in northwestern Oregon as a study area. Freshwater ES are quantified and mapped with the spatially-explicit ES modeling tool, Integrated Valuation of Ecosystem Services and Tradeoffs (InVEST). In chapter II, we develop a simple urban land cover change modeling approach with selected stakeholder input. The products of this analysis are used in part to answer the question of how the freshwater ES of water yield, nutrient retention, and sediment retention will change in the future, and how their distribution potentially will change? In chapter III, these ES are modeled in InVEST using the land cover scenarios and three downscaled global climate models. The base period is 1981 to 2010 and the future period is 2036 to 2065 . The models are calibrated to empirical estimates, and display different sensitivities to inputs. Water yield increases with higher rainfall but decreases with the highest temperature scenario. Nutrient export and retention estimates are positively correlated. In the Tualatin basin, more urban lands generally lead to increases in nutrient exports and retention. The effect is reversed in the Yamhill basin from much larger agricultural exports. Sediment exports and retention increase with higher winter rainfall but are negatively spatially correlated due to topographic effects. Simulation of a landscape scale installation of riparian buffers leads to decreases in
\end{abstract}


exports and increases in retention. The distribution of the provision of freshwater ES remains unchanged throughout the scenarios. With few parameters in each InVEST model, all display a high degree of sensitivity. Parameterization is subject to high uncertainty even with calibrated values. We discuss the assumptions and limitations of InVEST's freshwater models. The spatially explicit nature of InVEST is its main advantage. This work coupled with other analyses in the study area can facilitate the identification of tradeoffs amongst ES leading to better ecosystem management. 


\section{Acknowledgements}

This thesis would not have been possible without a number of people. First, I would like to thank my advisor, Dr. Heejun Chang for affording me this opportunity and his guidance through the process. I very much appreciate the efforts of my committee members Dr. Martha Works and Dr. David Ervin. Their comments and suggestions were invaluable for improving the final manuscript. I would also like to thank the entire faculty and staff of the Geography Department for providing me a rewarding and stimulating educational experience. John Rockie provided scholarship funding that supported me while finishing up my work. I would like to thank the members of the land use workshop for their time and input which helped shape a large portion of the work in this thesis. I would especially like to thank Dennis Yee of Metro and Steve Kelly of Washington County for volunteering additional time to provide helpful comments. I would like to thank the Spatial Ecosystem Services Analysis, Modeling and Evaluation research team for being a part of the journey and their support along the way. I would especially like to thank Mike Psaris for being an excellent collaborator throughout the project. Lastly, I want to thank all of my fellow students. It was a pleasure sharing this experience with all of you. 


\section{Table of Contents}

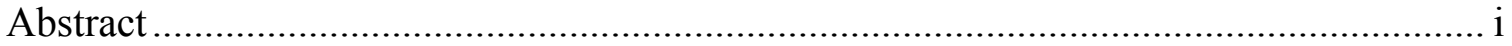

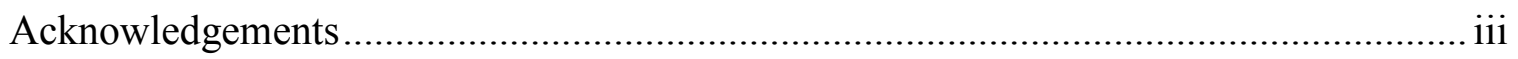

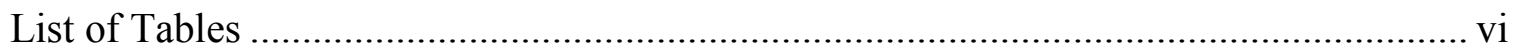

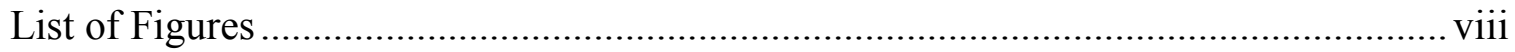

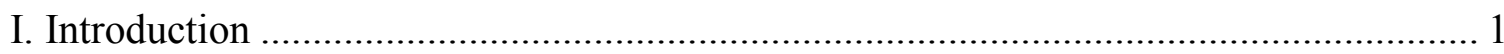

II. Engaging stakeholders for the development of future urban land cover change scenarios in the metropolitan fringe, Oregon, U.S.A............................................... 6

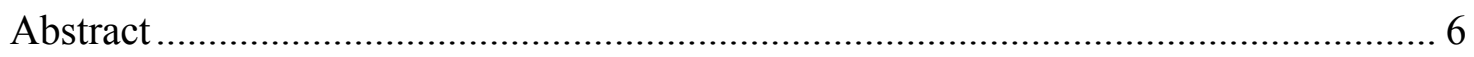

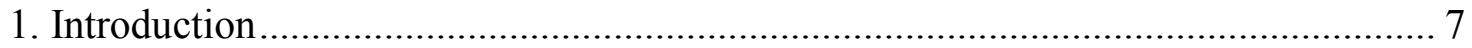

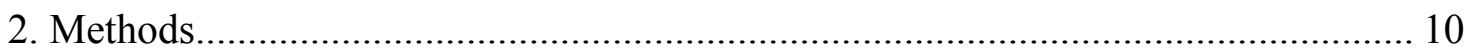

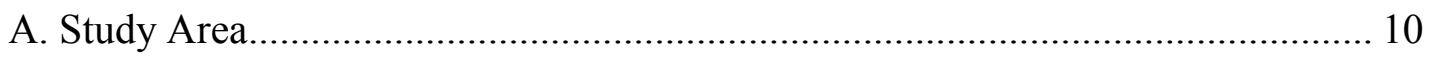

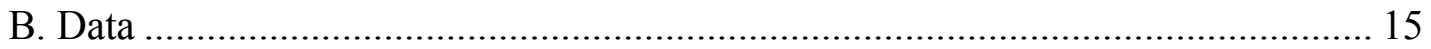

C. Construction of Scenarios with Stakeholder Consultation................................ 16

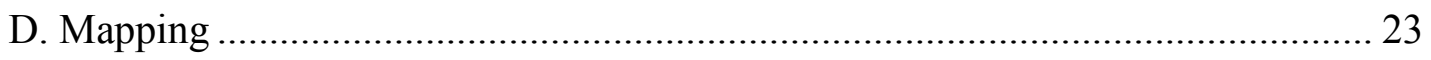

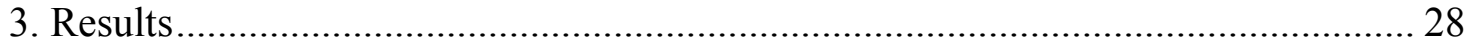

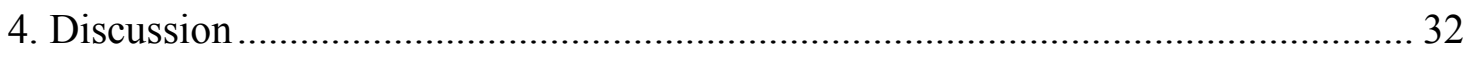

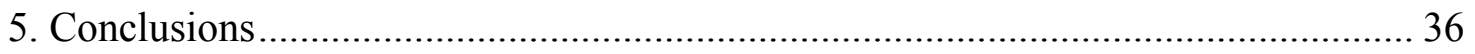

III. Assessment of freshwater ecosystem services in the Tualatin and Yamhill basins

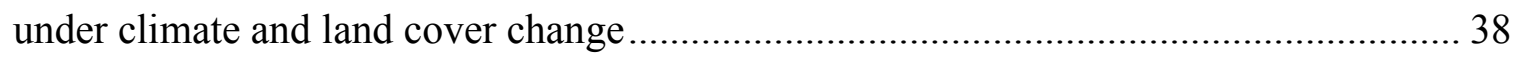

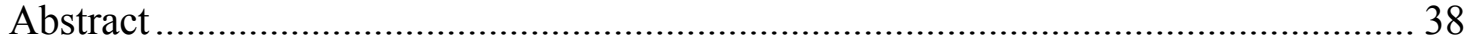

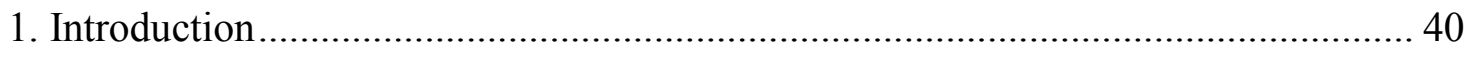

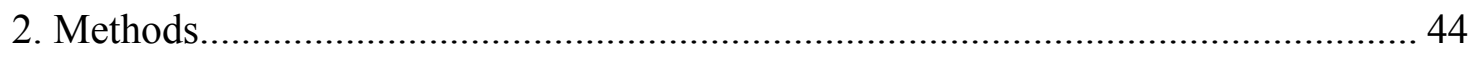

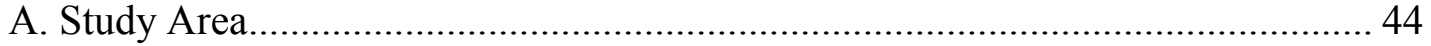

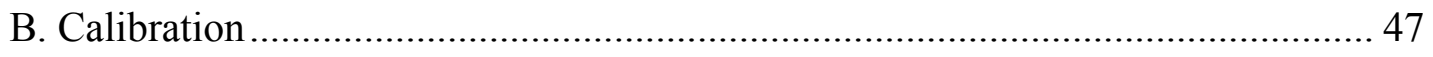

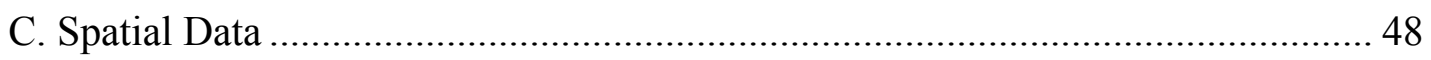

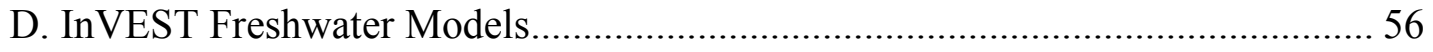

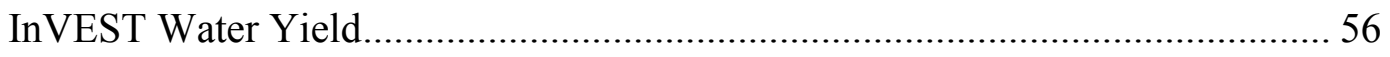

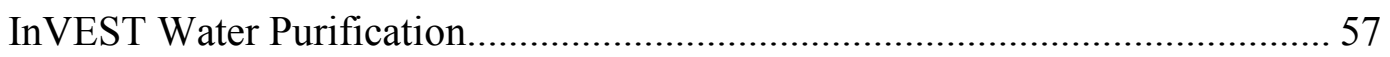

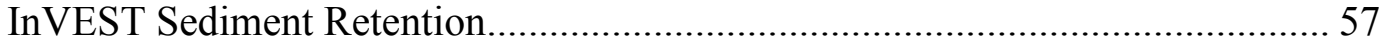




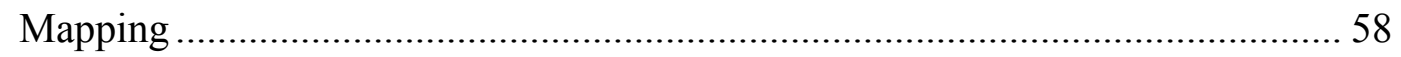

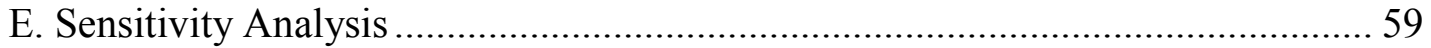

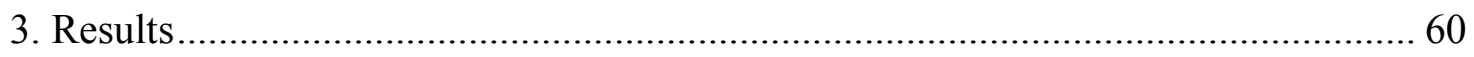

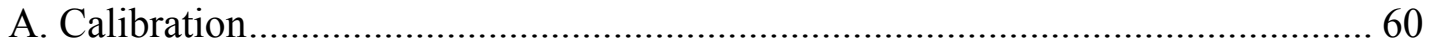

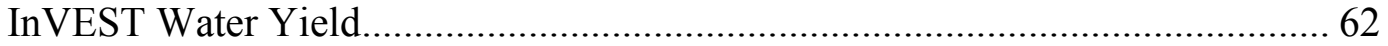

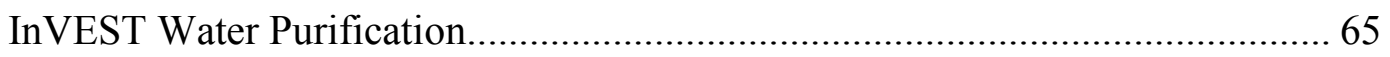

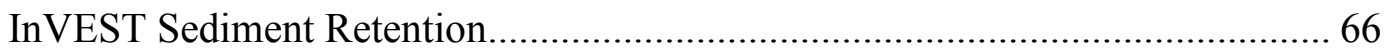

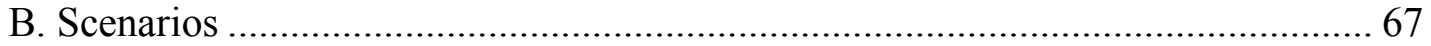

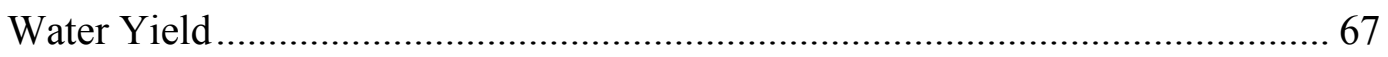

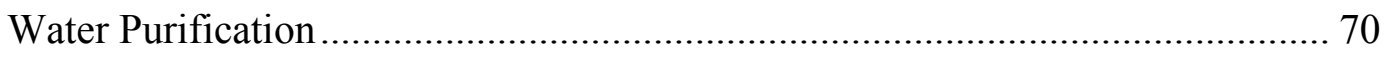

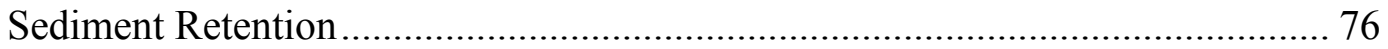

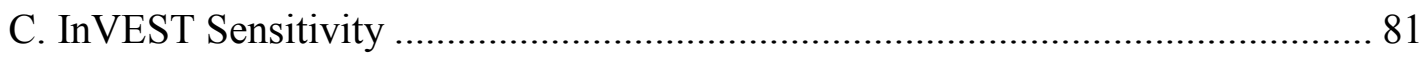

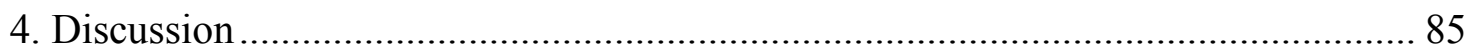

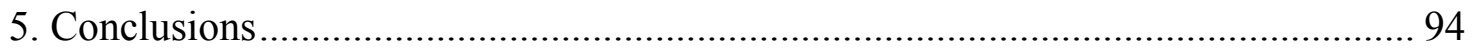

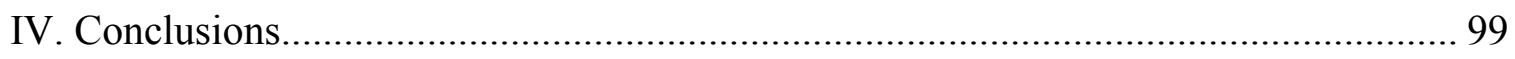

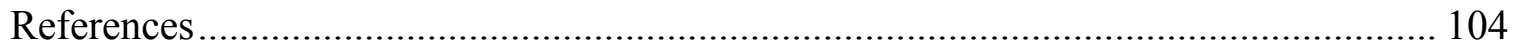

Appendix A: Chapter II Supplementary, Geoprocessing and Scripting Methods .......... 116 Appendix B: Chapter III Supplementary, Additional Methods, Results, and Model

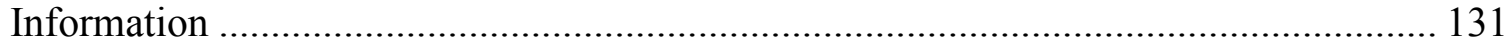




\section{List of Tables}

Table 2.1: Populations of the two counties comprising the majority of the study area as well as the largest cities

Table 2.2: Data sources used to create a spatial mask and graded weights map used as inputs to a modeled creating future scenario maps in the Tualatin and Yamhill River Basins Region.

Table 2.3: Summary of the metrics used to calculate the area needed for each developed land cover category projected to increase by the year 2050 for a model creating future land cover scenario maps.

Table 2.4: Summary of growth in each developed land cover in each future scenario expressed as total new hectares and percent increase.

Table 2.5: Results of pairwise analytical hierarchy process (AHP) for each spatial variable incorporated into the final graded map that guides the allocation of new urban land cover grid cells in three scenarios of increased urbanization.

Table 3.1: Summary of a selection of studies using Integrated Valuation of Environmental Services and Tradeoffs (InVEST) in the academic literature

Table 3.2: Data Requirements and Sources for the InVEST Freshwater Models. A Water Yield, B - Water Purification, C - Sediment Retention

Table 3.3: Load estimator program LOADEST results for three water quality parameters (Total Nitrogen - TN, Total Phosphorus - TP, Total Suspended Sediments - TSS) for sites in the Tualatin Basin (3) and Yamhill Basin (1), Oregon, U.S.A............................61

Table 3.4: Results of InVEST water yield calibration at eight flow gauges in the Tualatin and Yamhill basin study area.

Table 3.5: Output of InVEST water purification for total phosphorus two locations on the Tualatin River at two different time periods of varying amounts of annual average water yield.

Table 3.6: Results of calibration for sub-watersheds inside the study area modeled with InVEST's water purification model for total nitrogen (TN) and total phosphorus (TP)...66

Table 3.7: Results of calibration for sub-watersheds inside the study area modeled with InVEST's sediment retention model. 
Table 3.8: Sensitivity analysis of parameters in the InVEST water yield model ..... .81

Table 3.9: Sensitivity analysis of parameters in the InVEST water purification model. ..82

Table 3.10: Sensitivity analysis of parameters in the InVEST water purification model. 85 


\section{List of Figures}

Figure 2.1: Study Area including the current urban growth boundaries around each municipality

Figure 2.2: Annual increase in population density for two counties making up the majority of the study area

Figure 2.3: Conceptual diagram of the stakeholder consultation process informing the development of the modeling approach used to produce future land use scenarios

Figure 2.4: Maps of the six criteria used to construct the graded weights map......

Figure 2.5: Maps representing potential future urban land cover change in a study area mostly comprised of the Tualatin and Yamhill river basins.

Figure 2.6: Inset maps of potential land cover change in the Yamhill and Tualatin river basins focusing on the area encompassing the cities of Newberg and Dundee

Figure 2.7: Example of grid cell raster mosaic phenomena occurring in maps depicting potential future land cover change.

Figure 3.1: Study Area - The Tualatin and Yamhill River Basins and the interstitial Chehalem Creek watershed.

Figure 3.2: Differences in daily maximum temperature averaged by month and average monthly precipitation for the climate datasets in the scenario analysis for assessing waterrelated ecosystem services in the Tualatin and Yamhill Basin study area for three downscaled climate models.

Figure 3.3: Difference in winter and summer average maximum daily air temperature $\left(\mathrm{C}^{\circ}\right)$ by sub-watershed in the Tualatin and Yamhill basin study area for three downscaled climate models.

Figure 3.4: Percent difference in winter and summer precipitation $(\mathrm{mm})$ by sub-watershed in the Tualatin and Yamhill basin study area for three downscaled climate models.

Figure 3.5: Scatterplot of all InVEST estimates against empirical observations for each sub-basin's average annual water yield

Figure 3.6: Matrix of maps depicting percent change in water yield estimates modeled by InVEST from a historic baseline under scenarios of climate and land cover change 
Figure 3.7: Matrix of maps depicting percent change in total nitrogen (TN) export estimates modeled by InVEST from a historic baseline under scenarios of climate and land cover change.

Figure 3.8: Matrix of maps depicting percent change in total phosphorus (TP) export estimates modeled by InVEST from a historic baseline under scenarios of climate and land cover change.

Figure 3.9: Matrix of maps depicting percent change in total nitrogen (TN) retention estimates modeled by InVEST from a historic baseline under scenarios of climate and land cover change.

Figure 3.10: Matrix of maps depicting percent change in total nitrogen (TN) retention estimates modeled by InVEST from a historic baseline under scenarios of climate and land cover change.

Figure 3.11: Matrix of maps depicting percent change in sediment export estimates modeled by InVEST from a historic baseline under scenarios of climate and land cover change.

Figure 3.12: Matrix of maps depicting percent change in sediment retention estimates modeled by InVEST from a historic baseline under scenarios of climate and land cover change.

Figure 3.13: Matrix of maps depicting bundled freshwater ES modeled by InVEST from a historic baseline under scenarios of climate and land cover change.

Figure 3.14: Graph showing the symmetrical response of the export and retention estimate to the percent retention parameter in the InVEST water purification model. ....83

Figure 3.15: Results of C-factor sensitivity analysis for the InVEST sediment model.....84 


\section{Introduction}

The scientific community has acknowledged the fact that earth's ecosystems are dominated by humanity. The most remote environments and the largest global scale biophysical processes are not without influence from collective human activities.

Consumption of energy harnessed from fossil life has led to clear signal of human alteration by the increase in atmospheric carbon dioxide (Vitousek, Mooney, Lubchenco, $\&$ Melillo, 1997). What this means for the biosphere and the human species is still a matter of intense investigation. The evidence suggests that natural systems have departed from the long term average variability for the planet. This is especially true for climate, biodiversity loss rates, and nutrient cycling dynamics. A great deal of uncertainty comes with reaching thresholds in these systems never observed during the rise and continued growth of civilization. It is argued that staying within the limits to which humans have historically adapted and thrived is the safest course of action (Rockström et al., 2009). The Millennium Ecosystem Assessment (MA, 2005) identified ecosystem degradation as a major obstacle towards global development goals, and developing sustainable practices is essential to meet future needs in basic resources like food, water, fiber, and shelter. Conversion from natural land cover types to human-dominated ones is the major driver of degradation. As croplands and urban areas supplant natural ecosystems, there is a tradeoff where productivity for human consumptions is increased, but biological diversity is lost and ecological functions are simplified leading to vulnerability to biological invasions and disease and other unforeseen problems (Foley et al., 2005).

The ultimate driver in determining ecosystem structure and function is climate. The climate's influence has a profound effect on an ecosystems ability to cope with 
disturbance, and can eventually lead to a long term shift in its fundamental workings (Staudinger et al. 2012). The scientific community has gathered a large body of data describing a warming earth, which has led to observable changes in terrestrial and aquatic biological systems. The evidence strongly suggests that this is the result of human induced increases in greenhouse gas emissions to the atmosphere (IPCC, 2007). In addition and related to land cover change, climate change is identified as the second major driver of ecosystem change (MA, 2005).

Of course it is easier to formulate the problem than to execute a solution, and a linear model of pristine nature to degradation is an oversimplification. In reality humans and natural systems are so tightly coupled, they form social ecological systems with their own system behavior that can indeed be resilient by absorbing disturbances and still operate in fundamentally the same way (Liu et al., 2007). Human management decisions are a primary factor in how a social ecological system behaves and finding solutions that lead to a desired stable state involves learning and an adaptive capacity when shocks and disturbances do happen (Folke et al., 2002). The MA identified the ecosystem services (ES) concept as an approach that could offer a path towards sustainable management of ecosystems. A desirable stable state for a given area would be one that provides a flow of goods and services essential to human well-being, but often the full set is not recognized and one provisioning service like food production dominates decision-making (MA, 2005). The argument goes that an adaptation in management to correct the problem is to assign values to each service facilitating assigning the costs and benefits of competing services (Costanza et al., 1997; Daily, 1997). 
After many years developing in academia, the ES concept is starting to be embraced by policy and management community from the national to local scale (Cochran \& Logue, 2011; EPA, 2009; Smith et al., 2011). There are still a number of large challenges facing it that must be addressed prior to more widespread implementation in the environmental policy and management community. These include the actual definition of ES, their classification, quantification methods, how to involve the relevant stakeholders, and since ES are spatially explicit, how to consistently map them (de Groot, Alkemade, Braat, Hein, \& Willemen, 2010). On top of these issues, we can assume social ecological systems are highly dynamic, and will change over time for a variety of reasons. How will this affect ES? A considerable amount of effort and debate will need to take place to resolve these issues. This thesis is an attempt to address aspects of these research problems. This project only focuses on a subset of ES at only one scale to keep the objectives within an achievable scope. Using a landscape or regional scale and a biophysical unit of the watershed, we pose several research questions related to the freshwater ES of the Tualatin and Yamhill river basins of northwest Oregon. They are as follows:

- It is assumed that our study area will see changes in land use/land cover (LULC) in the upcoming years and decades. Given that LULC change is a main driver in ecosystem change, how can we develop possibilities of how might this change occur? Can we do this with comments from stakeholders while keeping the scope modest and achievable given limited time and resources? 
- Can we use modeling tools developed to quantify ES to estimate the future change in amount of water-related ecosystem services (WES) relative to current estimates? Will these tools allow us to incorporate the main variables identified above that will cause the amount of WES to change, climate and LULC?

- Given that ES also vary in space, what is the spatial distribution of the supply of WES currently and how might it potentially change in the future? Can we depict the estimates of the amount of ES in our study in a spatially explicit manner through maps of our study area?

- After conducting this assessment, can we provide useful information to land managers and a critique of the methods that will be useful to land managers and future research efforts?

To answer these questions, we will be using the conceptual tool of scenario analysis. Scenarios in our case can be defined as possible futures (Peterson, Cumming, \& Carpenter, 2003). They are a projection exercise rather than prediction. They provide a useful way to sketch out forecasts of the future with a level of plausibility "while explicitly incorporating relevant science, societal expectations, and internally consistent assumptions about major drivers, relationships, and constraints" (Thompson et al., 2012). Our scenarios are based on changes in LULC focusing on urban growth and landscapewide changes in management practices in the form of riparian buffer strips, and three potential future climate regimes represented by statistically downscaled global climate models (GCMs). This thesis addresses the first research question by developing a simple 
method to model future urban land cover. The results of that analysis are presented in chapter two.

The modeling tool Integrated Valuation of Environmental Services and Tradeoffs (InVEST) will be used to answer the second and third research questions. A number of tools are being developed by a number of groups to assess ES (Daily \& Nelson, 2010) with InVEST being one the major initiatives. It is a modeling tool developed by the Natural Capital Project (www.naturalcapitalproject.org), a partnership of several nonprofit organizations and academic institutions. Its goal is to provide a modeling environment for estimating the provision of a full suite of ES in order to facilitate valuation, trade-off analysis, and decision-making. It is an effort to address a portion of the challenges facing ES mentioned earlier by building a framework that is credible, replicable and scalable which it is hoped will contribute a body of evidence that will be persuasive to decision-making institutions of the ES approached utility (Daily et al., 2009). InVEST is integrated into a geographic information system (GIS). It has the capability of using spatially explicit datasets to quantify estimations of ecosystem services, thus providing the capability to map the results. Already recognized by the research community, several published studies used it to evaluate ecosystem service provision (Bai, Zhuang, Ouyang, Zheng, \& Jiang, 2011; Nelson et al., 2009; Polasky et al., 2010). InVEST will be used to investigate how freshwater ES will potentially vary in time and space in our study area. This work is presented in the third chapter of the thesis. Discussion of the benefits of the analyses and their limitations will also be provided. Concluding comments and remarks will be presented in the final chapter. 
II. Engaging stakeholders for the development of future urban land cover change scenarios in the metropolitan fringe, Oregon, U.S.A.

\begin{abstract}
Land use/land cover (LULC) maps are major data input for ecosystem service mapping. This paper describes the process of creating future scenarios of LULC in 2050 using the input from stakeholders for the Tualatin and Yamhill river basins of Oregon. Their comments led to the state's regulatory land use system being used as the primary factor in how the landscape will change over time. Additionally, other biophysical and socioeconomic factors were used as secondary factors that affect the future landscape. The rates of growth were determined by basic assumptions linked to population growth. We used a geographic information system process that both graded the landscape based on a set of criteria and constrained where change can occur. Based on different assumptions of growth rate and urban density, three scenarios of high, medium, and low growth were produced. Results of the analysis indicate that growth is heaviest in areas near the current urban landscape and is driven to areas legally designated for future urban expansion. The approach highlights a way to rapidly create scenarios that provide utility toward the goal of quantifying and mapping the provision of ecosystem services. This study provides a simple but transparent approach that can appeal to stakeholders engaged in potential land use policies geared towards management of ecosystem services.
\end{abstract}




\section{Introduction}

The ecosystem service (ES) concept continues to receive attention as new way of understanding and managing humanity's relationship with nature (Costanza et al., 1997; Daily, 1997; de Groot, Wilson, \& Boumans, 2002). Several research trajectories are underway in the ES literature including the continued development of ES assessment techniques which include methods of quantification and mapping (Burkhard et al., 2012). Ecosystem goods and services do not inhabit space and time uniformly, and there are increasing efforts to estimate the spatial distribution of ES through maps (Chan, Shaw, Cameron, Underwood, \& Daily, 2006; Egoh et al., 2008; Troy \& Wilson, 2006). Making accurate estimates of ES that are spatially explicit at a scale appropriate to the relevant management and decision-making institutions remain a key challenge moving forward (Crossman, Bryan, de Groot, Lin, \& Minang, 2013). Land use/land cover (LULC) maps are typically the means towards making ES spatially explicit and are employed in the majority of ES mapping studies (Martinez-Harms \& Balvanera, 2012; Schägner, Brander, Maes, \& Hartje, 2013). LULC data are useful for a variety of ES mapping methods from simple proxy to process-based approaches, and are instrumental in assessing the impact of landscape pattern on ES provision (Su, Xiao, Jiang, \& Zhang, 2012).

Human pressures on the environment have their most apparent manifestation in the visible transformation of the earth's surface. Over the last 50 to 100 hundred years, the most important factor in the change in terrestrial ES has been land cover conversion (MA, 2005; Foley et al., 2005), and this trend is likely continue in the future (Seto, Güneralp, \& Hutyra, 2012). LULC maps offer a way to document and quantify these 
changes in ES (Gulickx, Verburg, Stoorvogel, Kok, \& Veldkamp, 2013). Improvements to remote sensing technology over the last several decades have enhanced the ability to observe the outcomes of social and ecological processes on the landscape (Turner, Lambin, \& Reenberg, 2007). Another set of challenges facing the ES concept is predicting how the stocks and flows of ES will change over time. This is crucial information for planning for the continued provision of ES. This also necessitates understanding how patterns of LULC will change as well. Although precise prediction of land use is impossible given the plethora of uncertainties, creating a series of possibilities given the available information can still provide useful insights when planning for the future. These possibilities or scenarios provide a useful way to sketch out the future with a level of plausibility "while explicitly incorporating relevant science, societal expectations, and internally consistent assumptions about major drivers, relationships, and constraints" (Thompson et al., 2012). Scenario analysis has already been used to investigate national-scale land use strategies (Bateman et al., 2013), identify trade-offs and inform local land use decisions (Goldstein et al., 2012) in an ES context.

The societal consideration aspect of scenario production is difficult to address. For LULC change, and especially modeling future change, decomposing all the socioeconomic processes involved is exceedingly difficult. Instead, it can be beneficial to reach out to stakeholders. They are society members who are interested in the issue and whose decisions can have consequences on the landscape. Their inclusion can help to create plausibility in a scenario modeling exercise. Stakeholders bring an elevated level 
of utility to an ES assessment as their knowledge reflects potential for policy-induced changes to the landscape (Swetnam et al., 2011).

The research objective is to develop maps of future LULC scenarios that will be integrated into an assessment of ES for a portion northwestern Oregon experiencing a high degree of urban development pressure. Other studies have done similar work for a larger spatial extent using stakeholder engagement (Hulse, Branscomb, \& Payne, 2004). This work required several years with numerous iterations that struck a balance in defining assumptions along a gradient of citizen engagement and expert-opinion for mapping outcomes to reach satisfactory results. Several studies also used stakeholder input to created alternate visions in study areas dominated by agriculture (Boody et al., 2005; Santelmann, et al., 2004; Waldhardt et al., 2010) or forests (Price et al., 2012). These studies necessitated a high level of coordination between researcher and stakeholder participants using a variety of methods like focus groups and online workshops using an iterative process. The broad scope of these projects is often outside the feasibility of many research and management budgets. Others have created models that allow for rapid generation of land use scenarios (Westervelt, BenDor, \& Sexton, 2011). They note that with greater uncertainty and greater stakeholder interest like in land use planning, decision-makers prefer their own judgment for planning rather than model results. With this in mind, we attempt to create a simple hybrid modeling framework that integrates judgment from stakeholders with local expertise on LULC into GIS-based land cover change modeling. The approach taken here is to take information gleaned from a single workshop with individuals engaged in the land management narrative in our study 
area as well as a few additional one-on-one conversations and use these as guiding principles for developing assumptions of future land cover change. With this scope in mind, we focused on the consequences of increased urban development along the urban rural fringe, where most future land conversions are likely to occur in the study area.

\section{Methods}

\section{A. Study Area}

The Tualatin and Yamhill basins drain a northwest portion of the Willamette Valley, and are 1,858 and 2,000 square kilometers, respectively (Figure 2.1). They hold a highly complex social-ecological system covering the three broad land typologies of western Oregon, developed lands, agriculture, and natural vegetation dominated by upland forests. The greater Portland metropolitan area includes the northern urban portion of the study area. Washington and Yamhill counties whose areas approximately correspond to the majority of the study area have experienced rapid growth since 1980 (Table 2.1) continuing a legacy of population growth in the Portland metropolitan area over the last century (Oregon Metro, 2009). The city of Hillsboro, a west Portland suburb has more than tripled in population between 1980 and 2010. Washington County is seeing higher population density increase than the average for the area approximately corresponding to the north Willamette Valley region (Figure 2.2). 
Table 2.1

Populations of the two counties comprising the majority of the study area as well as the largest cities (Oregon Blue Book, 2013).

\begin{tabular}{lccccc}
\hline County & Pop. 1980 & Pop. 1990 & Pop. 2000 & Pop. 2010 & 30 yr. change \\
\hline Washington & 245,860 & 311,554 & 445,342 & 529,710 & $115.4 \%$ \\
Yamhill & 55,332 & 65,551 & 84,992 & 99,193 & $79.3 \%$ \\
\hline Large Cities & Pop. 1980 & Pop. 1990 & Pop. 2000 & Pop. 2010 & 30 yr. change \\
\hline Beaverton & 31,962 & 53,307 & 76,129 & 89,803 & $181.0 \%$ \\
Hillsboro & 27,664 & 37,598 & 70,186 & 91,611 & $223.2 \%$ \\
McMinnville & 14,080 & 17,894 & 26,499 & 32,187 & $128.6 \%$ \\
Newberg & 10,394 & 13,086 & 18,064 & 22,068 & $112.3 \%$ \\
\hline
\end{tabular}




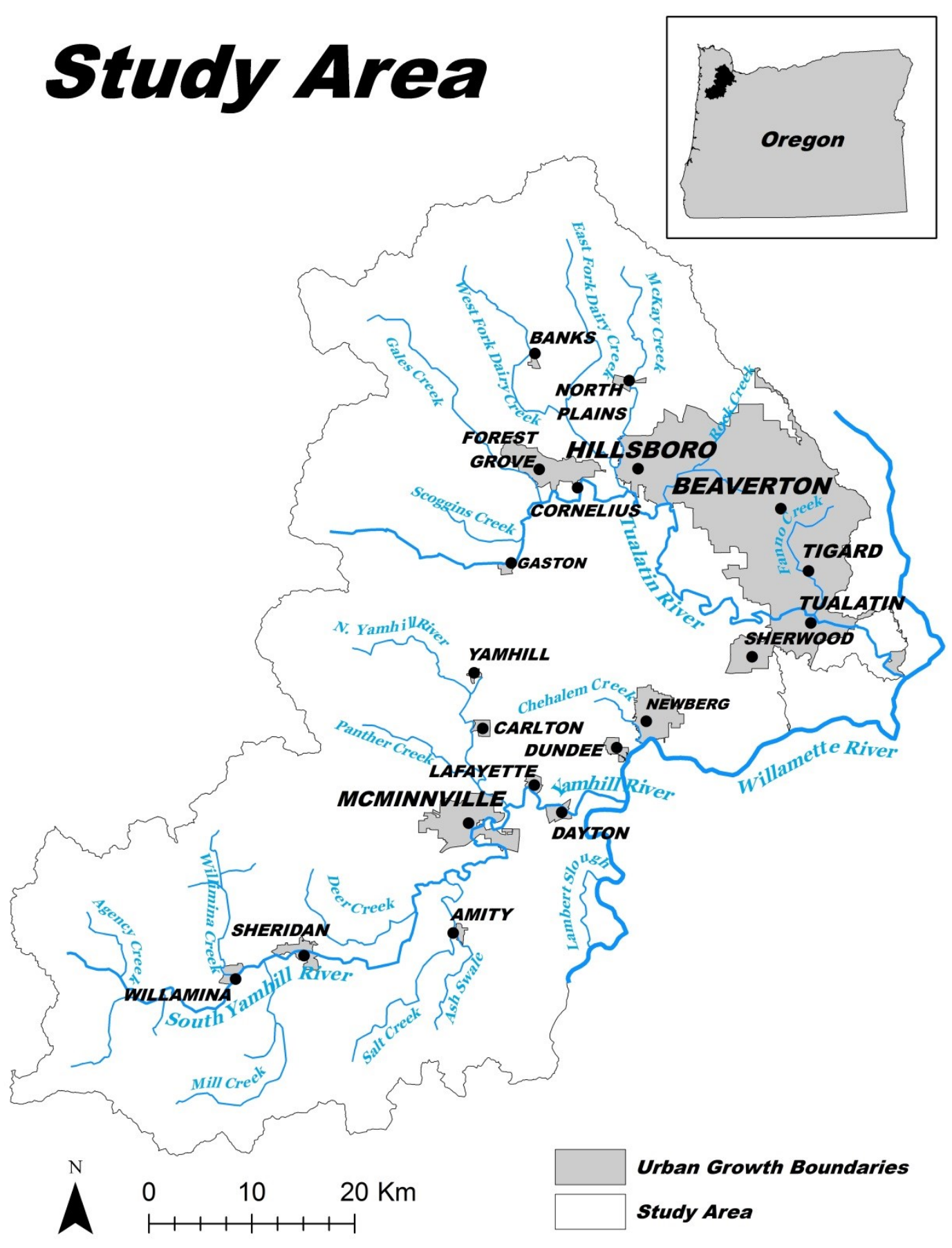

Figure 2.1

Study Area including the current urban growth boundaries around each municipality. It is dominated by the Tualatin and Yamhill river basins. The smaller Chehalem Creek watershed that lies in between the two larger basins is also included as well as a portion of land bordering the west bank of the Willamette River. 


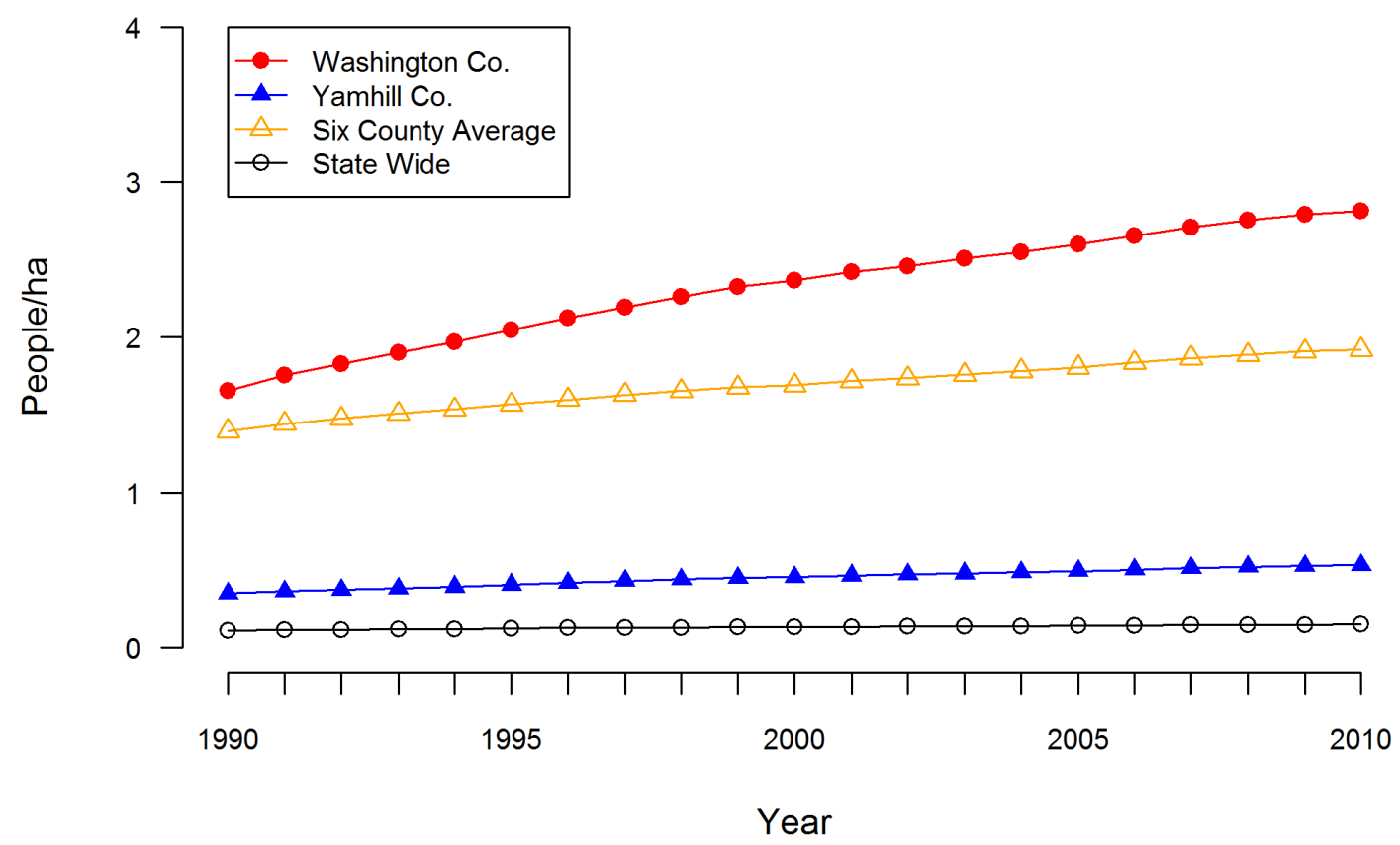

Figure 2.2

Annual increase in population density (people/ha) for two counties making up the majority of the study area (Washington and Yamhill Counties). The density increase for the state as a whole and the six Oregon counties approximately making up the northern portion of the Willamette Basin (Clackamas, Columbia, Marion, Multnomah, Washington, and Yamhill Counties) are included for reference. Data from Portland State College of Urban and Public Affairs Population Research Center (2013)

With their close proximity to Portland, these basins and the Tualatin in particular have come under a high level of scrutiny in the context of several environmental issues including water quality (Boeder \& Chang, 2008; Praskievicz \& Chang, 2011) and sustainable/livable community development as a product of land use planning. Both basins have stream reaches placed on the state's 303(d) list for impaired surface water bodies in accordance with the federal Clean Water Act. Issues include $\mathrm{pH}$, dissolved oxygen, total phosphorus, and ammonia and Total Maximum Daily Loads (TMDLs) have been developed for these issues (ODEQ, 2012). TMDL regulations for stream 
temperature are currently in the works. Land use plays a major role in determining water quality indicator values and stream health within both urbanizing and agricultural catchments (Johnson, Richards, Host, \& Arthur, 1997; Paul \& Meyer, 2001).

When understanding the drivers of land cover change, an institutions shaping policy needs to be considered. In 1973, the Oregon legislature passed senate bill 100, which set an institutional framework for land-use planning applying state-wide goals informed by citizens and implemented through local governments (Abbot, Howe, \& Adler, 1994). This regulatory environment is meant to first protect Oregon farmlands and also encourage livable urban communities with well-planned infrastructure. A primary tool towards this end is the implementation an urban growth boundary (UGB) for each incorporated city in the state to reduce the ill-effects of urban sprawl and encourage future efficient compact development. These UGBs effectively create a land use dichotomy of urban lands within and the resource lands on the outside. With growing interests in landowner property rights, Oregon residents passed the state ballot measure 37 in 2004 (ODLCD, 2011). The passage of the measure allowed landowners who acquired their property prior to development restrictions to file compensation claims with the state and counties or a waiver of land use regulations in lieu of a payment. The measure contained a number of ambiguities that made its implementation problematic and could possibly undermine Oregon's land use system. State ballot measure 49 replaced it in 2007 and provided more rigorous definition of compensation which in the vast majority of cases is limited to three or less new dwellings on a claimant's parcel. Another recent development also occurred in 2007 where Metro, the Portland regional governing 
agency, can propose urban and rural reserve areas (URAs and RRAs) surrounding the current UGB to plan for future growth in manner compatible with state land use planning goals, which include targeting areas for future development that limit impacts to ecological systems (ODLCD, 2013). Thus, Oregon's land use system will be the largest variable in guiding future land conversion in the state barring any major policy shifts in the legislature over the next several decades. Indeed, the analysis already performed by local agencies in defining the current UGB as well as urban reserves is what make the following analysis a practical approach for developing these land cover scenarios and can be thought of as an extension of these efforts (D. Yee, personal communication, July 11, 2013).

B. Data

The USGS National Land Cover Dataset 2006 (Fry et al., 2011) was chosen as the baseline current state in our study area for a variety of reasons. First, the dataset contains a manageable amount of classifications with 15 falling within the study area. Second, with $30 \mathrm{~m}$ resolution, the land cover data is spatially explicit, allowing a fair degree of differentiation without overwhelming the effort and the subsequent parameterization of ES models. Third, the year 2006 is the most up to date product available from the USGS. The socioeconomic calculations for this project start at 2010 to align with US Census estimates. We assume the four year difference in land cover will be negligible at the landscape scale. Several other datasets were gathered from various state and local agencies and governments. As the focus was on increase to urban development, most of 
the data was primarily composed of spatially explicit data pertaining to the Oregon land use regulation framework (Table 2.2).

Table 2.2

Data sources used to create a spatial mask and graded weights map used as inputs to a modeled creating future scenario maps in the Tualatin and Yamhill River Basins Region.

\begin{tabular}{|c|c|c|}
\hline Data Type & Description & Sources \\
\hline $\begin{array}{l}\text { Urban Growth } \\
\text { Boundaries } \\
\text { (UGB) }\end{array}$ & $\begin{array}{l}\text { Includes current UGB plus accepted and } \\
\text { proposed Urban Reserve Areas (URAs), } \\
\text { Rural Reserves with additional protection, } \\
\text { and some additional adjacent land in case } \\
\text { growth exceeds current reserves. }\end{array}$ & $\begin{array}{l}\text { Metro Regional Land and Information } \\
\text { System (RLIS) } \\
\text { (http://www.oregonmetro.gov/index.cfm/g } \\
\text { o/by.web/id=593), } \\
\text { City of McMinnville Planning Department, } \\
\text { City of Newberg Engineering Department }\end{array}$ \\
\hline Zoning & $\begin{array}{l}\text { Includes all except a few small } \\
\text { communities. A statewide layer } \\
\text { designating broad classifications (forestry, } \\
\text { agriculture, and rural residential) was } \\
\text { integrated with municipality zoning layers. }\end{array}$ & 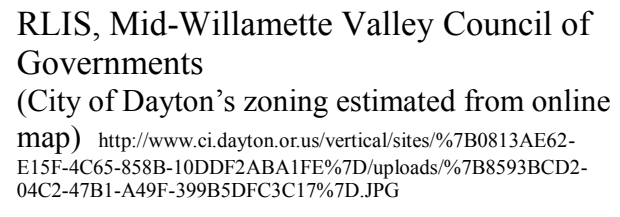 \\
\hline $\begin{array}{l}\text { Measure } 49 \\
\text { Claims }\end{array}$ & $\begin{array}{l}632 \text { claims joined to tax-lot parcel date to } \\
\text { make spatially explicit. Authorized claims } \\
\text { collected from three counties make up vase } \\
\text { majority of the study area. }\end{array}$ & $\begin{array}{l}\text { Oregon Department of Land Conservation } \\
\text { and Development, State of Oregon } \\
\text { Geospatial Enterprise Office, Yamhill } \\
\text { County Assessor's Office }\end{array}$ \\
\hline $\begin{array}{l}\text { High Value } \\
\text { Farm Soils }\end{array}$ & $\begin{array}{l}\text { Agriculture soils of US Natural Resource } \\
\text { Conservation Service Class I and II } \\
\text { (irrigated or non-irrigated) (Oregon State } \\
\text { Archives, 2012). }\end{array}$ & $\begin{array}{l}\text { Oregon Spatial Library } \\
\text { (http://spatialdata.oregonexplorer.info/geoportal } \\
\text { /catalog/main/home.page) }\end{array}$ \\
\hline $\begin{array}{l}\text { Groundwater } \\
\text { Restriction } \\
\text { Zones }\end{array}$ & $\begin{array}{l}\text { Critical and restricted groundwater zones } \\
\text { could possibly be an impediment to rural } \\
\text { residential development. Designated by } \\
\text { the Oregon Department of Water } \\
\text { Resources where aquifers are identified as } \\
\text { depleted of used at an unsustainable rate } \\
\text { (OWRD, n.d.). }\end{array}$ & Oregon Department of Water Resources \\
\hline $\begin{array}{l}\text { Protected } \\
\text { Areas }\end{array}$ & $\begin{array}{l}\text { Lands off-limits to development for a } \\
\text { variety of reasons, including federal forest } \\
\text { lands, city and state parks, private green } \\
\text { spaces, and schools. }\end{array}$ & $\begin{array}{l}\text { RLIS, US Fish Wildlife Geospatial } \\
\text { Services } \\
\text { (http://www.fws.gov/GIS/data/CadastralDB/ind } \\
\text { ex.htm) }\end{array}$ \\
\hline
\end{tabular}

C. Construction of Scenarios with Stakeholder Consultation

A preliminary mapping effort took place prior to the involvement of local

stakeholders. This was done to attempt to create a working method for creating maps 
necessary for the greater project research objectives. A geographic information systems (GIS) method offered an avenue towards creating maps that incorporated stakeholder input and were employed to evaluate ecosystem services for future scenarios (Swetnam et al., 2011). These initial maps provided a mechanism to stimulate a critical assessment of the method and to help elicit opinions on what would drive land cover change in the future and what cover classes would be "winners" and "losers." A nominal date of 2050 was chosen for the scenarios to align with ES modeling objectives.

A workshop was convened in June 2012 with four professionals chosen by a project partner actively engaged in conservation issues with our study area. They represent a cross-section of land use interests, including a representative from the Oregon Department of Agriculture, a county planner, an economist with Portland Metro administrative and planning agency, and a land use attorney. They were accompanied by a project partner, along with the university researchers. Background on the project was provided for context, and the preliminary land cover results were presented. Discussions among meeting members made it clear that the initial model input data primarily based on geographical variables such as slope, soils, distance to current land cover type were unsatisfactory. Instead, the members of the meeting identified the regulatory framework in place in the state of Oregon. Conversations focused mainly on the future of developed lands in the study area. Landscape scale expansion of agricultural and forestry land uses were deemed unlikely. This was interpreted to mean that the main focus of the modeling effort should be on the placement of new urban land cover near existing urban areas. General agreement was quickly made that the urban growth boundary (UGB) was the 
main deciding factor of the location of new urbanization. However, additional factors were identified specifically the Oregon Department of Water Resources groundwater restriction zones, high value farm soils, and measure 49 claims. There was agreement that no development would occur in protected areas.

The issue of the quantity of growth to occur received less attention. Most comments referred to standard economic variables like annual population growth, average household size, and employments rates as possibly having utility for creating plausible rates of land cover change. Members were reticent to provide tangible numbers on the amount of land that will be consumed by urban development given the uncertainties. The researchers chose three rates of annual population growth $0.6 \%, 1.5 \%$, and $2.0 \%$ as starting points for the low, medium, and high scenarios, respectively. A conversation with the participating economist confirmed that these numbers are within the historical rate of growth in this region and would produce plausible projections of population in the year 2050 . We used the year 2050 to derive the area of land needed for new development and thus the number of grid cells needed for the LULC scenario maps.

In order to link population to developed land cover growth, future households were calculated along with future jobs. Future household size (2.46) is based on the average projected household size for the Portland Metropolitan Area in 2030 (Oregon Metro, 2009), the midpoint of the study time interval. The calculation of future jobs used an employment-population (e-p) ratio of 0.44, which is consistent with 2010 US Census and Bureau of Labor statistics (US Census, 2010; US Bureau of Labor Statistics, 2013). It is likely a low estimate, but was used to account for some densification in jobs in the 
future as well as a continued aging of the population. These metrics then determined the areal amount of each urban land cover category growth. Households per hectare guided how many additional pixels of open, low, and medium development were needed for each scenario. Jobs guided the growth of high developed pixels as it is assumed that this category represents where jobs are present in commercial and industrial lands. Communications with meeting members about current residential lot sizes and the likelihood of them decreasing in the study area led to the use of an estimate of seventeen households per hectare as the target for calculating how many low and medium developed pixels would be needed. This density is much higher than the current condition, but once spread over the entire study area, it yields increases in households per hectare of $1.68,4.55$, and 7.51 for each scenario, respectively (Table 2.3). It was assumed that the proportional relationship between open and the combination of low and medium development where most areas of the dwellings are located would hold from current conditions and was used to determine the amount of additional open development pixels required. The open development classification in our study area typically covers urban green-spaces such as city parks, large lawns, and golf courses. An employment per household metric for the future study area was assigned a value of 1.2 to calculate an estimate for future jobs. Approximately eighty-six jobs per hectare was the metric used to derive the number of additional hectares of high developed land needed. This number corresponds well to the current jobs per hectare estimate of 82.38 using the 0.44 e-p ratio and NLCD 2006 high development category. Once spread over the entire study area, this leads to an increase of 1.09, 1.93, and 2.27 jobs per hectare (Table 2.3). Consulting with 
stakeholders of the meeting again confirmed that this is likely close to reality considering that many industrial facilities will continue to have low job densities like warehouses and certain manufacturing facilities.

Table 2.3

Summary of the metrics used to calculate the area needed for each developed land cover category projected to increase by the year 2050 for a model creating future land cover scenario maps. The assumed future jobs and households per hectare are used to calculate the required area. The total jobs and households per hectare are the density of increase spread over both current and future urban land cover. The study area is split into urban and rural with a $95 \% / 5 \%$ split in total growth. (Rural job densities are higher because they artificially compressed into the small amount of present urban land cover.)

\begin{tabular}{lllllr}
\hline Scenario & $\begin{array}{l}\text { Ann. } \\
\text { Pop. } \\
\text { Growth }\end{array}$ & $\begin{array}{l}\text { Future Jobs } \\
\text { per hectare } \\
\text { (acre) }\end{array}$ & $\begin{array}{l}\text { Total Jobs } \\
\text { per hectare } \\
\text { (acre) }\end{array}$ & $\begin{array}{l}\text { Future } \\
\text { Households per } \\
\text { hectare (acre) }\end{array}$ & $\begin{array}{l}\text { Total } \\
\text { Households per } \\
\text { hectare (acre) }\end{array}$ \\
\hline $\begin{array}{l}\text { Current - Urban } \\
\text { (NLCD 2006) }\end{array}$ & & & $82.4(33.3)$ & & $8.8(3.6)$ \\
$\begin{array}{l}\text { Current - Rural } \\
\text { (NLCD 2006) }\end{array}$ & & & $95.3(38.6)$ & & $3.2(1.3)$ \\
Low - Urban & $0.57 \%$ & $86.5(35)$ & $83.5(33.8)$ & $42.0(17)$ & $10.4(4.23)$ \\
Low - Rural & $0.03 \%$ & $96.4(39)$ & $95.4(38.6)$ & $6.2(2.5)$ & $3.2(1.3)$ \\
Med. - Urban & $1.43 \%$ & $86.5(35)$ & $84.3(43.2)$ & $42.0(17)$ & $13.3(5.4)$ \\
Med. - Rural & $0.08 \%$ & $96.4(39)$ & $95.4(38.6)$ & $6.2(2.5)$ & $3.2(1.3)$ \\
High - Urban & $1.90 \%$ & $86.5(35)$ & $84.7(34.3)$ & $42.0(17)$ & $14.4(5.84)$ \\
High - Rural & $0.10 \%$ & $96.4(39)$ & $95.4(38.6)$ & $6.2(2.5)$ & $3.3(1.3)$ \\
\hline
\end{tabular}

After additional follow-up consultations with certain members of the committee meeting, we split the growth between urbanizing and traditionally rural areas. Again, Oregon land use laws are structured to limit growth in rural areas and encourage eventual growth to be focused within and along the current urban fabric. Additionally, several committee members mentioned that very small "cities" in the study area identify themselves as rural even though they have UGBs. These communities and rural residences in close proximity are unlikely to expand for variety of cultural, social, economic, and infrastructural reasons. As a consequence of this observation, the study 
area was split into medium to large urban areas and the rest of the landscape. A meeting member suggested dividing the growth to $95 \%$ urban and 5\% rural. This was achieved by splitting the population growth rates by this proportion. The final areal increases for each land cover category used in the construction of the future land cover maps are summarized in Table 2.4. The scenarios were constructed heuristically using a basic stakeholder/expert consultation approach at multiple stages (Figure 2.3). The values of the metrics generated are only one way to decide how much growth should occur. They were chosen to expedite the process. They are not meant to accurately project how many people will be in the study area in the year 2050 but simply provide a way forward in scenario construction.

Table 2.4

Summary of growth in each developed land cover in each future scenario expressed as total new hectares and percent increase. Land use categories are based on those used in the USGS National Land Cover Dataset 2006.

\begin{tabular}{lrrrrrrrr}
\hline Scenario & $\begin{array}{l}\text { High Dev. Percent } \\
\text { ha (acre) }\end{array}$ & $\begin{array}{l}\text { Med. Dev. Percent } \\
\text { ha (acre) }\end{array}$ & $\begin{array}{l}\text { Increase } \\
\text { ha (acre) }\end{array}$ & $\begin{array}{l}\text { Percent } \\
\text { Increase }\end{array}$ & $\begin{array}{l}\text { Open } \\
\text { Dev. ha } \\
\text { (acre) }\end{array}$ & $\begin{array}{l}\text { Percent } \\
\text { Increase }\end{array}$ \\
\hline Low & 1250 & $37 \%$ & 603 & $5 \%$ & 944 & $5 \%$ & 260 & $5 \%$ \\
Urban & $(3089)$ & & $(1491)$ & & $(2332)$ & & $(642)$ & \\
Low & 34 & $12 \%$ & 5 & $1 \%$ & 40 & $1 \%$ & 64 & $1 \%$ \\
Rural & $(86)$ & & $(12)$ & & $(99)$ & & $(158)$ & \\
Med. & 3046 & $91 \%$ & 1805 & $16 \%$ & 2823 & $16 \%$ & 777 & $2 \%$ \\
Urban & $(7527)$ & & $(4460)$ & & $(6976)$ & & $(1921)$ & \\
Med. & 41 & $14 \%$ & 13 & $2 \%$ & 108 & $4 \%$ & 173 & $2 \%$ \\
Rural & $(101)$ & & $(33)$ & & $(268)$ & & $(427)$ & \\
High & 4331 & $129 \%$ & 2665 & $24 \%$ & 4168 & $23 \%$ & 1148 & $23 \%$ \\
Urban & $(10701)$ & & $(6585)$ & & $(10299)$ & & $(2836)$ & \\
High & 44 & $15 \%$ & 18 & $2 \%$ & 146 & $2 \%$ & 234 & $4 \%$ \\
Rural & $(109)$ & & $(45)$ & & $(362)$ & & $(578)$ & \\
\hline
\end{tabular}




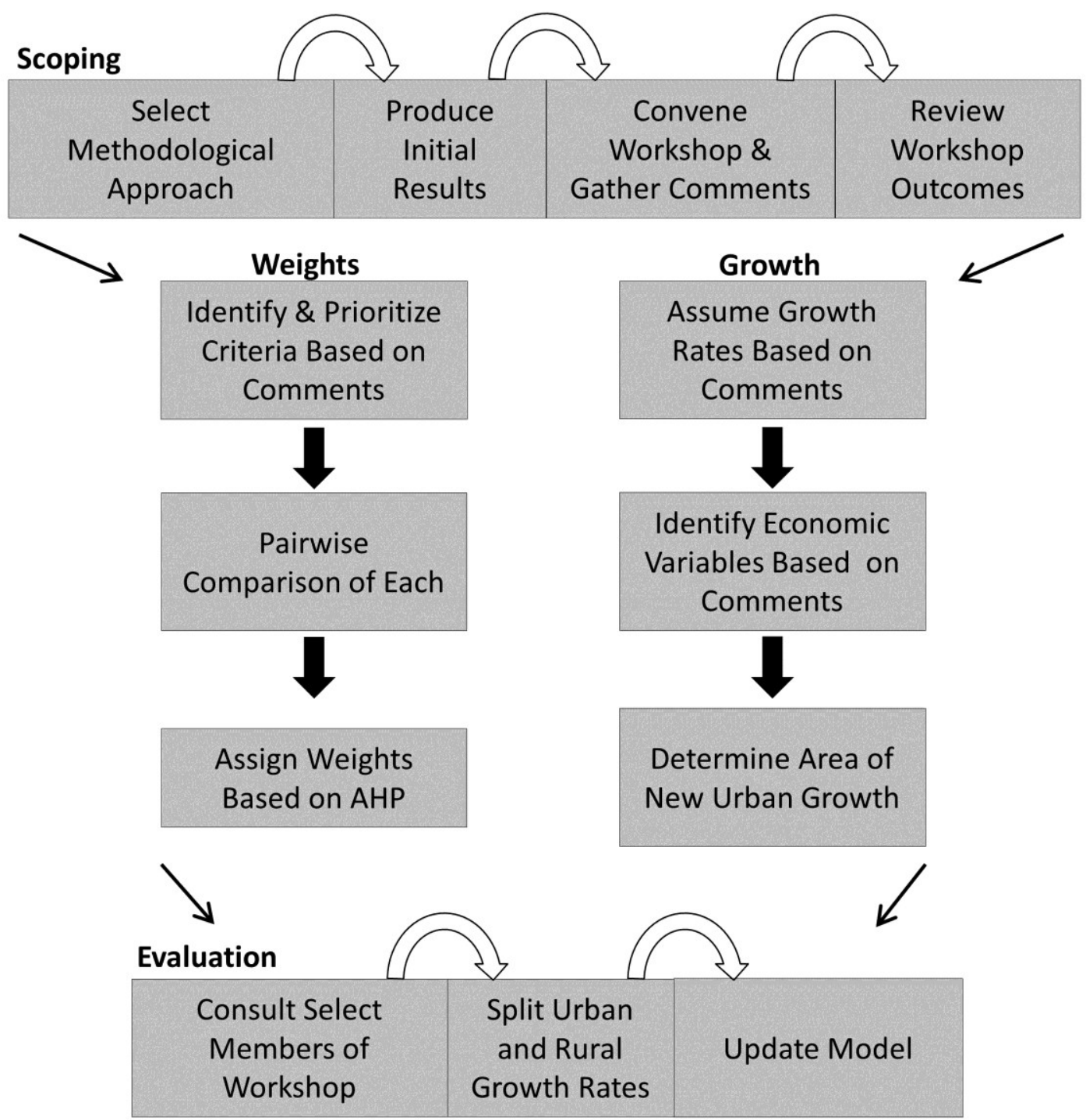

Figure 2.3

Conceptual diagram of the stakeholder consultation process informing the development of the modeling approach used to produce future land use scenarios. 


\section{Mapping}

The constructed scenarios were implemented in ArcGIS (ESRI, 2010) using a simplified, more streamlined procedure to the one presented in Swetnam et al. (2011). Their study focus was on deforestation impacts in an area where enforcement of regulations has difficulties whereas, revealed through stakeholder input and the literature, our study area's primary concern is loss of resource lands to expanding urban areas as population and economic growth demands it (Abbot et al., 1993; Walker \& Hurley, 2011). With this in mind, the future scenarios only change the amount of urban development in the study area. Remaining forest land and upland public and industrial forests do not change. The spatial configuration of agricultural and forest land cover types will undoubtedly see some shifts over the next forty years, but it is assumed that on the whole it will remain largely the same as both forestry and agricultural practices continue in the study area. This is a caveat of the current approach, as both the dual pressures of climate change, and changing drivers in markets may lead to landscape scale differences in vegetation. However, the uncertainties about future climate-driven vegetation change in 40 years and market shifts are difficult to address and quantify.

The primary challenge in building the scenario maps was how to allocate new urban pixels. Two raster (gridded) maps were employed to this end - a spatial mask and a graded weights map. The spatial mask (Figure 2.4) constrains where growth can occur. Acting as a Boolean rules map, the spatial mask reduces the number of raster cells available for transition. In the study area, the only areas considered absolutely off-limits to development are protected areas, which were constructed using the best available 
spatial data. The graded weights map assigns what areas of the study area will preferentially transition. This map incorporates the five types of spatial data described above identified by stakeholders as relevant to future urbanization. All data were converted to raster, and grid cell in the study area was graded for its potential for conversion to an urban land use classification from 1 to 9 with 9 being the highest potential of conversion. The stakeholders' comments guided these assignments, but their values were ultimately assigned by the researchers. There were usually less than nine categories per dataset, and grades were assigned based on where each was perceived to fall on the most likely to least likely to urbanize continuum. A simple binary variable like prime farm soils were graded at a one, whereas the rest of the study area was graded a nine. The UGB layer also includes the UGB, urban reserves, undesignated lands adjacent to the UGB, and rural reserves which were rated nine, eight, five, and one, respectively (Figure 2.4). A distance band of seven intervals at 150 meters each was placed immediately outside the current UGB leading to a nine (inside UGB) to one ( $>1 \mathrm{~km}$ from UGB) grade. This criterion allowed for the placement of developed grid cells to preferentially occur near the current UGB. Measure 49 claims were incorporated by randomly placing a cluster of grid cells in a claimed tax-lot is the study area graded at nine with all other cells a one. We are likely overestimating the effect of measure 49 claims even though their fraction of the study area is small $(\sim 0.15 \%)$. Since it was considered an important factor by the stakeholders, we did not want to eliminate it from our analysis. 


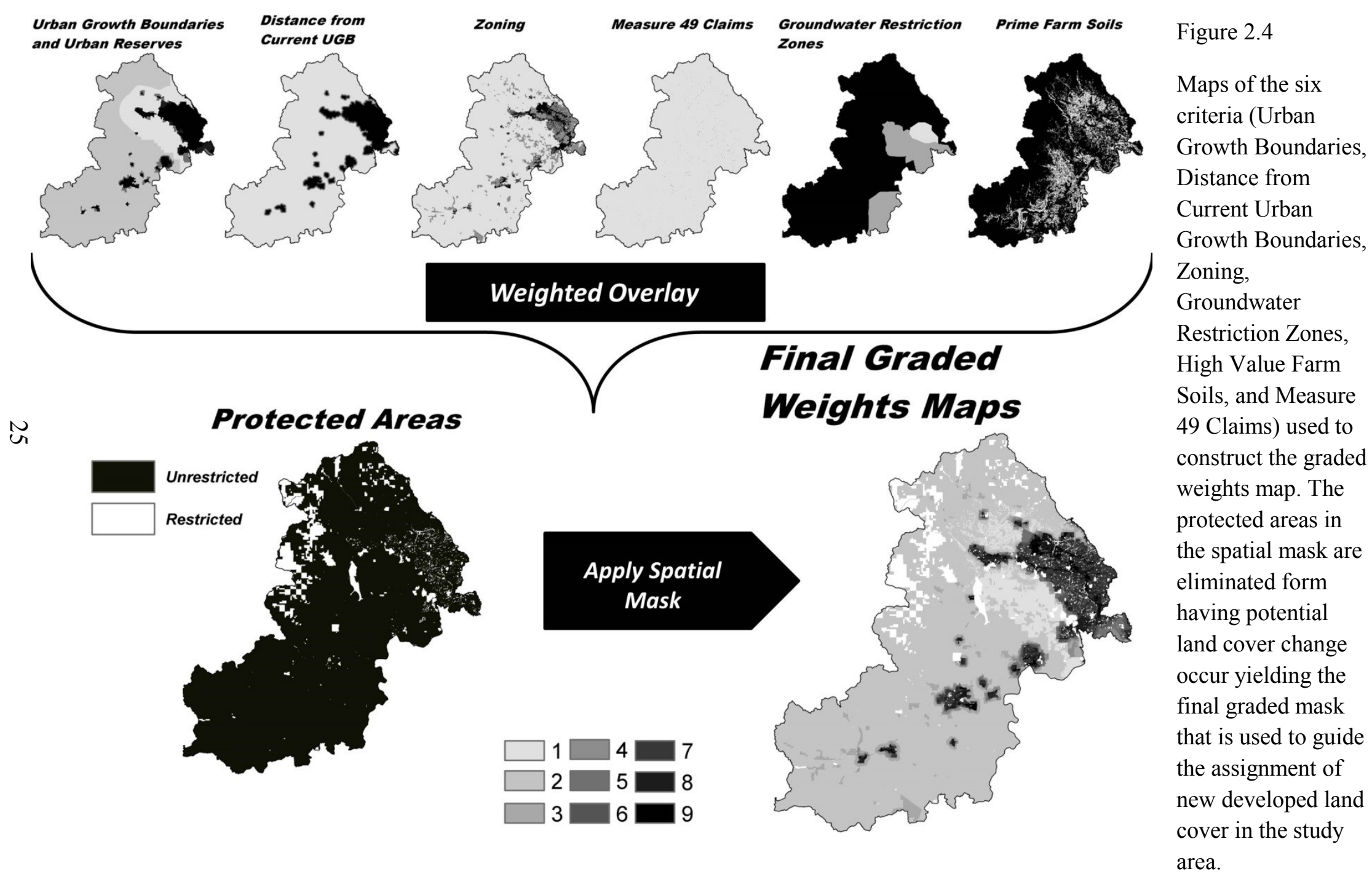


Our engagement process involved reviewing the outcomes of the workshop, and certain variables were prioritized to be more important in the analysis than others (Figure 2.3). To determine the weight of each variable, we used the pairwise analytical hierarchy process (Saaty, 1980). By comparing each variable in relation to each other variable, it provides a useful method for defining weight values. As the UGB was identified as the most important factor by the stakeholders, it received the highest weight (Table 2.5). As mentioned previously, since delineation of UGB and the URAs incorporated various forms of planning information, this single variable provides the most utility for scenario construction. After weights were determined, the weighted overlay GIS technique was employed to produce the graded map. The spatial mask is then applied eliminating all the pixels in protected areas (Figure 2.4). This finalized graded weights map now constrains and guides where each new developed grid cell is placed in the scenario maps.

The same graded map is used to guide land cover change in each classification, so the order of land cover assignment is critically important. High urban development is the first category assigned to the scenario maps. Its allocation will consume the highest graded raster cells in the graded map first. Medium development will be assigned next followed by the low and open categories. Grid cells eligible for transition to a developed land cover type fall into the agricultural and natural vegetation (i.e. forests, shrub, and grassland). High urban land cover consumes as many grid cells as needed from the highest weighted pixels. When the number of grid cells required for conversion is less than those available for the next weight score from the graded weights map, they are assigned at random. The next land cover type, medium development, is assigned the grid 
cells from the highest weighted grid cell that are still available, and proceeds to consume as many cells required for the scenario and again if more cells are available than needed from the next available weights score, they are assigned at random. This process repeats for low development and finally open development. The grid cell assignment routine, including the calculations based on the economic variable inputs, was programmed using the Python scripting language, and integrated into a script tool in the ArcGIS environment. This allows flexibility for rapidly creating additional scenarios using different parameter values (See Appendix A for additional information.)

Table 2.5

Results of pairwise analytical hierarchy process (AHP) (Saaty 1980) for each spatial variable incorporated into the final graded map that guides the allocation of new urban land cover grid cells in three scenarios of increased urbanization. The study area encompasses the Tualatin and Yamhill and basins, a region expected to see a high rate of population growth in the future. The AHP determines the weight value of each variable to be used in a weighted overlay GIS procedure.

\begin{tabular}{|c|c|c|c|c|c|c|c|c|}
\hline & $\begin{array}{l}\text { Urban } \\
\text { Growth } \\
\text { Boundary } \\
\text { (UGB) }\end{array}$ & $\begin{array}{l}\text { UGB } \\
\text { Dist. }\end{array}$ & Zoning & $\begin{array}{l}\text { Prime } \\
\text { Farm } \\
\text { Soils }\end{array}$ & $\begin{array}{l}\text { Groundwater } \\
\text { Restriction } \\
\text { Zones }\end{array}$ & $\begin{array}{l}\text { Measure } \\
49 \\
\text { Claims }\end{array}$ & $\begin{array}{l}\text { Geometric } \\
\text { Mean }\end{array}$ & Weight \\
\hline $\begin{array}{l}\text { Urban } \\
\text { Growth } \\
\text { Boundary } \\
\text { (UGB) }\end{array}$ & 1 & 3 & 2 & 9 & 9 & 9 & 4.04 & $44 \%$ \\
\hline $\begin{array}{l}\text { UGB } \\
\text { Distance }\end{array}$ & $1 / 3$ & 1 & $1 / 2$ & 7 & 9 & 5 & 1.94 & $21 \%$ \\
\hline Zoning & $1 / 2$ & 2 & 1 & 9 & 7 & 1 & 1.99 & $21 \%$ \\
\hline $\begin{array}{l}\text { Prime Farm } \\
\text { Soils }\end{array}$ & $1 / 9$ & $1 / 7$ & $1 / 9$ & 1 & $1 / 3$ & $1 / 7$ & 0.21 & $2 \%$ \\
\hline $\begin{array}{l}\text { Groundwater } \\
\text { Restriction } \\
\text { Zones }\end{array}$ & $1 / 9$ & $1 / 9$ & $1 / 7$ & 3 & 1 & 5 & 0.55 & $6 \%$ \\
\hline $\begin{array}{l}\text { Measure } 49 \\
\text { Claims }\end{array}$ & $1 / 9$ & $1 / 5$ & 1 & 7 & $1 / 5$ & 1 & 0.56 & $6 \%$ \\
\hline Total & & & & & & & 9.29 & $100 \%$ \\
\hline
\end{tabular}




\section{Results}

The three scenarios maps (Figure 2.5) show development increasing along the current urban fringe. In the low scenario, most land is consumed in an area adjacent to the city of Hillsboro (Figure 2.5) located in the west Portland metro area. This city is planning for growth as it is a hub for technology industries in the region. Other areas also receive growth resembling a "creep" around the edges of the current UGB to accommodate additional housing. This expansion intensifies in the medium scenario as commercial/industrial land cover increases more substantially in other areas, including the southern portion of the Portland metro region as well as the communities in Yamhill County centered on the county seat McMinnville. The city of Newberg, a satellite community south of the greater Portland area, also sees more significant growth. In the high scenario, a large portion of urban reserves are consumed around the western Portland metro area. There is a substantial increase in urban land around McMinnville and Newberg. Smaller communities in the study area start to see gains. In fact, Newberg begins to merge with neighboring city Dundee in this scenario (Figure 2.6). The rural areas and very small communities see very little change over the next forty years considering the very modest growth rates placed on them in the scenarios given the current land use regulation structure. While the exact spatial configuration of developed grid cells are likely unrealistic at the small scale (Figure 2.7), when taken at the scale of the landscape, early reviewers of the scenario maps agreed with their plausibility. Since the ultimate goal is to incorporate these maps into ecosystem service assessment scenarios at that scale, it can be argued they are sufficient. 

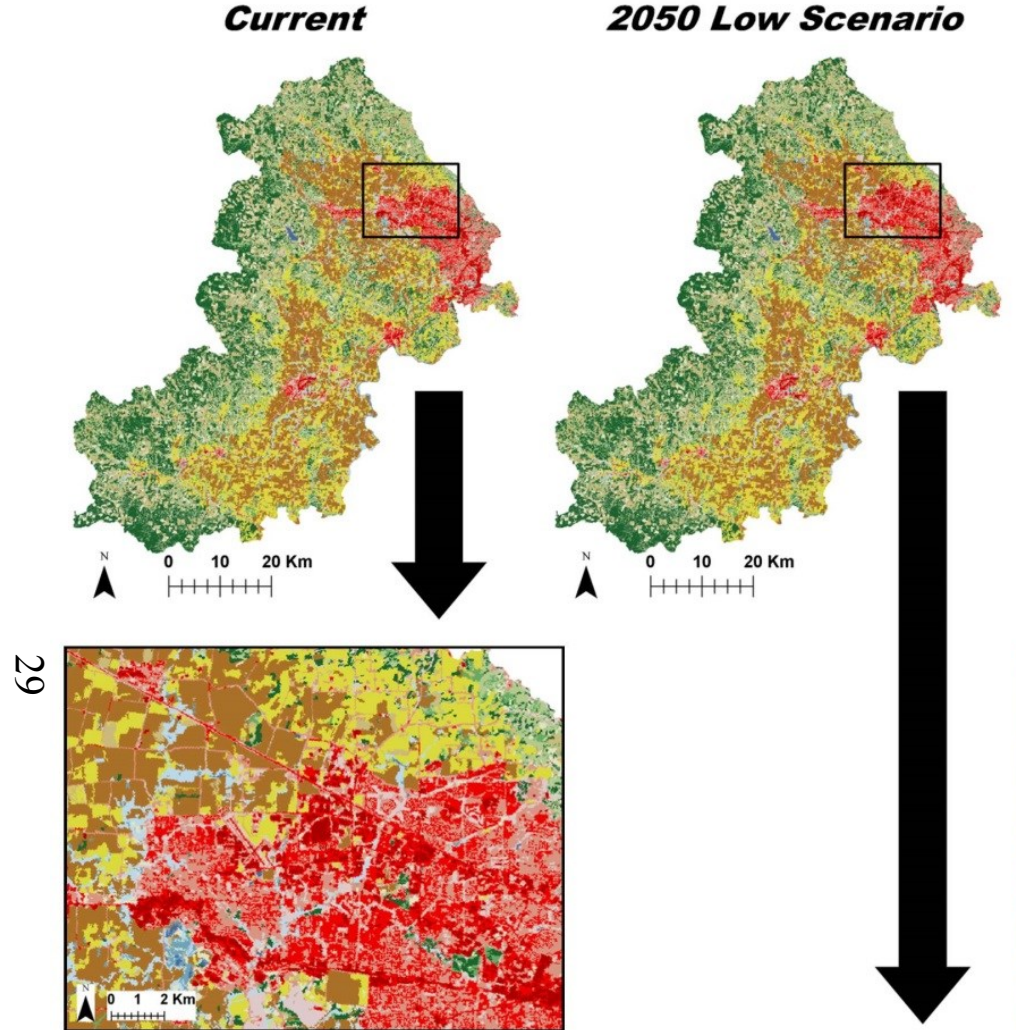

N $\quad 0 \quad 10 \quad 20 \mathrm{~K}$
2050 Medium Scenario
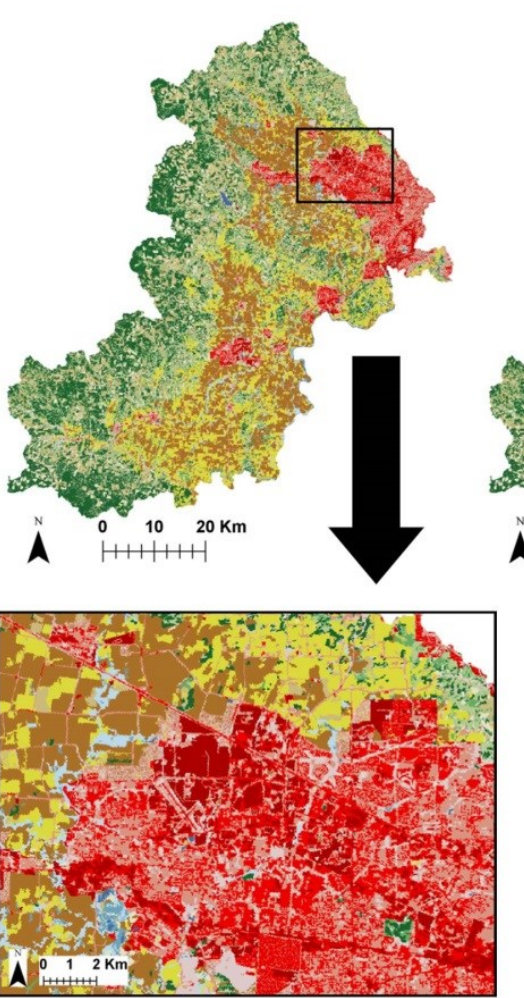

2050 High Scenario

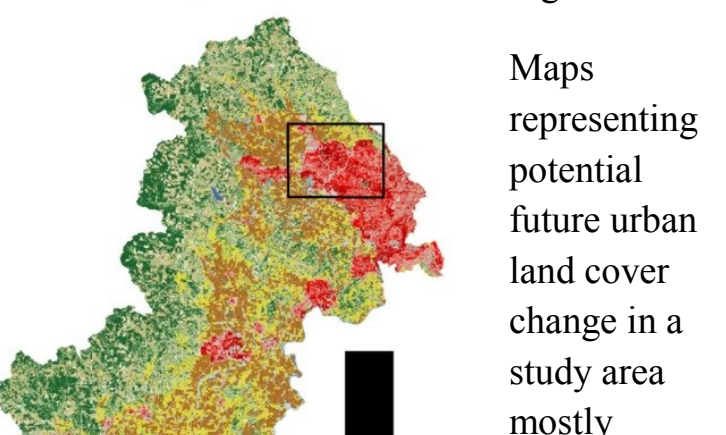

mostly

comprised

of the

Tualatin and

Yamhill

river basins.

The insets

represent a

portion of

the study

area

showing

growth

adjacent to

the city of

Hillsboro,

OR. 

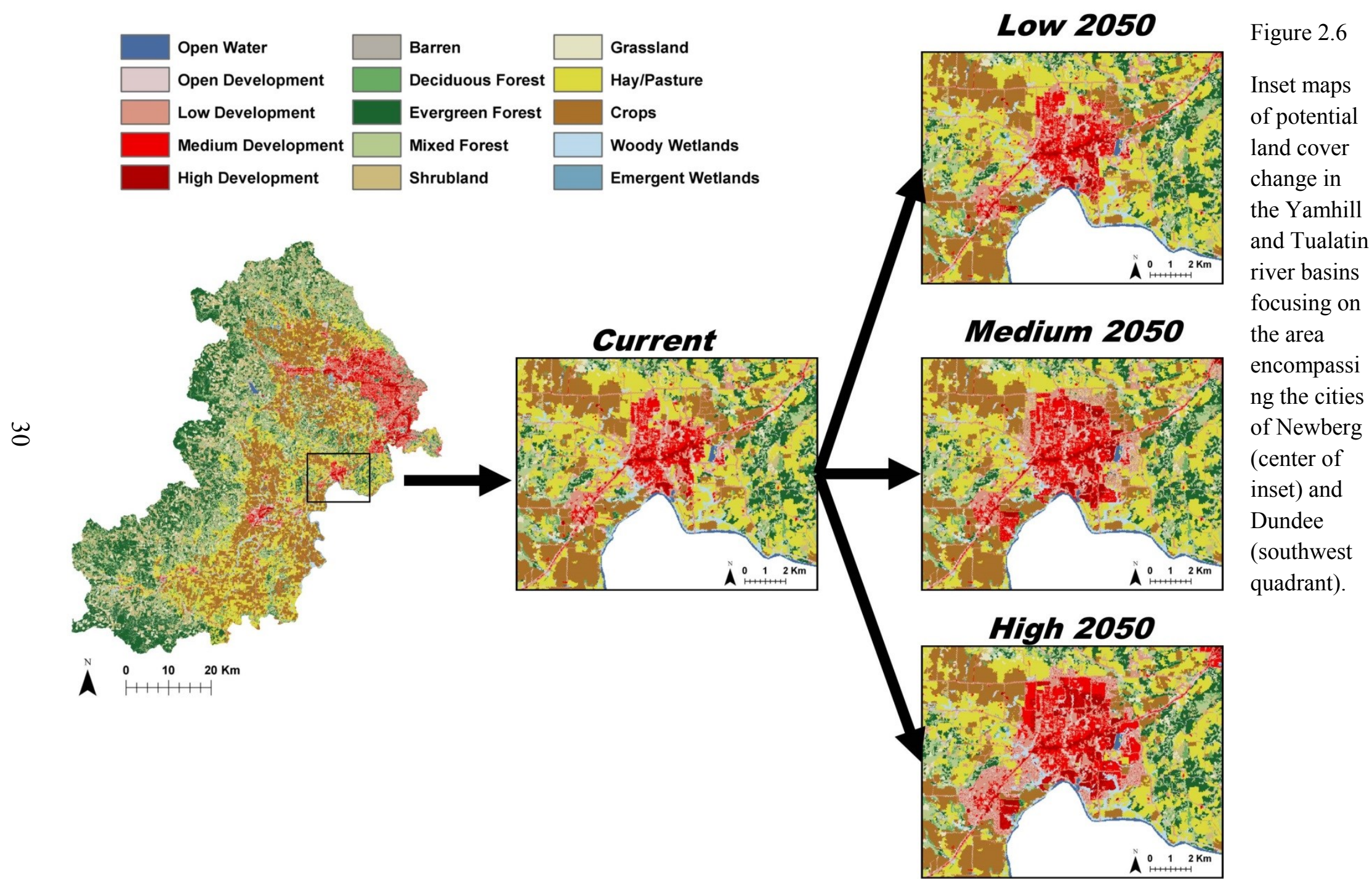


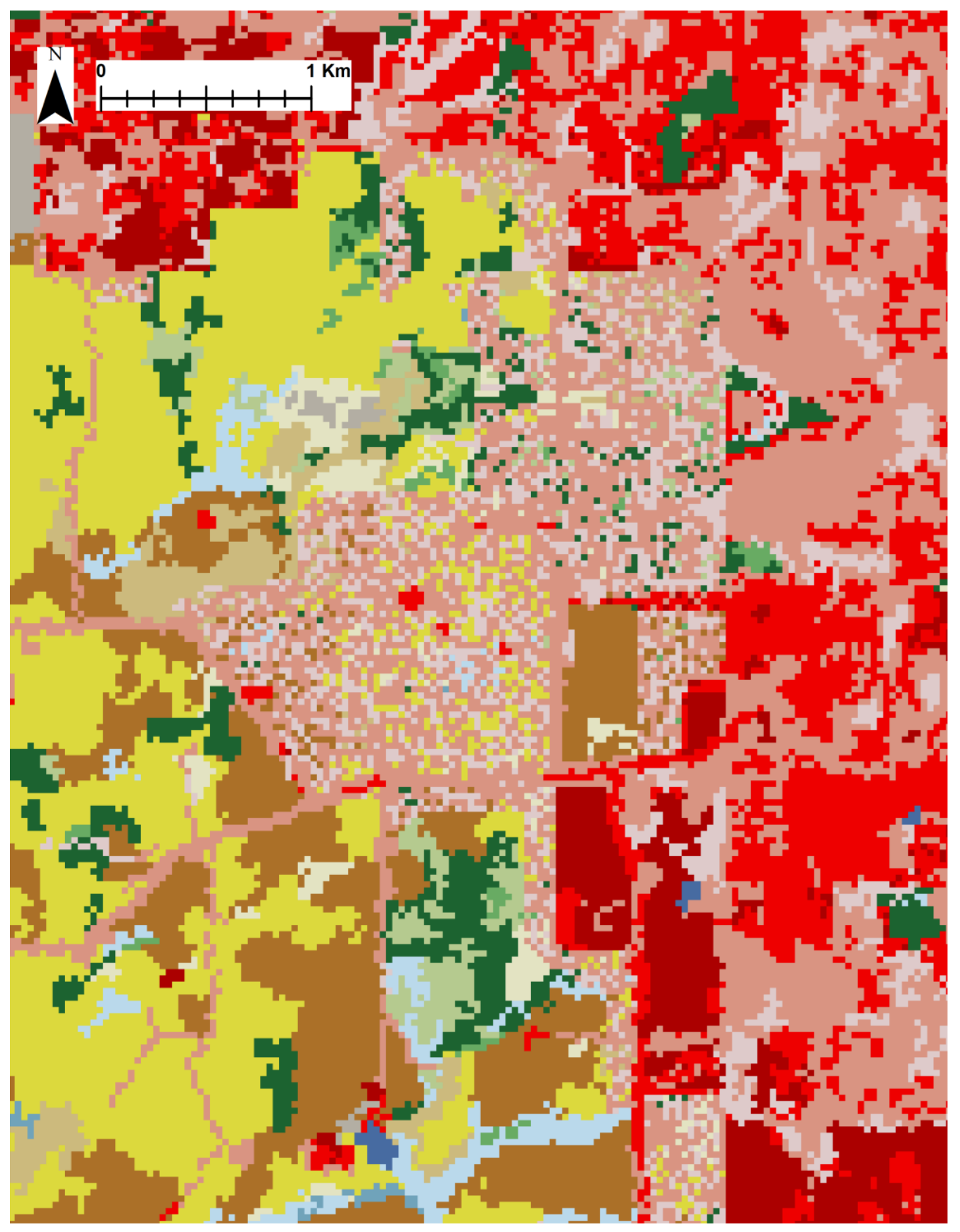

Figure 2.7

Example of grid cell raster mosaic phenomena occurring in maps depicting potential future land cover change. Exact arrangement of grid cells is determined randomly where there are more candidate pixels for transformation than are required. 


\section{Discussion}

Nature's benefits to humans are increasingly perceived as goods and services by the environmental policy community. Using this conceptual approach in real management decisions requires developing reliable methods for quantifying and mapping the biophysical indicators of these benefits (Crossman, Bryan, et al., 2013; Crossman, Burkhard, et al., 2013; Schägner et al., 2013). LULC maps remain integral to the development process. The method presented in this paper offers a simplified approach for producing future scenario land cover maps. The stakeholder guided mapping process allows for a place-specific analysis, potentially making it useful for a decision-relevant planning tool. Maps are often perceived as having an "air of authority" when in fact they are all produced with a set of assumptions that warrant a degree of caution in their interpretation (Hauck, Görg, Varjopuro, Ratamäki, Maes, et al., 2013). Here the method is transparent and the assumptions are simple. This can potentially lead to more communicability to laypersons and non-experts. Other modeling approaches like agentbased systems or cellular automata (Parker, Manson, Janssen, Hoffman, \& Deadman, 2003) may address complexity with more sophisticated assumptions, but also produces a more complex message to explain.

The engagement process used in the study was somewhat limited. Although small, the workshop members did represent a large cross-section of interests in how land use in our study area is managed. This meets the typical definition of a stakeholder in conservation planning (Koschke, Fürst, Frank, \& Makeschin, 2012). The effort lacked the time and resources necessary for a more complete gathering of stakeholder input even 
amongst the few that were consulted since urban issues dominated the conversation. Had various groups with differing perspectives been consulted over the course of a longer scoping process, more criteria could potentially be identified. This could have led to a fuller scenario spectrum. Therefore, this effort represents an initial step at modeling land cover in the study area, and further modifications and refinements of the model are warranted. Other data would likely be useful and perhaps provide the analysis nuance or at least provide an extra level of credibility. Transportation networks and roadways were not deemed overly relevant in the single committee meeting, but probably still could be an important driver of land cover change (Southworth et al., 2011). Given that affordable housing within UGBs are limited, transportation network could lead to growth spilling into other commutable portions of greater Portland like southern Washington, communities along the Columbia River north of Portland like Scappoose, and the Yamhill county cities of McMinnville and Newberg. Another concern is that the assumption of the effect of groundwater restriction zones on the study area. While it has real consequences in rural areas, since the vast majority of water use by urban lands in the region is surface water, it may not be a severe impediment (S. Kelly, personal communication, November 15, 2012). Infrastructure access variables (e.g., water, sewer, gas lines) have huge consequences on the location of development, but data access has proven difficult.

A few simple economic/demographic variables like population, household, and employment were used as way to develop scenarios, but they do not inform the specific placement of development on scenario maps. One member of the meeting later 
mentioned that this research implicitly assumes the demand for new development will be present. The dynamics of land supply are largely ignored and rather than incorporating projections of future market conditions, the model assumes that land consumption will occur as population grows. Econometric models based on assumptions of land owner decisions to maximize net returns from land can potentially address some of these issues (Radeloff et al., 2012; Suarez-Rubio, Lookingbill, \& Wainger, 2012).

As mentioned previously, the assumption of unchanging forest and agricultural land in the study area is large and unrealistic. Ecological considerations such as forest response to climate ranging from fire frequency to vegetation structure to transitions in species composition are beyond the scope of this analysis, but will have consequences on freshwater and terrestrial ecosystem services. However, since our time frame is shorter than the time some of these transformations to occur, vegetation response to climate change could be rather minimal and could thus be ignored. These issues are also compounded in complexity as resource management evolves and market drivers change in the production of forest products and food. One possibility would be to create a few simple assumptions about increase and decrease in the broad vegetation categories like forest/shrubland or pasture/row crops.

The case of Oregon benefits from a well-defined land use regulation structure. Much of the analysis to determine where development can occur has been performed by the local agencies responsible for defining the future urban reserves. The current UGBs and URAs encapsulate much of the variables discussed above. They are the key dataset for providing plausible results. Given that not all regions have a land use system like 
Oregon, a larger set of variables would probably be necessary to create scenario maps. With this in mind, the continuation of the present Oregon land use system is essential to the viability of the presented future land cover products. As it has been challenged by several ballot initiatives in the past, including the passage of measure 37 , its sustained future is far from a foregone conclusion and the consequences of the Measure 49 of land use have yet to be made visible. Its passage appears to have kept the system from implosion for now, but as both regional and national economic conditions change over time, new challenges to it will likely return. This may put it once again in jeopardy unless adaptive measures are taken that are politically palatable (Walker \& Hurley, 2011).

Land cover maps offer a useful input into models estimating the provision of a suite of ecosystem services. They do not have the capability of capturing the site-scale variation taking place in land parcels. Results of this mapping exercise and any subsequent ES assessment must be placed in a regional or landscape level context. The stakeholder workshop participants mentioned the potential for this mapping exercise not capturing the variability within land cover types. The findings are consistent with other stakeholder studies where for instance the differences in impacts from organic and industrial agriculture are perceived to provide differing levels of different types of ES (Hauck, Görg, Varjopuro, Ratamäki, \& Jax 2013). The scale at which these differences are present cannot be addressed in this study.

According to some stakeholders, the assumption that future urban land cover has the same biophysical characteristics as the current urban land cover in terms of ecosystem functions could be questionable. It is recognized that technology and development 
practices tied to urbanization will likely continue to improve especially when tied to regulations or innovative policies like market-based incentive programs such as payment for ecosystem services (PES) schemes (Jack, Kousky, \& Sims, 2008; Lockie, 2013). This can place current and future emphasis on "green" infrastructure (GI) projects or best management practices (BMPs) like green roofs (Orbendorfer et al., 2007). These GI or BMPs can reduce effective imperviousness in urban watersheds to promote healthy ecologically functioning streams (Booth, Hartley, \& Jackson, 2002; Holman-Dodds, Bradley, \& Potter, 2003; Walsh, Fletcher, \& Ladsen, 2005). The response to these on the ground has the potential to transform all or parts of the urban fabric, making convenient categorization of land types all the more difficult to define. This is an important caveat when using any future land cover projection.

\section{Conclusions}

As the idea of defining natural processes as ecosystem services that provide a multitude of benefits to humans gains more steam in acceptance into the mainstream, reliable means of quantifying and mapping them will be essential if the approach is to make the leap to actual environmental management practice. This step is important for assessing current ES levels and gauging the efficacy of conservation efforts like ES credit markets or PES schemes. Constructing future scenarios further aids the process by offering possible impacts to different outcomes. An important component to both of these steps is land use/land cover (LULC) maps. They allow for a spatially explicit analysis and can accommodate future changes using GIS techniques. The method described above 
creates a series of LULC maps that represent potential future for a growing region following a method borrowing from the procedure presented in Swetnam et al. (2011). It is informed by stakeholder knowledge and perceptions that lend plausibility to the depiction of future landscapes.

The Oregon land use system in place in this study area allows projections with well-defined placement and limits to urban growth. These regulations are inherently political and have been seriously challenged in the past. The fact that LULC maps generalize a landscape and obscure small scale effects should highlight the need to interpret results from a landscape or regional standpoint. Land cover classes in the future may be even more difficult to generalize because of the possibility of improvements in technology and infrastructure from an ecological standpoint (e.g., best management practices that will lower urban impacts on ecohydrological processes). Despite some inherent limitations, it offers a fairly approachable way to "sketch" what the landscape may look like based on possible future paths without heavily relying on computationally intensive land cover modeling. Scenarios can be produced without much time and resources and thus offer a potentially useful planning tool. 
III. Assessment of freshwater ecosystem services in the Tualatin and Yamhill basins under climate and land cover change

\begin{abstract}
The ecosystem services (ES) concept continues to move towards the mainstream of environmental policy and management. There are still many challenges associated with using it as approach. One objective is how to develop reliable methods of quantifying and mapping ES. Additionally, ecosystems are subject to change of which two main drivers are land use/land cover (LULC) and climate change. We use the ES modeling tool Integrated Valuation of Environmental Services and Tradeoffs (InVEST) to estimate and map the provision of freshwater ES at the sub-watershed scale for the Tualatin and Yamhill basins of northwestern, Oregon. We investigate this under a series of LULC and climate change scenarios centered on the year 2050 with three of each ranging from low to high growth. Results suggest that the service of water yield is much more sensitive to climate change rather than LULC change, and the lowland areas of the study area will see more change from current to future conditions than the uplands. InVEST's nutrient retention estimates are correlated to its export estimates in the water purification model. Change is almost exclusively land cover driven with an increase in exports due to increased urbanization in the Tualatin. The Yamhill basin sees decreases in exports from urbanization because agriculture land cover is parameterized for much higher nutrient exports. Sediment exports will increase throughout the study area mostly due to higher erosivity rates from higher winter rainfall. Higher exports translate to higher retention rates as well. InVEST models are simple conceptually, and contain only
\end{abstract}


two to three parameters for each model. Parameter sensitivity and their user-defined nature lead to uncertainty in outputs. Other issues leading to uncertainty in InVEST are also discussed. InVEST has more utility as a landscape planning tool than providing information about specific management targets in water quality. One general result of this study indicates that the Yamhill basin provides a higher level of freshwater ES than the Tualatin, and restoration efforts in the Yamhill basin would have a greater effect than those in the Tualatin basin in improving water quality downstream in the larger Willamette system. The estimated relative changes in ES provision are still valuable for a tradeoff or prioritization study. This research represents a first step in a full evaluation of ES in the study area. 


\section{Introduction}

Nature provides a number of benefits essential to humanity's well-being. The ecosystem services (ES) concept argues that this is fundamental and needs to be more fully acknowledged in decision-making. There should also be ways to recognize and state their full value (Costanza et al., 1997; Daily, 1997; de Groot, Wilson, \& Boumans, 2002). An early observation in the development of ES thinking was that supplies of and demands on ES are spatially explicit and must be quantified in a spatially explicit manner (Eade \& Moran, 1996; Troy \& Wilson, 2006). A major objective in towards mainstreaming it for policy and management is developing reliable techniques of quantifying and mapping ES (Burkhard et al., 2012). Researchers have presented several methods for presenting the spatial distribution of ES (Chan, Shaw, Cameron, Underwood, \& Daily, 2006; Egoh et al., 2008; Raudsepp-Hearne, Peterson, \& Bennet, 2010). These methods can vary widely, and it is argued that common mapping techniques are essential to provide the transparency and repeatability necessary for management integration (Crossman, Burkhard, et al., 2013; Martínez-Harms \& Balvanera, 2012). Others in the ES community debate what types of market based policy instruments like credit markets or payments for ecosystem services (PES) schemes are most effective for conserving and enhancing ES (Jack, Kousky, \& Sims, 2008). Any one of these systems will need to rely on trustworthy and transparent biophysical estimates. The next step is the link of the biophysical and the economic. Currently, the proposed method to do this is through the use of an ecological production function that calculates the "output" or production of an ecosystem. This production is specified in a common unit that gives a tractable way to 
proceed with an economic valuation, and accounts for spatial heterogeneity more effectively than the common benefit transfer valuation approach (Tallis \& Polasky, 2009).

ES variability occurs in time as well as space. Shifts in the pattern and makeup of land use over time have consequences to the amount and location of ES on the landscape (Lautenbach, Kegel, Lausch, \& Seppelt, 2011). Another important ES related research question is how the provision of ES will change in an uncertain future? Scenario analysis is seen as a method of evaluating possible futures, and is now used in environmental studies (Peterson, Cumming, \& Carpenter, 2003; Thompson et al., 2012). The spatially explicit ES modeling environment Integrated Valuation of Environmental Services and Tradeoffs (InVEST) (Tallis et al., 2013) offers the ability to evaluate scenarios given data availability. It does so using simple ecological production functions. Its developer, the Natural Capital Project (www.naturalcapitalproject.org) has been using it in a variety of conservations settings around the globe (Ruckelshaus et al., 2013). Several studies in the literature have used InVEST for ES assessment (Table 3.1). Thus far, scenario analyses with InVEST have used LULC as the ES change driver (Goldstein et al., 2010; Nelson et al., 2009; Nelson et al., 2010; Polasky, Nelson, Pennington, \& Johnson, 2011). Fewer studies assessing future ES have incorporated climate (Bateman et al., 2013), and only one so far investigating climate impacts with InVEST (Terrado, Anuña, Ennaanay, \& Sabater, 2013). The focus of our study is water-related ES that are in particular highly sensitive to future climatic conditions. 
We evaluate water-related ES using the InVEST freshwater toolset for two adjacent river basins in northwest Oregon. We investigate the following questions relevant to ES research.

(1) What are the estimated changes in freshwater ES in the future relative to current estimates under the two main change drivers, namely climate and LULC? Which driver is more influential in determining future shifts in each ES?

(2) What is the spatial distribution of freshwater ES currently and how might it change under the above mentioned drivers? We produce maps of these changes to answer this question.

(3) Finally, through the process of our analysis we provide comments on the usefulness and caveats of InVEST's freshwater components. The ultimate question this work addresses is whether it provides useful information to the ecologically-based management of the study area? 
Table 3.1

Summary of a selection of studies using Integrated Valuation of Environmental Services and Tradeoffs (InVEST) in the academic literature.

\begin{tabular}{|c|c|c|c|}
\hline Authors & Study Area & Services Evaluated & Key Findings/Comments \\
\hline $\begin{array}{l}\text { Nelson et al. } \\
(2009)\end{array}$ & $\begin{array}{l}\text { Willamette } \\
\text { River Basin } \\
\text { (Oregon, } \\
\text { U.S.A.) }\end{array}$ & $\begin{array}{l}\text { Water Quality, Soil } \\
\text { Conservation, Storm } \\
\text { Peak Management, } \\
\text { Carbon Sequestration, } \\
\text { Biodiversity, } \\
\text { Commodity } \\
\text { Production }\end{array}$ & $\begin{array}{l}\text { Study used early forms of InVEST } \\
\text { models. Many are not part of the } \\
\text { current available toolset. Of three } \\
\text { scenarios assessed, the conservation } \\
\text { LULC outperformed the status quo and } \\
\text { plan trend LULC scenarios except for } \\
\text { commodities production. The biggest } \\
\text { gains were in water quality. ES were } \\
\text { not estimated in biophysical terms only. } \\
\text { Climate change was not considered. }\end{array}$ \\
\hline $\begin{array}{l}\text { Nelson et al. } \\
(2010)\end{array}$ & Global & $\begin{array}{l}\text { Crop Production, } \\
\text { Water Availability, } \\
\text { Carbon Storage, } \\
\text { Habitat for Species }\end{array}$ & $\begin{array}{l}\text { InVEST crop production currently } \\
\text { unavailable in current toolset. Two } \\
\text { scenarios are based on cropland areal } \\
\text { increase and efficiency. In both cases } \\
\text { tradeoffs of ES and habitat occur with } \\
\text { crop production. It is mitigated in one } \\
\text { scenario where crop efficiency requires } \\
\text { less undeveloped land conversion. }\end{array}$ \\
\hline $\begin{array}{l}\text { Polasky, } \\
\text { Nelson, } \\
\text { Pennington, \& } \\
\text { Johnson } \\
\text { (2011) }\end{array}$ & $\begin{array}{l}\text { Minnesota, } \\
\text { U.S.A. }\end{array}$ & $\begin{array}{l}\text { Habitat Quality, } \\
\text { Carbon Sequestration, } \\
\text { Water Quality, } \\
\text { Agriculture } \\
\text { Production, Timber } \\
\text { Production, Urban } \\
\text { Development }\end{array}$ & $\begin{array}{l}\text { Several models mentioned in article are } \\
\text { not part of InVEST toolset. Scenarios } \\
\text { suggest tradeoffs between private } \\
\text { returns (increase with more agriculture } \\
\text { LULC) and social benefits (increase } \\
\text { with forestry and conservation } \\
\text { scenarios). ES were monetized in this } \\
\text { study. Climate change was not } \\
\text { considered. }\end{array}$ \\
\hline $\begin{array}{l}\text { Bai, Zhuang, } \\
\text { Ouyang, } \\
\text { Zheng, \& } \\
\text { Jiang (2011) }\end{array}$ & $\begin{array}{l}\text { Baiyangdian } \\
\text { watershed } \\
\text { (north China } \\
\text { plain) }\end{array}$ & $\begin{array}{l}\text { Habitat Quality, } \\
\text { Carbon Sequestration, } \\
\text { Water Yield, Nutrient } \\
\text { Retention, Sediment } \\
\text { Retention, Pollination }\end{array}$ & $\begin{array}{l}\text { Investigated spatial congruity among } \\
\text { biodiversity and ES. Quality habitat for } \\
\text { biodiversity was correlated to water } \\
\text { yield, sediment retention, and carbon } \\
\text { sequestration. Nutrient retention and } \\
\text { pollination did not occur with quality } \\
\text { habitat. }\end{array}$ \\
\hline $\begin{array}{l}\text { Goldstein et } \\
\text { al. (2012) }\end{array}$ & $\begin{array}{l}\text { Kamehameha } \\
\text { School Land } \\
\text { Holdings } \\
\text { (North Shore, } \\
\text { Oahu, Hawaii, } \\
\text { U.S.A.) }\end{array}$ & $\begin{array}{l}\text { Carbon Storage, Water } \\
\text { Quality, Financial } \\
\text { Returns from Land } \\
\text { Base }\end{array}$ & $\begin{array}{l}\text { Estimated net returns of land based on } \\
\text { different land use scenarios as well as } \\
\text { net differences of ES based on status } \\
\text { quo. Aided the decision-making of the } \\
\text { institution responsible for land } \\
\text { management. }\end{array}$ \\
\hline $\begin{array}{l}\text { Terrado, } \\
\text { Acuña, } \\
\text { Ennaanay, } \\
\text { Tallis, \& } \\
\text { Sabater } \\
(2013)\end{array}$ & $\begin{array}{l}\text { Llobregat River } \\
\text { Basin } \\
\text { (Catalonia, NE } \\
\text { Spain) }\end{array}$ & $\begin{array}{l}\text { Water Yield, Nutrient } \\
\text { Retention, Sediment } \\
\text { Retention }\end{array}$ & $\begin{array}{l}\text { InVEST freshwater models were used } \\
\text { to compared average years to wet and } \\
\text { dry years. Estimated nutrient retention } \\
\text { changed little between these conditions } \\
\text { but the benefit increased during dry } \\
\text { years. Sediment retention was more } \\
\text { sensitive to climatic conditions. Its } \\
\text { benefit increased during wet years. }\end{array}$ \\
\hline
\end{tabular}




\section{Methods}

We use the InVEST freshwater models to assess the freshwater ES of water yield, purification, and sediment retention in two sub-basins in the Willamette River basin of Oregon. We use field data from the study area to calibrate the parameterization of InVEST. The calibrated InVEST models are then used in a series of scenarios that incorporate both land cover and climate change to produce a set of maps depicting freshwater ES in our study area. InVEST has the potential to be the standardized toolset that several scholars have called necessary for using the ES framework in policy and management.

\section{A. Study Area}

Draining the northwestern Willamette valley, the Tualatin and Yamhill basins are 1,844 and 2,000 square kilometers, respectively (Figure 3.1). Both basin headwaters are in the Oregon Coast Range in the western/southwestern portions of the study area. The Yamhill basin is historically wetter than the Tualatin. The southern fork of the Yamhill, at approximately three-quarters (1350 sq. km) the area of the whole Tualatin, yielded 982 mm of water annually on average than the Tualatin's $659 \mathrm{~mm}$ from 2001 to 2010 (NWIS, 2013). The landscape of the area falls into three broad categories of upland forests, valley floors dominated by agriculture, and urban land. 


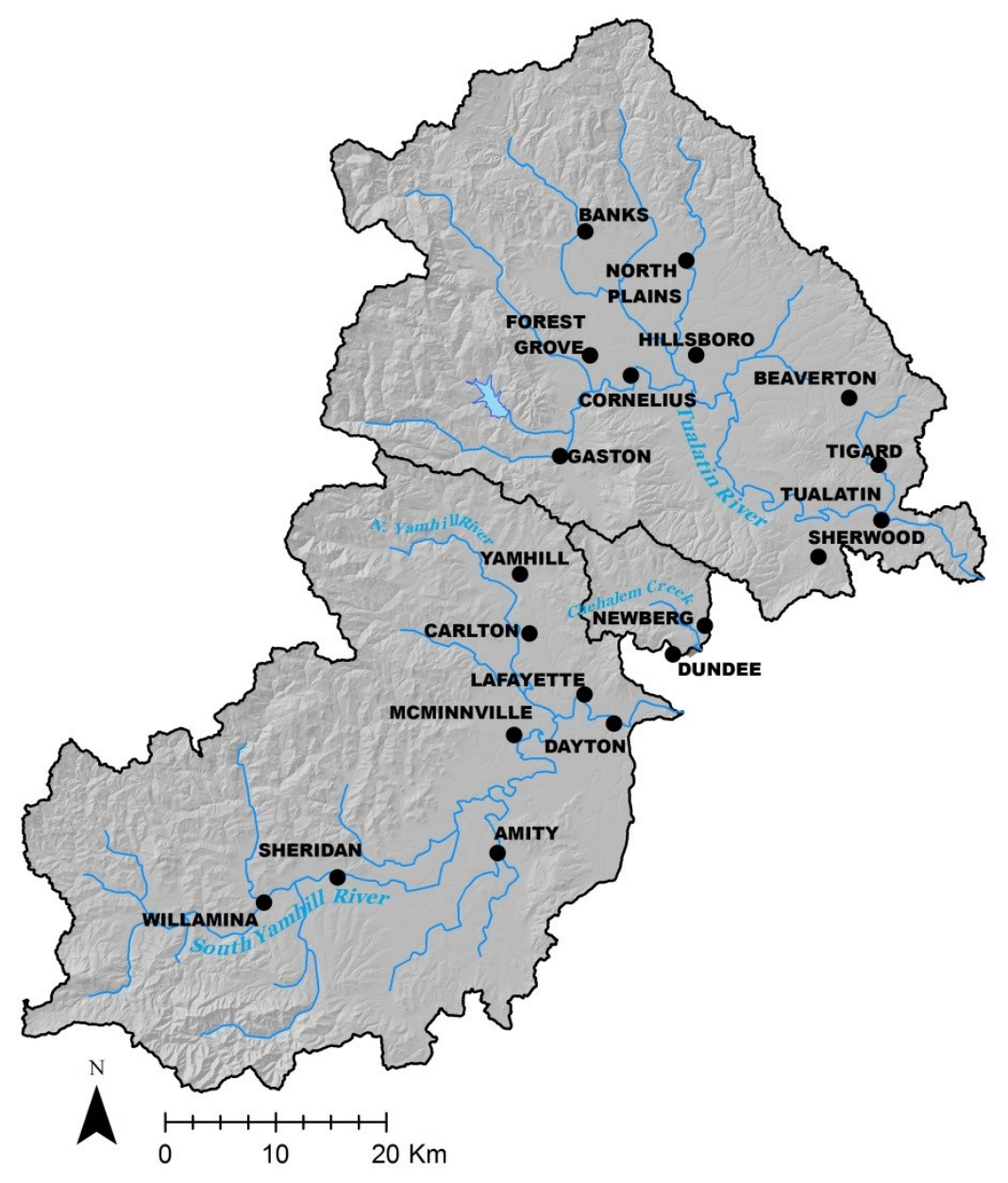

Figure 3.1

Study Area - The Tualatin and Yamhill River Basins and the interstitial Chehalem Creek watershed.

Both river systems have reaches defined as impaired and subject to total maximum daily loads (TMDLs) for several water quality indicators under the Clean Water Act (ODEQ, 2012). The Tualatin currently has TMDLs in place for $\mathrm{pH}$, dissolved oxygen, total phosphorus, and ammonia since 1988 due to lower reaches of the river having historic issues with algal growth and eutrophication. This is partly caused by the legacy effects of rapid urbanization outstripping treatment capacity and the slow moving low gradient nature of the main-stem on the valley floor. Additionally, a large portion of 
the basin is agricultural and contributes to non-point sources of pollutants. Compounding this is the high levels of phosphorus in basin soils leading to high baseline export (Abrams \& Jarrell, 1995; Kelly, Lynch, \& Rounds, 1999). Water quality issues in these basins contribute to the problems facing the greater Willamette Basin River system which has TMDLS focused on bacteria, mercury, and temperature (ODEQ, 2006). As the public and regulators become more sensitive to water quality parameters affecting aquatic biota, especially of the culturally and economically important native salmonids, temperature TMDLs are in the process of being developed in Oregon with the waterways in the study area being of primary concern. Although problems persist, water quality in the area has improved significantly over the last 50 years in the lower basin. Much of this improvement has come with the cooperation of the wastewater management agencies in the study area updating and upgrading the technology of their treatment plants (ODEQ, 2012). The Tualatin TMDL has recently been amended to account for planned need to increase treatment capacity so all plants in the basin can contribute to loadings during the low-flow summer months. The impetus is in anticipation of regional population growth over the next several decades. Climate change and increased urbanization thus have potential deleterious effects on the biological integrity of these river systems, as increasing temperature and nutrient loads further degrade dissolved oxygen levels necessary for a healthy aquatic system (Chang \& Lawler, 2011). Additionally, communities in the study area rely on these basins for drinking water supplies (ODEQ, 2013). This may place increased demands on wastewater and stormwater infrastructure as mangers struggle to respond. Services provided by the landscape like water purification 
may have potential to mitigate some of these effects and reduce the burden of built infrastructure. There is already a precedent occurring in the Tualatin River basin where land owner incentives have led to the enhancement of the ES of thermal shading through riparian restoration (Cochran \& Logue, 2011). In addition to shade, natural vegetation has the capacity to filter contaminants, excess nutrients, and mobilized sediments (Brauman, Daily, Duarte, \& Mooney, 2007). The analysis incorporates this effect with a landscape level simulation of restored riparian buffer strips.

\section{B. Calibration}

To reduce uncertainty in the modeling effort and scenario analysis, the InVEST models were calibrated to empirically derived estimates of water yield, total nitrogen, total phosphorus, and total suspended sediment. Calibrations were performed at nine locations for several time periods within the full historical study period of 1981 to 2010 . Daily flow records at eight stations and water quality samples at four stations were gathered from several gauged sub-watersheds in the study area (Appendix B, Table B.1 and Figure B.1). Daily mean runoff was aggregated to an average annual yield (mm) for InVEST water yield calibration. Both flow and grab sample of concentration were used to estimate average annual stream export loads. Samples were taken on a weekly schedule, but gaps do occur in the records for some gauges. The load estimates were produced in the estimator program LOADEST (Runkel, Crawford, \& Cohn, 2004) from the United States Geological Survey (USGS). The Yamhill did not have a water quality sampling station located at a flow gauge. Instead, we used simulated daily runoff from the 
hydrologic model Soil and Water Assessment Tool (SWAT) (Arnold et al., 2012). We also developed approximate estimates of export loads from the main known point sources in the study area, wastewater treatments plants. These were subtracted from the total load estimates in order to isolate the landscape non-point contributions to stream exports. We adjusted InVEST outputs to these final estimates. Since the decade from 2001 to 2010 contains the most data with several sub-watersheds available for calibration unavailable earlier in the full study period, InVEST was calibrated to this time period for the Tualatin basin. Model parameters were adjusted at the same rate across all land cover types to produce a calibration for the entire study period. The Yamhill basin parameterized for data from 1996 to 2010, nearly the full available data record.

\section{Spatial Data}

InVEST models require several types of spatially explicit biophysical data that can be introduced and manipulated in a Geographic Information System (GIS) environment. We manipulated and processed data as well as ran most InVEST tools in ArcGIS 10.1 (ESRI, 2012). Each biophysical component of InVEST requires its own set of variables, but several are common among the three freshwater components (Table 3.2). We used historical and current LULC and climate data for InVEST calibration. Several sets of climate and land cover data were employed for future scenarios. Other data like soil characteristics and topography remain unchanged in the scenario analysis. InVEST recommends output aggregation. The modeling structure is not equipped to handle finescale interpretation of the results. For this study, model outputs were summarized to 
SWAT delineated watersheds aggregated to be approximately analogous to a 12-digit USGS Hydrologic Unit Code (HUC) watershed. This unit scale of analysis was chosen for practicality related to other facets of the project, but also provides a level of spatial detail allowing for differentiation of ES characteristics in the study area. Although for the water yield model, we had success modeling at a smaller spatial unit, we do not have data to calibrate at a smaller unit for nutrients and sediments. Thus, we feel that we can only be confident in our result at this or a larger spatial unit for nutrients and sediments. Furthermore, the smallest calibrated sub-watershed, Fanno Creek (Appendix B, Figure B.1), is roughly analogous to the 12-digit HUC.

A land use/land cover (LULC) map is required by all three InVEST freshwater models - water yield, nutrient retention, and sediment retention. They are parameterized on its land cover categories using the USGS National Land Cover Dataset (NLCD) 2006 (Fry et al., 2011). At fifteen cover types, it provides differentiation without overwhelming the parameterization effort. The scenario LULC data were derived from NLCD 2006 using a simple land change model based on stakeholder identified criteria (See Chapter II). This model only focused on urban growth. In order to test InVEST's response to a landscape scale change in vegetation management, we simulated a thirty meter strip of riparian vegetation along streams in the study area that meet two criteria. They are on privately held land and they are not in area that is already urbanized. Although we do anticipate restoration in current urban lands, we assume that these will be targeted and will not always register relative to NLCD's resolution (30m x 30m pixels). 
The water yield model requires two climate variables, precipitation and potential evapotranspiration (PET). Four kilometer resolution climate data were obtained from the University of Idaho's Gridded Surface Meteorological Data (METDATA) program. For calibration, a historic dataset combining spatial and temporal attributes from several sources (Abatzaglou, 2013) was used. For future scenarios, three global climate models (GCMs) were selected for use with InVEST that are included in phase five of the Climate Model Intercomparison Project (CMIP5) (Taylor, Stouffer, \& Meehl, 2012). Data was downscaled using the multivariate adapted constructed analogs (MACA) method (Abatzoglou \& Brown, 2012). They were chosen to provide a low, medium, and high range of potential climate outcomes for our study area (Figures 3.2- 3.4). The future period was set at 2036 to 2065 in order to center the scenario at 2050 , forty years from the end of our historic period. InVEST modeling took place at both periods with each model in order to calculate a percent change in ES provision within each scenario.

InVEST sediment retention requires rainfall erosivity as a parameter. For calibration, a rasterized isomap of erosivity published by the US Department of Agriculture (Renard, Foster, Weesies, McCool, \& Yoder, 1997) and digitized by the InVEST development group was used. There is no ready-made erosivity product for future climate scenarios. Renard \& Freidmund (1994) developed a set of equations that statistically describe the relationship between erosivity and annual average precipitation as well as erosivity and a modified Fournier coefficient, an index based on monthly average precipitation and average annual precipitation. Nearing (2001) used their equations to project erosivity for the United States using several GCMs. We follow 
Nearing's approach here and use our scenario GCM's precipitation data to derive erosivity. The Fournier coefficient method provided comparable results to the calibration dataset and was used for the scenario analysis. (See Appendix B for additional information) 
Table 3.2

Data Requirements and Sources for the InVEST Freshwater Models. A - Water Yield, B - Water Purification, C - Sediment Retention

\begin{tabular}{|c|c|c|c|}
\hline Data Type & $\begin{array}{l}\text { InVEST } \\
\text { Model }\end{array}$ & Source & Description \\
\hline $\begin{array}{l}\text { Annual Average } \\
\text { Precipitation }\end{array}$ & $\mathrm{A}$ & $\begin{array}{l}\text { University of Idaho } \\
\text { Gridded Surface Meteorological } \\
\text { Data (METDATA) }\end{array}$ & $\begin{array}{l}\text { Thirty years of daily downscaled data summed to the annual scale and then } \\
\text { averaged over the time periods } 1981-2010 \text { and } 2036-2065 \text {. Resolution is } \\
0.041667 \text { decimal degrees }(4 \mathrm{~km} \times 4 \mathrm{~km}) \text {. }\end{array}$ \\
\hline $\begin{array}{l}\text { Potential or } \\
\text { Reference } \\
\text { Evapotranspiration }\end{array}$ & A & $\begin{array}{l}\text { University of Idaho } \\
\text { METDATA }\end{array}$ & $\begin{array}{l}\text { See Above. Daily data for minimum/maximum temperature and solar radiation } \\
\text { were averaged to the monthly scale for calculation of reference evapotranspiration } \\
\text { using the Hargreaves method. }\end{array}$ \\
\hline Soil Depth & $\mathrm{A}$ & $\begin{array}{l}\text { USDA Natural Resource } \\
\text { Conservation Service (NRCS) } \\
\text { State Soil Geographic Database } \\
\text { (STATSGO) }\end{array}$ & $\begin{array}{l}\text { Maximum soil depth was set to } 7000 \mathrm{~mm} \text {. Polygons converted to } 500 \mathrm{~m} \text { x } 500 \mathrm{~m} \\
\text { raster dataset. }\end{array}$ \\
\hline $\begin{array}{l}\text { Plant Available } \\
\text { Water Content }\end{array}$ & A & USDA NRCS STATSGO & $\begin{array}{l}\text { The fraction of water in soil that is available to plants. Polygons converted to } 500 \mathrm{~m} \\
\text { x } 500 \mathrm{~m} \text { raster dataset. }\end{array}$ \\
\hline $\begin{array}{l}\text { Land Use/Land } \\
\text { Cover }\end{array}$ & $\mathrm{A}, \mathrm{B}, \mathrm{C}$ & $\begin{array}{l}\text { USGS National Land Cover } \\
\text { Database (NLCD) } 2006\end{array}$ & $\begin{array}{l}\text { Standard national land cover product for the contiguous United States. Study areas } \\
\text { contain } 15 \text { land cover categories. }\end{array}$ \\
\hline Watershed Polygons & $\mathrm{A}, \mathrm{B}, \mathrm{C}$ & Derived from DEM & $\begin{array}{l}\text { Calibration polygons delineated using Arc Hydro (ESRI, 2012) from National } \\
\text { Elevation Dataset (NED) 30m DEM. Scenario and calibration foe sediment } \\
\text { retention polygons delineated in Soil and Water Assessment Tool (SWAT). }\end{array}$ \\
\hline Water Yield & $\mathrm{B}$ & InVEST Water Yield Model & Non-aggregated raster of water yield $(\mathrm{mm})$. \\
\hline $\begin{array}{l}\text { Digital Elevation } \\
\text { Model (DEM) }\end{array}$ & $\mathrm{B}, \mathrm{C}$ & NED 2004 DEM & $\begin{array}{l}\text { Hydrologically conditioned using National Hydrography Dataset (NHD) Plus } \\
\text { version } 1 \text { stream layer. } 30 \text { m resolution. }\end{array}$ \\
\hline Rainfall Erosivity & $\mathrm{C}$ & $\begin{array}{l}\text { USDA Isorodent Map of the US } \\
\text { (digitized by Natural Capital) }\end{array}$ & $\begin{array}{l}\text { Erosion potential due to kinetic energy of rainfall. } \\
(\mathrm{MJ} \mathrm{mm} / \mathrm{ha} \mathrm{h} \mathrm{yr)}\end{array}$ \\
\hline Soil Erodibility & $\mathrm{C}$ & USDA NRCS STATSGO & $\begin{array}{l}\text { K-factor is soil's susceptibility to detachment and transport by rainfall. } \\
\text { (MT ha h/ha MJ mm) }\end{array}$ \\
\hline
\end{tabular}



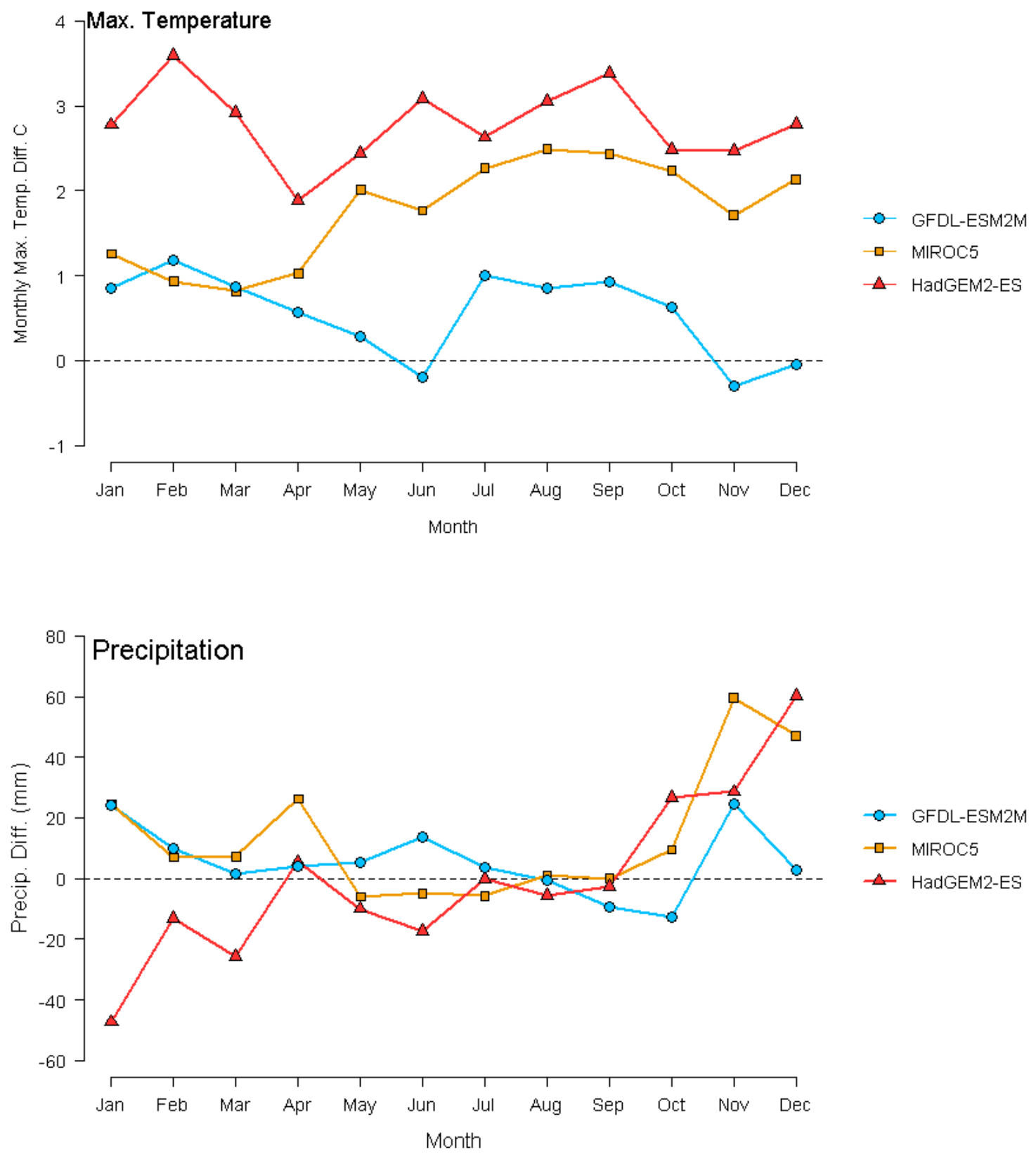

Figure 3.2

Differences in daily maximum temperature averaged by month and average monthly precipitation for the climate datasets in the scenario analysis for assessing water-related ecosystem services in the Tualatin and Yamhill Basin study area for three downscaled climate models. GFDL-ESM2M, MIROC5, and HadGEM2-ES represent the low, medium, and high climate change scenarios respectively. Baseline period is $1981-2010$ and future period is $2036-2065$. 


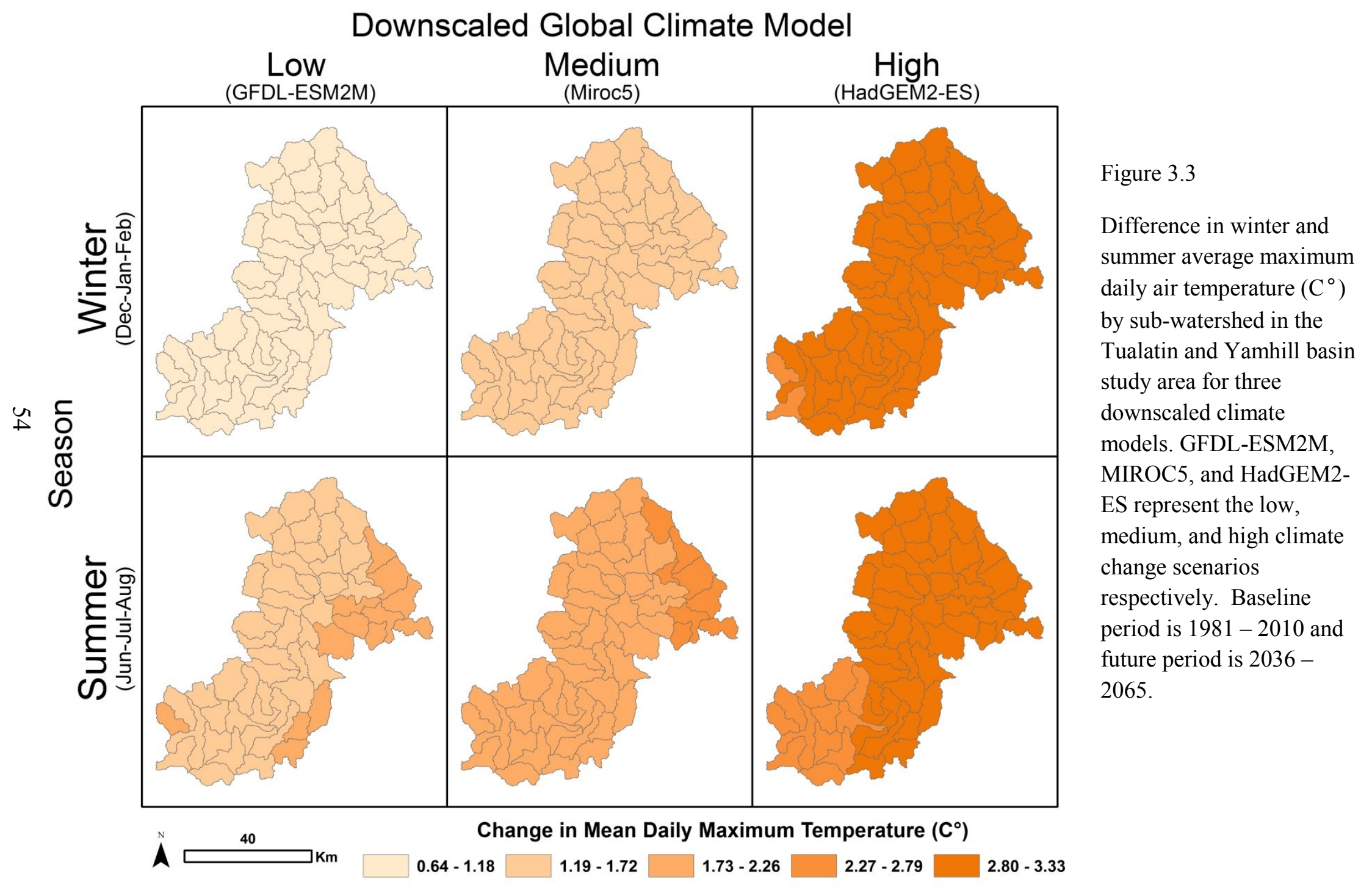




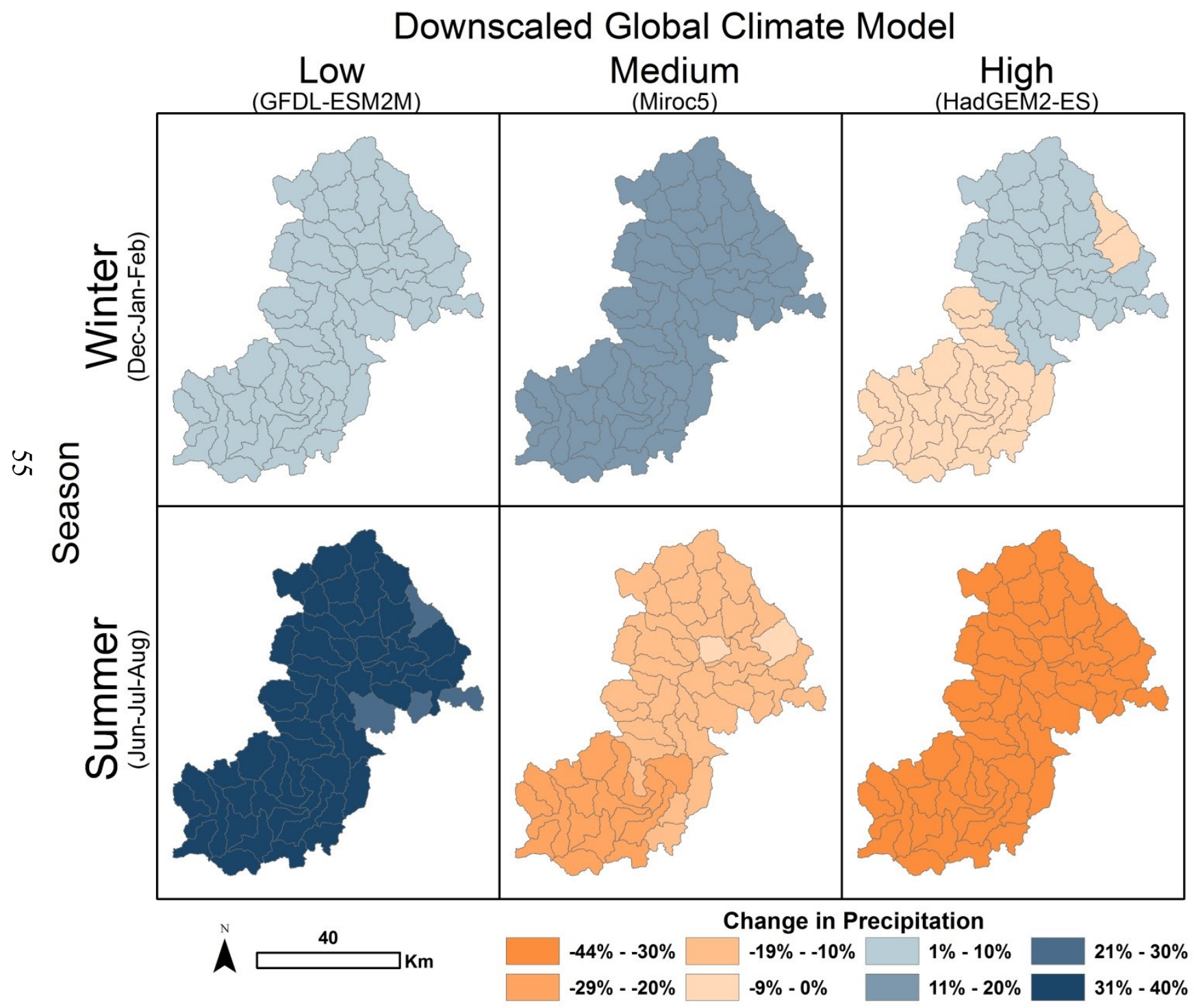

Figure 3.4

Percent difference in winter and summer precipitation ( $\mathrm{mm}$ ) by subwatershed in the Tualatin and Yamhill basin study area for three downscaled climate models. GFDLESM2M, MIROC5, and HadGEM2-ES represent the low, medium, and high climate change scenarios respectively. Baseline period is $1981-2010$ and future period is 2036 2065. 


\section{InVEST Freshwater Models}

Integrated Valuation of Environmental Service and Tradeoffs (InVEST) is an ES modeling toolset implemented in a GIS environment. It was developed by the Natural Capital Project, a partnership of several non-profit groups and academic institutions (www.naturalcapitalproject.org). Detailed descriptions of the various InVEST modules are provided in Tallis et al. (2013). Here we provide short descriptions of the three freshwater models used in the analysis, water yield, water purification, and sediment retention. (See Appendix B, Tables B.9 - B.11 for equations)

\section{InVEST Water Yield}

One component of InVEST estimates an annual average water yield. In other words over a period of time ( $>10$ years), what is the average amount of water originating from a given watershed? Based on an equation developed by Zhang, Dawes, \& Walker (2001), InVEST uses a few basic soil, climate, and vegetation (land cover) variables that can reliably approximate annual average water yield over the long term. From Zhang et al. (2001), "the model is a practical tool that can be readily used to predict the long-term consequences of reforestation and has potential uses in catchment-scale studies of land use change." It uses basic relationships between the climate variables precipitation and PET with a soil's capacity to hold water available to plants. The PET is modified by a vegetation (land cover) type's evapotranspiration coefficient. It is a model parameter, along with root depth vegetation (land cover). The model does not account for groundwater interactions. 


\section{InVEST Water Purification}

The InVEST water purification model estimates the annual retention of phosphorus and nitrogen by the land cover types present in the study area. It also produces an annual export $(\mathrm{Kg})$ by stream-flow estimate useful for model calibration. InVEST uses two parameters to calculate the average flux for a map pixel of a given land cover type. These are the annual export coefficient for a land cover type, and nutrient retention rate expressed as a percentage. The model adjusts the export values based on the hydrologic sensitivity score which uses the water yield estimate. It is the relative dryness or wetness of a map pixel compared to the watershed's average water yield. It then tracks the loading of nitrogen or phosphorus as it moves downslope while accounting for each subsequent pixels loading and retention until it reaches a stream. At that point it is then aggregated to the outlet of the sub-watershed. A flow threshold, the number of pixels that must flow into each other before being considered a stream, was set to match as closely as to possible to the stream layer in the USGS National Hydrography Dataset (NHDplus, 2013). There is no uptake limit set for land cover types and in-stream processes that affect nutrients are unaccounted for in the model.

\section{InVEST Sediment Retention}

InVEST sediment retention, like the water purification module, estimates sediment retention by land cover and export by streamflow. The approach is to scale up the field-level developed Universal Soil Loss Equation (USLE) (Wischmeier \& Smith, 1978). The USLE incorporates the erosive potential of rainfall, the erodibility of soil, and 
slope with the adjustable parameters of $\mathrm{C}$ factor and $\mathrm{P}$ factor which account for vegetation (land cover) type and management practices. The USLE's solution is the amount (metric tons) of soil lost on average in a year. InVEST takes this field scale approach and equates a field or parcel with a map pixel, and like in water purification adds a retention rate. It is limited in the same way the water purification model with no uptake limit and accounting for in-stream processes. This model is sensitive to the size of the aggregation watershed and the flow threshold value used to estimate the number of upstream pixels required to initiate a stream pixel. To calibrate, flow threshold is set the same as InVEST nutrients, and the model was run using SWAT delineated watersheds used in scenario analysis. Results from each watershed nested in the gauged watersheds were summed and compared the empirical estimate.

\section{Mapping}

For the scenario analysis we summarize results of each model's output per subwatershed and normalized by area. It is important to understand if stream exports and retention of nutrient and sediments vary across the landscape in a similar way. We use Spearman's rho to assess the relationships among each InVEST model's outputs for each scenario. Finally, to address the question of potential changes in the distribution of ES across the study area in a summarized way, we present the scenario estimations for each model as an ES bundle. First the sub-watershed estimations are normalized at a range from 0.1 to 0.9 . A weighted average is then taken where water yield is given forty percent 
of the weight and TN retention, TP retention, and sediment retention each represent twenty percent, based on initial stakeholder inputs.

\section{E. Sensitivity Analysis}

In an effort to address uncertainty in model parameterization, each InVEST model underwent a sensitivity analysis. The Tualatin River West Linn gauge was the test basin because it has the most streamflow and water quality data. There is no recommended parameter range associated with the models, so the procedure used the calibrated values as a starting point. A single parameter type was adjusted at the same rate for each test run. A series of positive and negative adjustments were made for each parameter type, and the subsequent changes to the West Linn watershed estimate were reported. In some cases, a land cover's parameter reaches the maximum or minimum allowable value, and thus does not fully cover the set rate of change. For proportional parameters, we used 0.001 as the minimum, and 1.0 as the maximum. Effective retention in both water purification and sediment retention are a percentage thus the range was 0 to $100 \%$. For root depth we set the minimum to $10 \mathrm{~cm}$ and maximum to $7000 \mathrm{~cm}$, the same as the maximum in the soil depth dataset. Since the water purification model has the exact same structure for both phosphorus and nitrogen, we chose to test the sensitivity of just one, phosphorus. A minimum annual export coefficient was set at $1 \mathrm{~kg}$ per hectare and no maximum was set. 


\section{Results}

A. Calibration

Estimation models for stream export loadings produced in LOADEST display relatively good fit for most diagnostics with some exceptions for total suspended sediments (Table 3.3). The results suggest the amount of runoff and time both influence the amount of nutrients moving through the study area. To deal this these conflicting issues, we chose to parameterize the Tualatin sub-watersheds from 2001 to 2010 and then adjust to the full study period as a way to compromise between an apparent negative time trend and accounting for a larger period that displays larger fluctuations in runoff. Also the empirical estimates suggest that estimates of nutrient sources throughout the Tualatin are not distributed evenly. We reclassified a portion of the land cover map pixels prior to use in the water purification and sediment retention models. This allows for different parameters values to be used for those areas where higher stream load contributions were observed. (See Appendix B for additional information including parameter values Tables B.6 \& B.7.) 
Table 3.3

Load estimator program LOADEST results for three water quality parameters (Total Nitrogen - TN, Total Phosphorus - TP, Total Suspended Sediments - TSS) for sites in the Tualatin Basin (3) and Yamhill Basin (1), Oregon, U.S.A.. Models are adjusted maximum likelihood regressions with the explanatory variables flow and decimal time. Censored samples are under the detection limit.

Diagnostics include $\mathrm{R}^{2}$ and the Nash-Sutcliffe Index (NSE), percent bias (Bp), and Partial Load Ratio (PLR).

\begin{tabular}{|c|c|c|c|c|c|c|c|c|}
\hline \multicolumn{9}{|c|}{ Station - Tualatin River at West Linn - USGS ID 14207500} \\
\hline $\begin{array}{l}\text { Param. } \\
\text { (model) }\end{array}$ & $\begin{array}{l}\text { Calibration } \\
\text { Period }\end{array}$ & $\begin{array}{l}\mathrm{N} \\
\text { (cens.) }\end{array}$ & $\begin{array}{l}\text { Estimation } \\
\text { Period }\end{array}$ & $\mathrm{R}^{2}$ & NSE & $\mathrm{Bp}[\%]$ & PLR & $\begin{array}{l}\text { Mean } \\
\text { (kg/day) }\end{array}$ \\
\hline $\mathrm{TN}_{a}$ & $1974-2002$ & 545 & $\begin{array}{l}01 / 01 / 1981- \\
12 / 31 / 2010\end{array}$ & 0.95 & 0.93 & 0.115 & 1.001 & 8517 \\
\hline $\mathrm{TP}_{a}$ & $1974-2010$ & 972 & $\begin{array}{l}01 / 01 / 1981- \\
12 / 31 / 2010\end{array}$ & 0.92 & 0.65 & 5.629 & 1.056 & 787.5 \\
\hline $\mathrm{TSS}_{a}$ & $1988-2010$ & 828 & $\begin{array}{l}01 / 01 / 1981- \\
12 / 31 / 2010\end{array}$ & 0.94 & 0.06 & 11.135 & 1.111 & 101320 \\
\hline \multicolumn{9}{|c|}{ Station - Tualatin River at Dilley - USGS ID 14203500} \\
\hline $\mathrm{TN}_{a}$ & $1984-2011$ & 1007 & $\begin{array}{l}01 / 01 / 1981- \\
12 / 31 / 2010\end{array}$ & 0.88 & 0.68 & 3.148 & 1.031 & 771.65 \\
\hline $\mathrm{TP}_{a}$ & $1984-2011$ & $\begin{array}{l}1007 \\
(25)\end{array}$ & $\begin{array}{l}01 / 01 / 1981- \\
12 / 31 / 2010\end{array}$ & 0.84 & 0.67 & -2.804 & 0.972 & 69.95 \\
\hline $\mathrm{TSS}_{b}$ & $1984-2011$ & 1014 & $\begin{array}{l}01 / 01 / 1981- \\
12 / 31 / 2010\end{array}$ & 0.89 & 0.45 & -10.24 & 0.898 & 18303 \\
\hline \multicolumn{9}{|c|}{ Station - Fanno Creek at Durham - USGS ID 14206950} \\
\hline $\mathrm{TN}_{b}$ & $1993-2012$ & $622(1)$ & $\begin{array}{l}01 / 01 / 2001- \\
12 / 31 / 2010\end{array}$ & 0.98 & 0.93 & 2.7220 & 1.027 & 159.43 \\
\hline $\mathrm{TP}_{a}$ & $1993-2012$ & 733 & $\begin{array}{l}01 / 01 / 2001- \\
12 / 31 / 2010\end{array}$ & 0.98 & 0.66 & 1.753 & 1.018 & 21.31 \\
\hline $\mathrm{TSS}_{a}$ & $1993-2012$ & 530 & $\begin{array}{l}01 / 01 / 2001- \\
12 / 31 / 2010\end{array}$ & 0.93 & -1.76 & 46.091 & 1.461 & 7961 \\
\hline \multicolumn{9}{|c|}{ Station - Yamhill DEQ Water Quality Station } \\
\hline $\mathrm{TN}_{a}$ & $1994-2007$ & 132 & $\begin{array}{l}01 / 01 / 1996- \\
12 / 31 / 2010\end{array}$ & 0.97 & 0.77 & 8.855 & 1.089 & 9212 \\
\hline $\mathrm{TP}_{a}$ & $1994-2012$ & 164 & $\begin{array}{l}01 / 01 / 1996- \\
12 / 31 / 2010\end{array}$ & 0.97 & 0.85 & -1.738 & 0.983 & 896 \\
\hline $\mathrm{TSS}_{c}$ & $1994-2012$ & 164 & $\begin{array}{l}01 / 01 / 1996- \\
12 / 31 / 2010 \\
\end{array}$ & 0.96 & 0.72 & 3.579 & 1.036 & 334673 \\
\hline \multicolumn{9}{|c|}{ Model Forms } \\
\hline \multicolumn{9}{|c|}{$\ln ($ Load $)=a_{0}+a_{1} \ln Q+a_{2} \ln Q^{2}+a_{3} \sin (2 \pi$ dtime $)+a_{4} \cos (2 \pi$ dtime $)+a_{5}$ dtime $+a_{6}$ dtime ${ }^{2}$} \\
\hline \multicolumn{9}{|c|}{$\ln ($ Load $)=a_{0}+a_{1} \ln Q+a_{2} \ln Q^{2}+a_{3} \sin (2 \pi$ dtime $)+a_{4} \cos (2 \pi$ dtime $)+a_{5}$ dtime } \\
\hline \multicolumn{9}{|c|}{$\ln ($ Load $)=a_{0}+a_{1} \ln Q+a_{2} \ln Q 2$} \\
\hline
\end{tabular}




\section{InVEST Water Yield}

Water yield results indicate good agreement with empirical estimates (Figure 3.5). At the West Linn gauge which encompasses nearly the entire Tualatin basin has a consistent small bias averaging $6.4 \%$ for all time periods (Table 3.4). Multiple small withdrawals take place on the river, and one large diversion occurs in the lower river as streamflow is diverted to Lake Oswego in the adjacent watershed leaving a possible explanation for the bias (Rounds, Woods, \& Lynch, 1999). All estimates were within at least $11 \%$ of the empirical observation. As long as a sufficient number of years of data are used within the model, its simple conceptual approach reasonably predicts an average annual water yield.

InVEST water purification does not fully account for how changes in water yield affect stream loads of total phosphorus and total nitrogen. Structurally, it uses water yield to develop a hydrologic sensitivity score that adjusts the land use export coefficient. This score is a ratio that at least in our study area did not lead to any sizeable response from the load estimate (Table 3.5). The conclusion is that InVEST water purification relies heavily on determining stream loadings from the land cover input. 


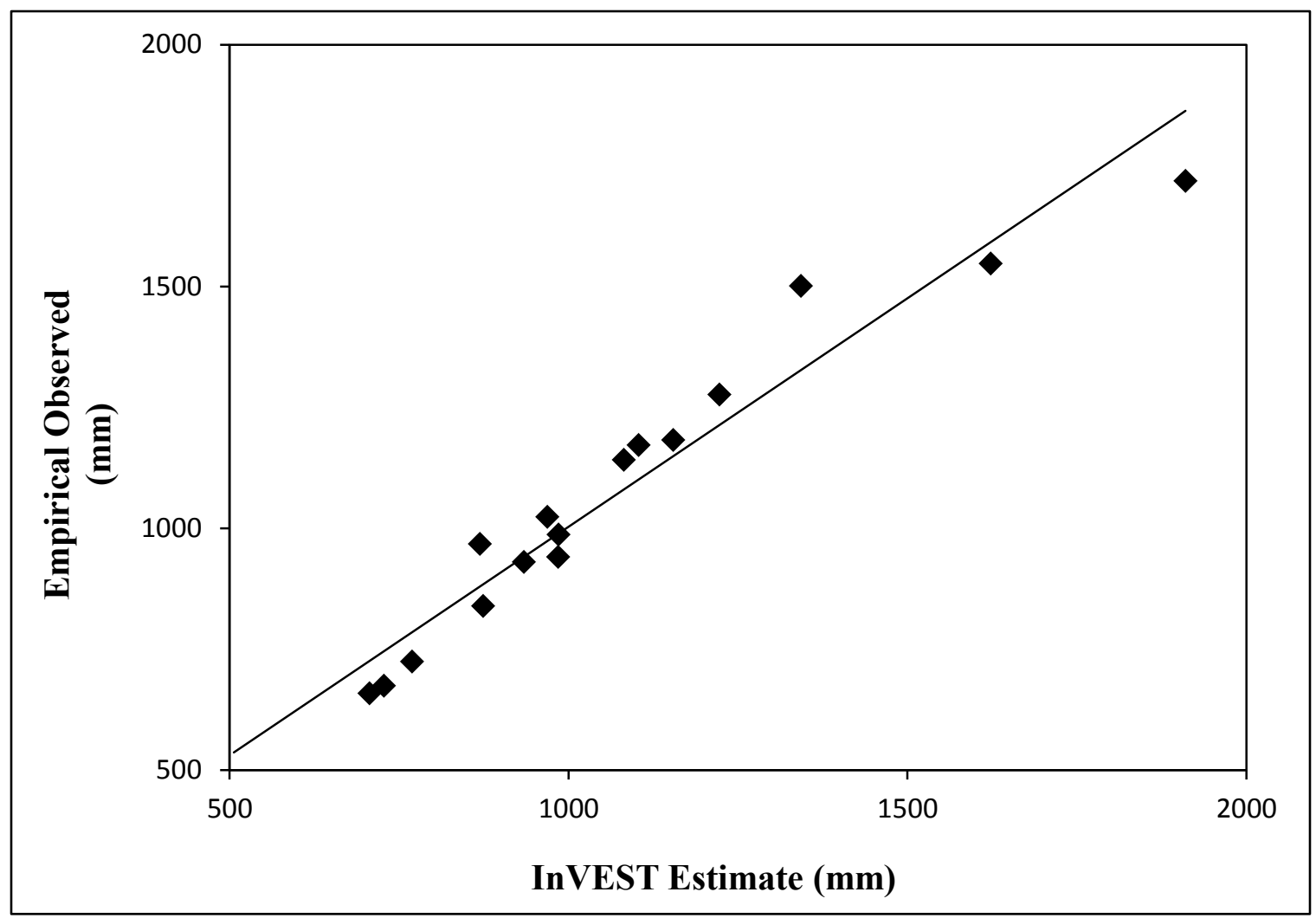

Figure 3.5

Scatterplot of all InVEST estimates against empirical observations for each sub-basin's average annual water yield $(\mathrm{mm})$. Basins with sufficient daily average flow data at the decadal scale for the thirty year study period $1981-2010$ were used. Two basins had each decade combined into a thirty year average and were also included in the calibration $(n=17)$. 
Table 3.4

Results of InVEST water yield calibration at eight flow gauges in the Tualatin and Yamhill basin study area.

\begin{tabular}{|c|c|c|c|c|}
\hline Location & Time Period & $\begin{array}{l}\text { Empirical Ave. } \\
\text { Ann. Yield (mm) }\end{array}$ & $\begin{array}{l}\text { InVEST modeled } \\
\text { Ave. Ann. Yield } \\
(\mathrm{mm})\end{array}$ & $\begin{array}{l}\text { Percent } \\
\text { Difference }\end{array}$ \\
\hline \multirow{4}{*}{$\begin{array}{l}14207500 \text { Tualatin River at } \\
\text { West Linn, OR }\end{array}$} & $1981-1990$ & 674 & 728 & $7.9 \%$ \\
\hline & $1991-2000$ & 839 & 874 & $4.2 \%$ \\
\hline & $2001-2010$ & 659 & 707 & $7.3 \%$ \\
\hline & $1981-2010$ & 724 & 770 & $6.3 \%$ \\
\hline \multirow{4}{*}{$\begin{array}{l}14203500 \text { Tualatin River at } \\
\text { Dilley, OR }\end{array}$} & $1981-1990$ & 930 & 934 & $0.4 \%$ \\
\hline & $1991-2000$ & 1172 & 1103 & $-5.8 \%$ \\
\hline & $2001-2010$ & 967 & 869 & $-10.1 \%$ \\
\hline & $1981-2010$ & 1023 & 969 & $-5.3 \%$ \\
\hline $\begin{array}{l}14206950 \text { Fanno Creek at } \\
\text { Durham, OR }\end{array}$ & $2001-2010$ & 492 & 506 & $2.8 \%$ \\
\hline \multirow{2}{*}{$\begin{array}{l}14202980 \text { Scoggins Creek } \\
\text { below Hagg Lake near Gaston, } \\
\text { OR }\end{array}$} & $1981-1990$ & 941 & 985 & $4.7 \%$ \\
\hline & $1991-2000$ & 1183 & 1155 & $-2.3 \%$ \\
\hline \multirow{2}{*}{$\begin{array}{l}14194150 \text { South Yamhill River } \\
\text { at McMinnville, OR }\end{array}$} & $1996-2010$ & 1141 & 1082 & $-5.17 \%$ \\
\hline & $2001-2010$ & 987 & 985 & $-0.1 \%$ \\
\hline $\begin{array}{l}14192500 \text { South Yamhill River } \\
\text { near Willimina, OR }\end{array}$ & $1981-1990$ & 1501 & 1343 & $-10.5 \%$ \\
\hline $\begin{array}{l}14193000 \text { Willimina Creek near } \\
\text { Willimina, OR }\end{array}$ & $1981-1990$ & 1276 & 1223 & $-4.2 \%$ \\
\hline 14196001 Haskins Creek below & $1981-1990$ & 1547 & 1623 & $-4.9 \%$ \\
\hline McMinnville, OR & $1991-2000$ & 1718 & 1910 & $11.2 \%$ \\
\hline
\end{tabular}




\section{InVEST Water Purification}

The empirical estimate for the single Yamhill sampling station showed higher stream loading estimates than in the Tualatin. It required a higher parameterization for this reason. We hypothesized that the larger amount of agricultural land in the Yamhill basin leads to more intensive use and can lead to increased export coefficients of the agricultural land cover. Also only sixteen years of data was used to develop the load estimate therefore the temporal dynamics of both basins are not being captured in the same way. Calibration results for both total nitrogen and total phosphorus show a close match to Yamhill as this basin was calibrated directly on 15 years of available data. Tualatin exhibits more error but this is likely due to the procedure of adjusting the 2001 2010 to the full thirty year study period plus the lack of point source data for the first decade (Table 3.6).

Table 3.5

Output of InVEST water purification for total phosphorus two locations on the Tualatin River at two different time periods of varying amounts of annual average water yield. Final calibration parameter values were used in all cases. The drier $2001-2010$ period is over predicted in both cases compared to the wetter 1990s whose stream loadings better match the annual average for the entire study period.

\begin{tabular}{lrrrrr}
\hline $\begin{array}{l}\text { Location: } \\
\text { Gauge and } \\
\text { station }\end{array}$ & Time Period & $\begin{array}{l}\text { InVEST Water Yield } \\
\text { Estimate (Empirical } \\
\text { Observation) }\end{array}$ & $\begin{array}{l}\text { Empirical } \\
\text { Estimate of Ave. } \\
\text { Ann. Stream } \\
\text { Load (Kg/yr.) }\end{array}$ & $\begin{array}{l}\text { InVEST Ave. } \\
\text { Ann. Stream } \\
\text { Load (Kg/yr.) }\end{array}$ & $\begin{array}{l}\text { Percent } \\
\text { Difference }\end{array}$ \\
\hline $\begin{array}{l}14207500 \\
\text { West Linn }\end{array}$ & $1991-2000$ & $874(838)$ & 173541 & 166958 & $-3.79 \%$ \\
$\begin{array}{l}14207500 \\
\text { West Linn }\end{array}$ & $2001-2010$ & $707(659)$ & 98719 & 166919 & $69.08 \%$ \\
14203500 & $1991-2000$ & $1103(1172)$ & 31804 & 33154 & $4.24 \%$ \\
$\begin{array}{l}\text { Dilley } \\
14203500\end{array}$ & $1991-2000$ & $869(967)$ & 20517 & 33240 & $62.01 \%$ \\
Dilley & & & & & \\
\hline
\end{tabular}


Table 3.6

Results of calibration for sub-watersheds inside the study area modeled with InVEST's water purification model for total nitrogen (TN) and total phosphorus (TP). The West Linn and Dilley estimates are based on thirty years of data from 1981 to 2010. The Yamhill station estimate is based on 15 years of data.

\begin{tabular}{|c|c|c|c|c|c|c|}
\hline Location & Nutrient & $\begin{array}{l}\text { Empirical } \\
\text { Ave. Ann. } \\
\text { Stream Load } \\
(\mathrm{Kg} / \mathrm{yr} .)\end{array}$ & $\begin{array}{l}\text { Loading } \\
\text { Estimate for } \\
\text { Point Sources } \\
\text { (Kg/yr.) }\end{array}$ & $\begin{array}{l}\text { Adjusted Ave. } \\
\text { Ann. Loading } \\
\text { (Kg/yr.) }\end{array}$ & $\begin{array}{l}\text { InVEST } \\
\text { Ave. Ann. } \\
\text { Loading } \\
\text { (Kg/yr.) }\end{array}$ & $\begin{array}{l}\text { Percent } \\
\text { Difference }\end{array}$ \\
\hline $\begin{array}{l}14207500 \\
\text { West Linn }\end{array}$ & TN & 2893390 & 1064640 & 1828745 & 1487776 & $-18.64 \%$ \\
\hline $\begin{array}{l}14203500 \\
\text { Dilley }\end{array}$ & $\mathrm{TN}$ & 352872 & 0 & 352872 & 382829 & $8.49 \%$ \\
\hline Yamhill DEQ & $\mathrm{TN}$ & 3305467 & 80775 & 3224691 & 3217423 & $-0.23 \%$ \\
\hline $\begin{array}{l}14207500 \\
\text { West Linn }\end{array}$ & TP & 252735 & 77891 & 174844 & 167012 & $-4.48 \%$ \\
\hline $\begin{array}{l}14203500 \\
\text { Dilley }\end{array}$ & $\mathrm{TP}$ & 29069 & 0 & 29069 & 33243 & $14.36 \%$ \\
\hline Yamhill DEQ & $\mathrm{TP}$ & 316017 & 2682 & 313336 & 308166 & $-1.65 \%$ \\
\hline
\end{tabular}

\section{InVEST Sediment Retention}

As with the water purification model, the Tualatin and Yamhill basins needed separate parameterization with Yamhill being similarly treated. Initially, it was anticipated that sediments would be underestimated using the InVEST model as it only accounts for sheet wash erosion. No mechanisms are available for gullying or stream bank erosion. This turned out not to be the case as the initial runs produced large overestimates. Parameters for most land cover classes were set low in order to reach results closely matching the empirical export estimates (Table 3.7). Fanno Creek's results were reasonable, but it must be noted that it is only based on ten years of data adjusted with a simple bias correction (subtracting the amount of over estimation calculated by LOADEST) for a regression model with poor diagnostics. 


\section{Table 3.7}

Results of calibration for sub-watersheds inside the study area modeled with InVEST's sediment retention model.

\begin{tabular}{lcrrr}
\hline Location & Time Period & $\begin{array}{l}\text { Empirically Estimated Average } \\
\text { Annual Export (T/yr.) }\end{array}$ & $\begin{array}{l}\text { InVEST Average } \\
\text { Annual Export (T/yr.) }\end{array}$ & \multicolumn{2}{l}{$\begin{array}{l}\text { Percent } \\
\text { Difference }\end{array}$} \\
\hline $\begin{array}{l}14207500 \\
\text { West Linn }\end{array}$ & $1981-2010$ & 31908 & 32081 & $0.54 \%$ \\
14203500 & $1981-2010$ & 7813 & 8075 & $3.35 \%$ \\
$\begin{array}{l}\text { Dilley } \\
\text { Yamhill DEQ }\end{array}$ & $1996-2010$ & 121284 & 123153 & $1.54 \%$ \\
14206950 & $2001-2010$ & 1488 & 1582 & $6.36 \%$ \\
Fanno Creek & & & & \\
\hline
\end{tabular}

\section{B. Scenarios}

Maps of InVEST estimates in absolute terms show small to no changes (Appendix B, Figures B.4 - B.10). A wide range of values are estimated per sub-watershed in the study area with higher values for exports and retention of nutrients and sediments in the Yamhill basin. This obscures patterns seen in the Tualatin under the value ranges mapped. We focus on the percent changes from historic to future scenarios here.

\section{Water Yield}

The InVEST water yield model suggests that long term change in the supply of water to the basins in the study area are much more reliant on the long term change in climatic conditions rather than land cover. The amount of precipitation is the most important variable deciding runoff in the InVEST model (Appendix B, Table B.9). There is a land cover effect but relative to the whole study area, only a fraction of the study area changes (between $2.5 \%$ to $7 \%$ depending on the scenario). It serves to modulate the PET estimate that is mainly driven by the climate variables minimum and maximum 
temperature and solar radiation. These are the variables used in the Hargreaves method for calculating PET. Sub-watershed patterns of water yield are similar among the three changes in urbanization (Figure 3.6). For two of the low and medium climate scenarios, InVEST projects a wetter climate over the next 40 years. Only in the high scenario is this reversed as the higher maximum temperatures lead to higher average annual actual evapotranspiration. Projected precipitation levels do not compensate for this (Figures 3.1 \& 3.3). The spatial pattern suggests sub-watersheds lower in the basins will see more change. The difference maps reveal subtle differences in yield change for some lowland sub-watersheds. These changes are related to either new urbanization or riparian buffer installation. With less vegetation present in a developed area, there is less evapotranspiration and more potential for runoff. However, this is complicated by the intensity of urban cover types having varying potential for evapotranspiration. When riparian buffers are added, there is an effect of reducing the increase or exacerbating the decrease in yield as the vegetation replaced had less evapotranspiration potential than the natural vegetation. The overall results suggest that land cover effects on long term water yield are small compared to climate effects. 


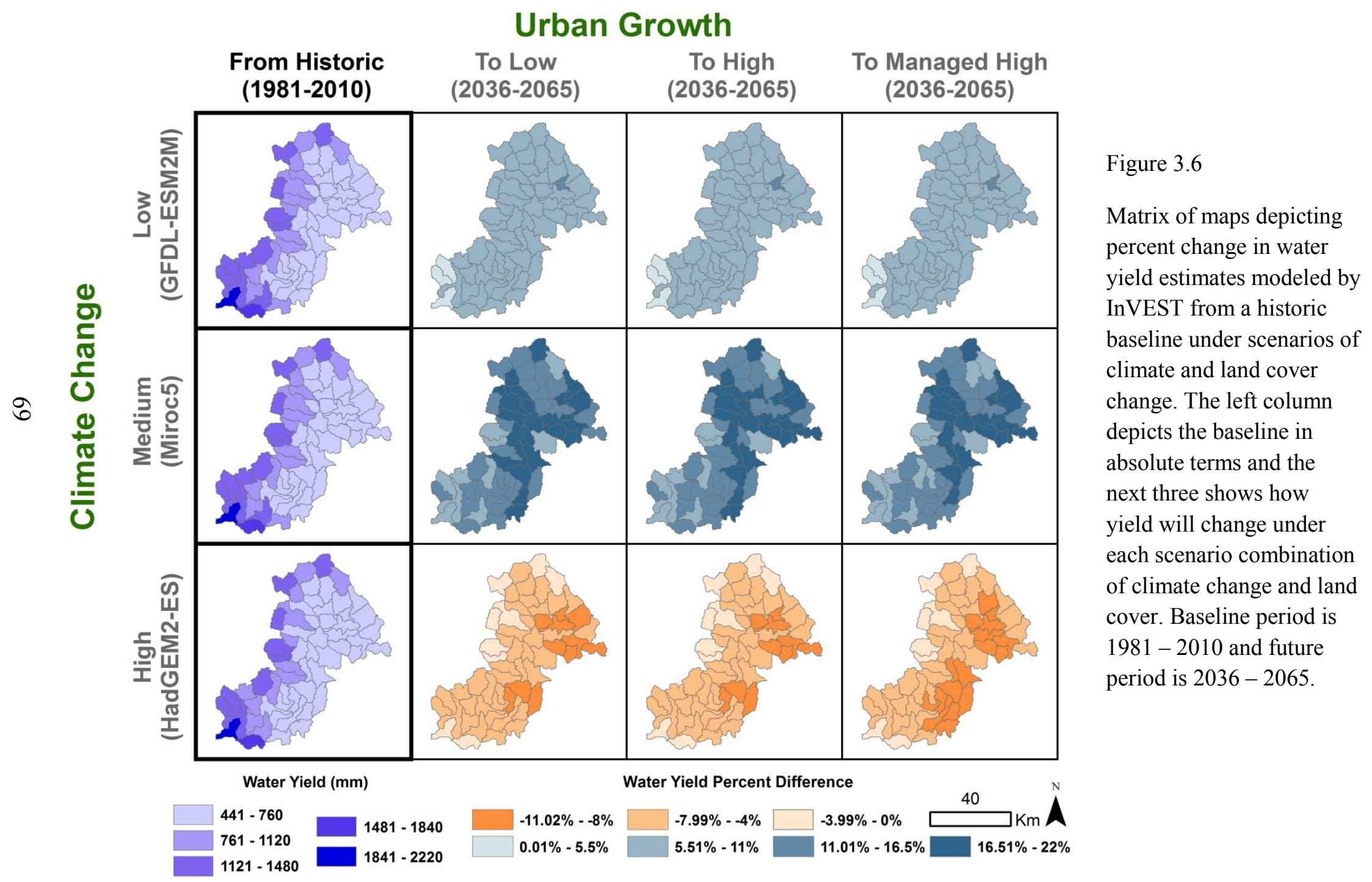




\section{Water Purification}

Spatial patterns of exports are similar for TN and TP (Appendix B). Higher exports occur only in the urbanized watersheds of the Tualatin basin and in some scenarios, the interstitial Chehalem Creek watershed as well. When looking at the progression of scenarios, it should be noted that what changes do occur are the same under each climate scenario. InVEST's mechanism for estimating nutrient export and retention is driven largely by land cover. Maps of the percent differences from baseline to future scenarios reveal distinct patterns of nutrient export change (Figures $3.7 \& 3.8$ ). There are clear differences in what occurs in the Yamhill and the Tualatin basins. Nutrient exports increase in the urbanizing regions of the Tualatin with the opposite being true in the Yamhill. The data used to set InVEST's parameters suggested that Yamhill exports much more total nitrogen and phosphorus than does the Tualatin. Most of this is attributed to agriculture thus a change to urban land cover types has an export reduction effect. Both figures show that widespread use of riparian buffers could potentially lead to decreases in stream exports or mitigate the effects of increased urbanization like near the mouth of the Tualatin. Sub-watersheds that were already urbanized see some increases in exports with additional urban land. 


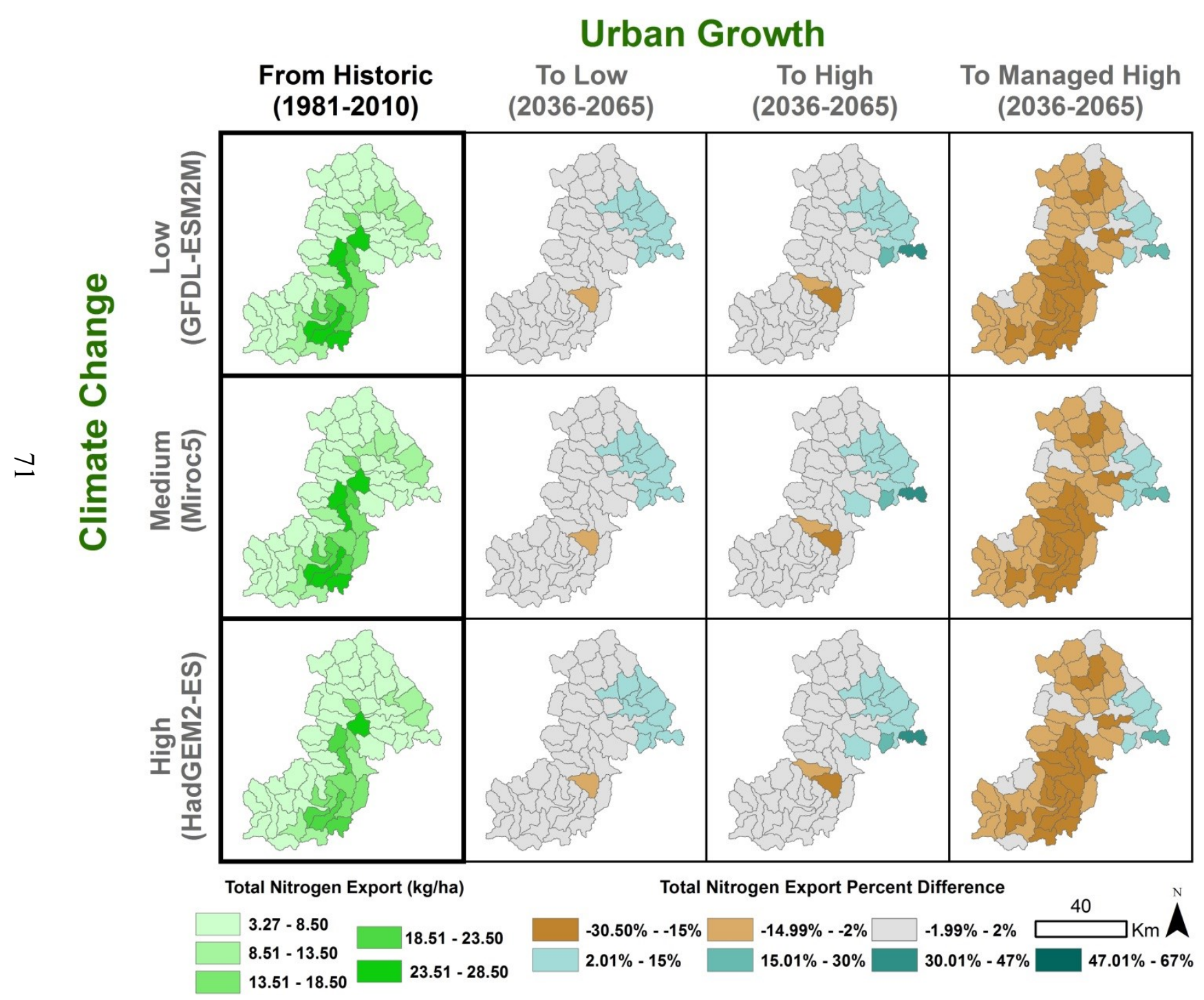

Figure 3.7

Matrix of maps depicting percent change in total nitrogen (TN) export estimates modeled by InVEST from a historic baseline under scenarios of climate and land cover change. The left column depicts the baseline in absolute terms and the next three shows how yield will change under each scenario combination of climate change and land cover. Baseline period is 1981 2010 and future period is $2036-2065$. 


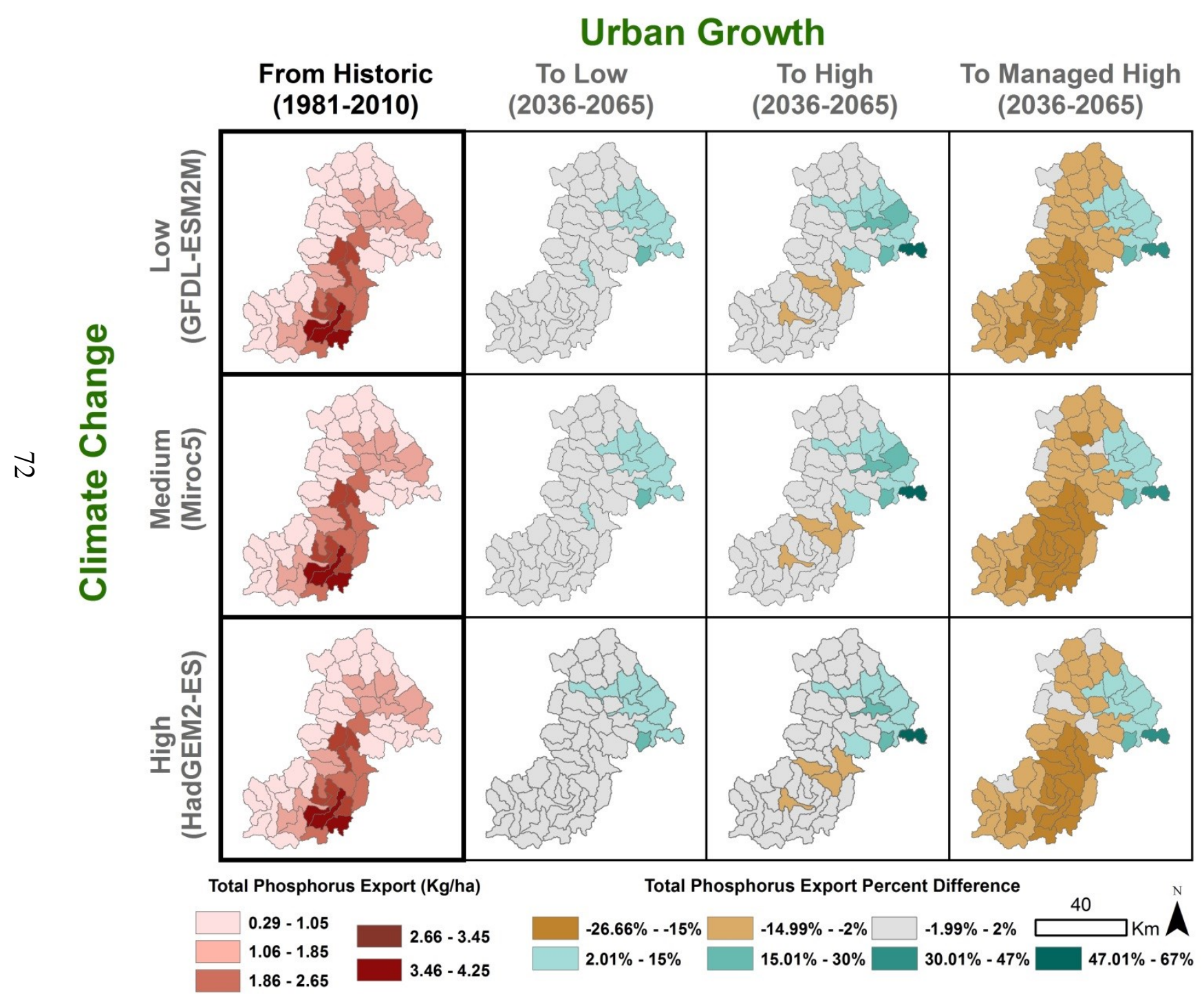

Figure 3.8

Matrix of maps depicting percent change in total phosphorus (TP) export estimates modeled by InVEST from a historic baseline under scenarios of climate and land cover change. The left column depicts the baseline in absolute terms and the next three shows how yield will change under each scenario combination of climate change and land cover. Baseline period is 1981 2010 and future period is 2036 - 2065. 
Maps of nutrient retention show a similar pattern to the maps of nutrient export. Correlations show this be the case for all scenarios, and especially for total phosphorus (Appendix B, Table B.8). Nutrient retention estimates are tied to the percent effective retention parameter in InVEST. For instance, in the Yamhill basin the sub-watershed where we expect the most urbanization sees a decrease in exports. We also observed decreases in retention estimates (Figures 3.9 \& 3.10). Exports from agricultural land cover are high but this also means that more is retained. There is no uptake limit where there is more upslope nutrient mobilization, so there is also more retention in the downslope pixels. Urban land cover exports fewer nutrients and thus there is also less to retain. In the Tualatin, total phosphorus exports from urban lands are parameterized to be larger than agriculture, and thus more retention is also observed as more lands become urbanized. Urban and agricultural lands have very similar export coefficients for nitrogen, but agriculture has a slightly higher retention rate (Appendix B, Table B.6). This explains the decrease in retention rate for total nitrogen in the sub-watersheds with increased urbanization. Widespread installation of riparian buffer strips has the potential to increase retention of nutrients in the agriculture dominated sub-watersheds. This is based on the assumption that it can retain a high percentage of nutrients that were exported upslope of them. Their placement near streams results in highest effectiveness since all mobilized nutrients must pass through a riparian pixel prior to export to a stream. 


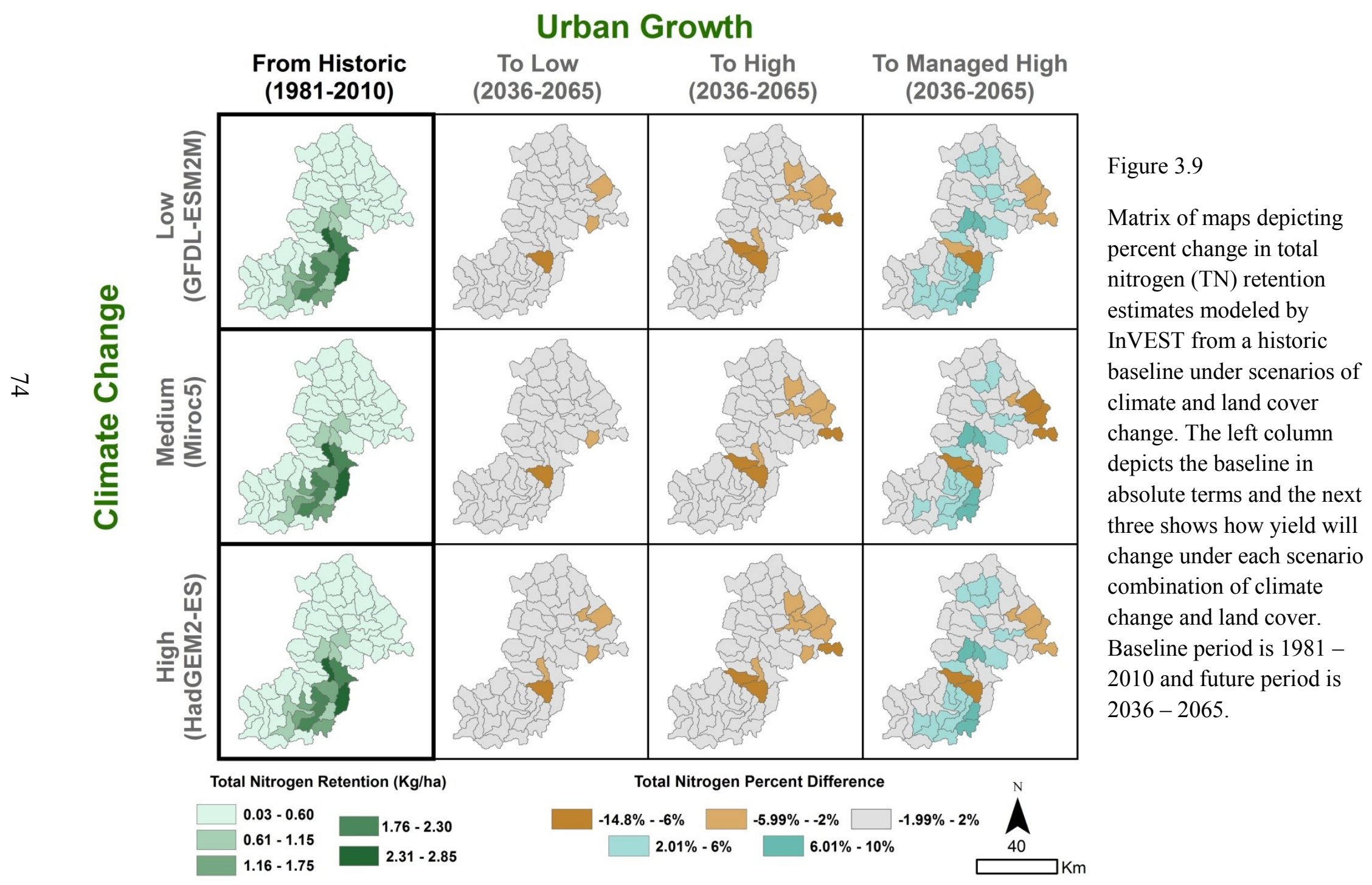




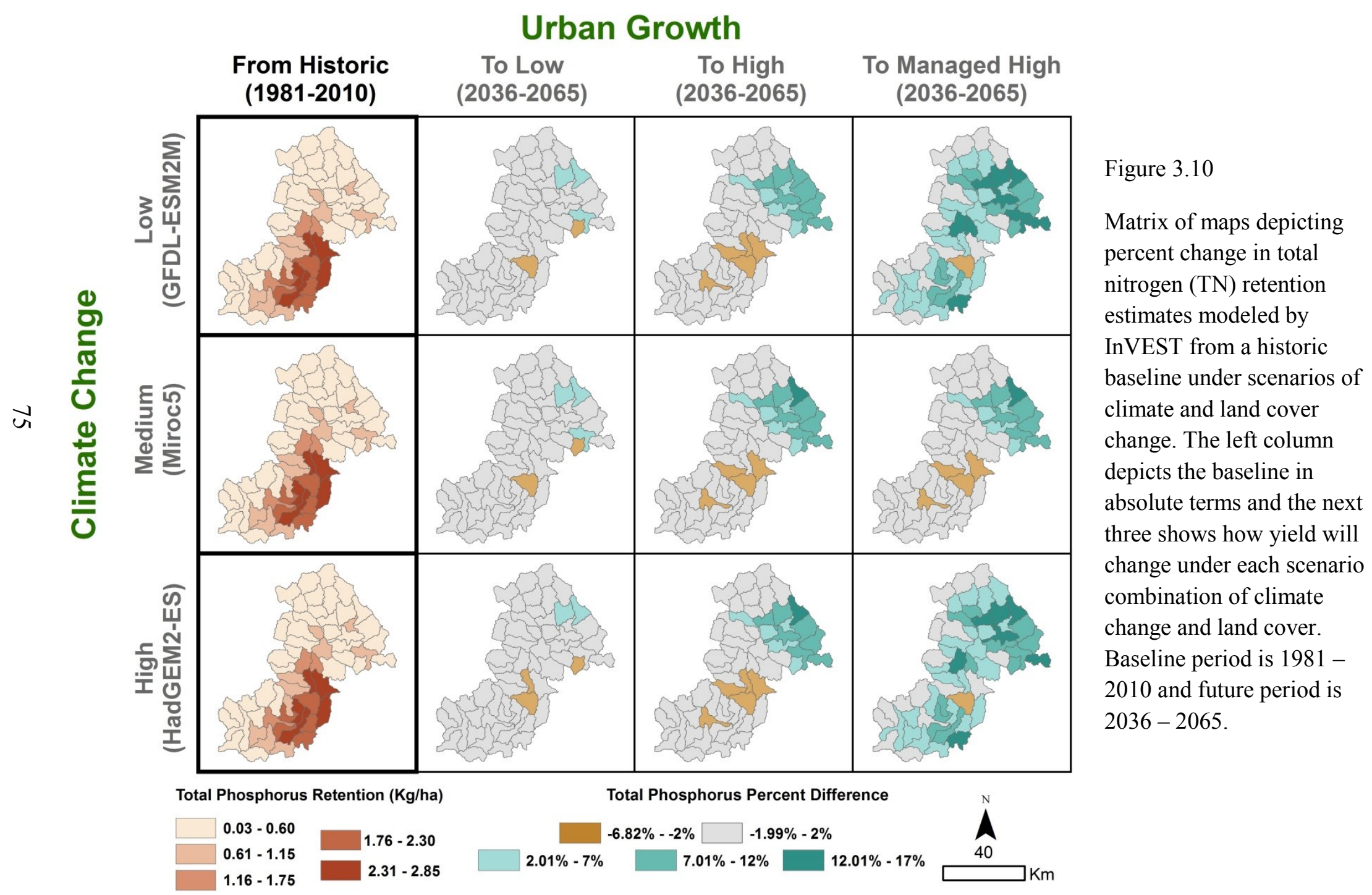




\section{Sediment Retention}

Sediment retention results suggest that there are influences from both land cover and climate, but climate is the main driver (Figure 3.11). Large increases in soil mobilization are projected in the medium climate scenarios. Like the water yield results, these are the wettest scenarios. This translates to higher erosive potential. Estimates are at the average annual scale, but by using the Fournier coefficient in the erosivity estimate, monthly variation is incorporated. The high difference in winter rainfall between the historic baseline and the future in the Miroc5 climate model is the likely driver (Figure 3.2). The same can be said of the other scenarios but to a lesser extent. Again, as with the nutrient modeling, riparian buffer strips can potentially reduce exports to less than historic rates. For the medium climate scenario soil loss potential through mobilization is great enough that the buffers can only mitigate the effects of a more wet winter.

Sediment retention maps show a different pattern than exports, and this is supported by a weak negative correlative relationship between the two (Appendix B, Figures B.9 \& B.10, Table B.8). High slope uplands have large potential for soil mobilization, but the natural forest vegetation cover has high retention capacity. Lowlands have less soil mobilization potential, but the land cover types present, agriculture and urban, are parameterized to allow more sediment mobilization and less retention. This explains the negative relationship present in the correlation analysis. Because of the landscape wide projected climate induced export increases, it has the effect of across the board increases in retention (Figure 3.12). As with the nutrient model, there is no sediment trapping limit, thus as exports increase, so does overall retention. 


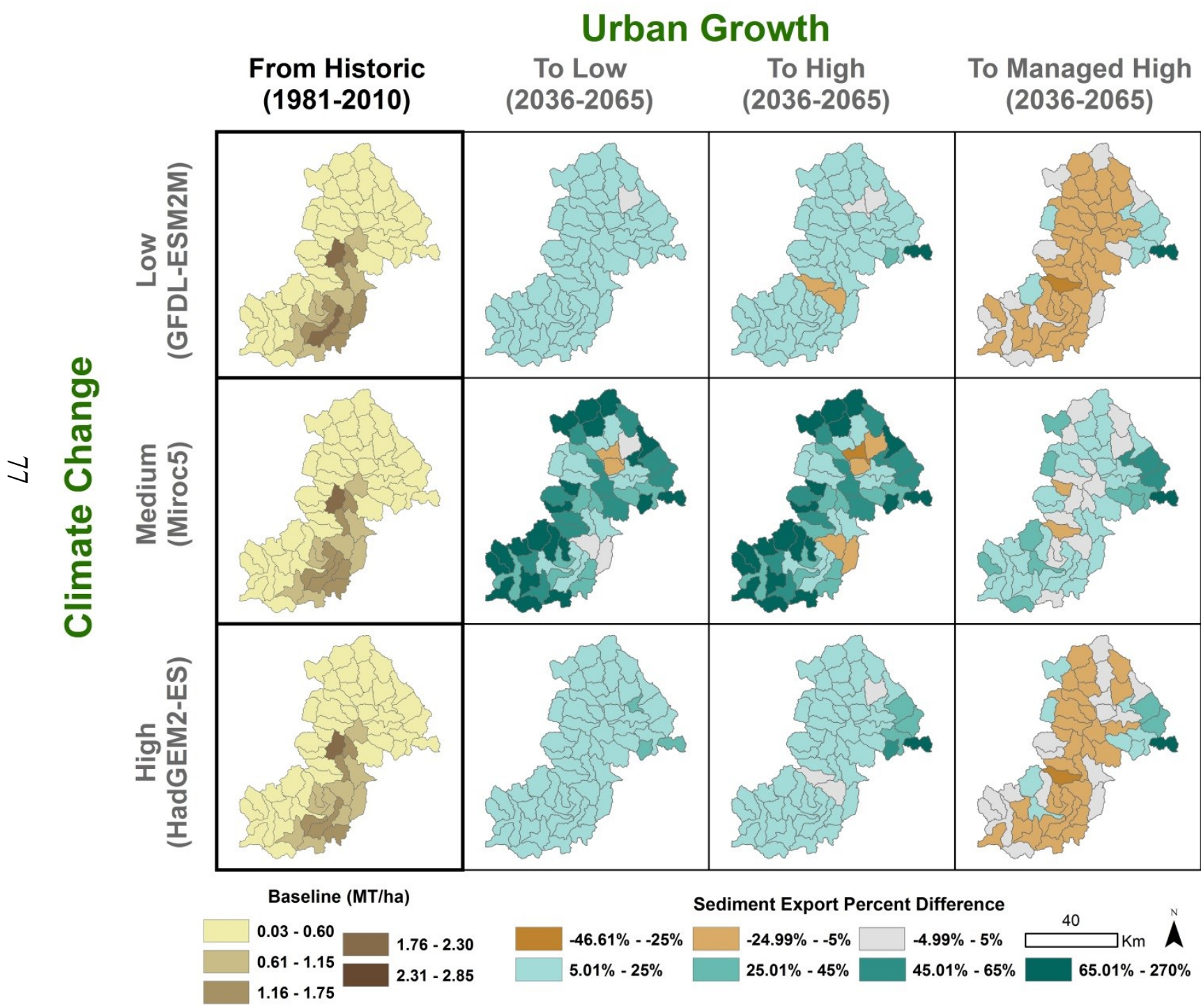

Figure 3.11

Matrix of maps depicting percent change in sediment export estimates modeled by InVEST from a historic baseline under scenarios of climate and land cover change. The left column depicts the baseline in absolute terms and the next three shows how yield will change under each scenario combination of climate change and land cover. Baseline period is 1981 2010 and future period is 2036 - 2065. 


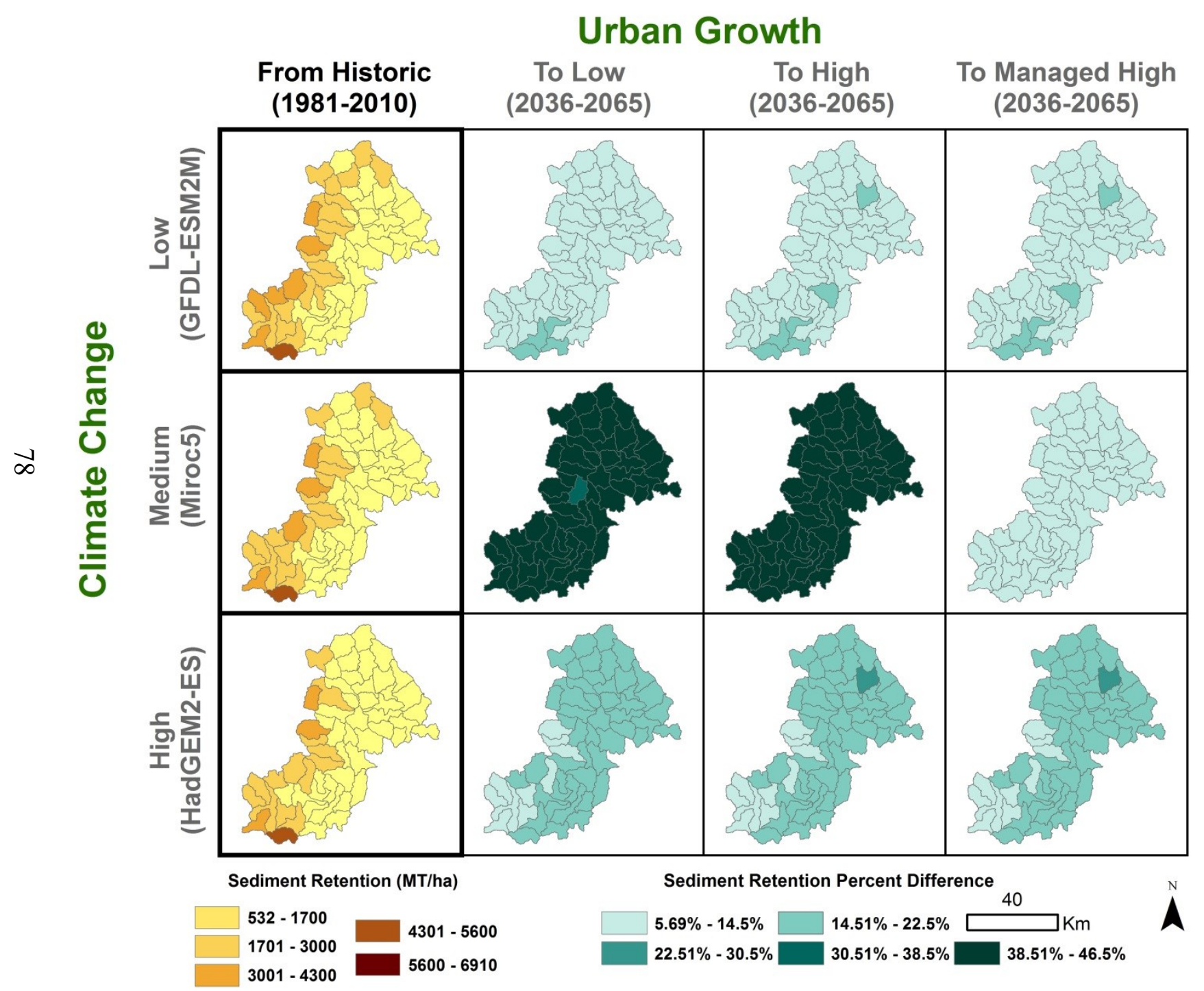

Figure 3.12

Matrix of maps depicting percent change in sediment retention estimates modeled by InVEST from a historic baseline under scenarios of climate and land cover change. The left column depicts the baseline in absolute terms and the next three shows how yield will change under each scenario combination of climate change and land cover. Baseline period is 1981 2010 and future period is $2036-2065$. 
The maps of the freshwater estimates in absolute terms display little difference among scenarios (Appendix B, Figures B.4 - B.10). When the results are normalized and bundled, there are small changes in the ranking of each sub-watershed (Figure 3.13). The Yamhill basin contains the majority of sub-watersheds, providing the highest levels of bundled services under the weighting scheme used. Slight shifts do occur where a few of the watersheds in Yamhill increase in bundled ES with installation of riparian buffers. The higher values in the upland portion of the study area have a higher bundled value particularly the two sub-watersheds in the southwest of the Yamhill basin due to high water yield estimates which are also weighted at double the other freshwater ES. 


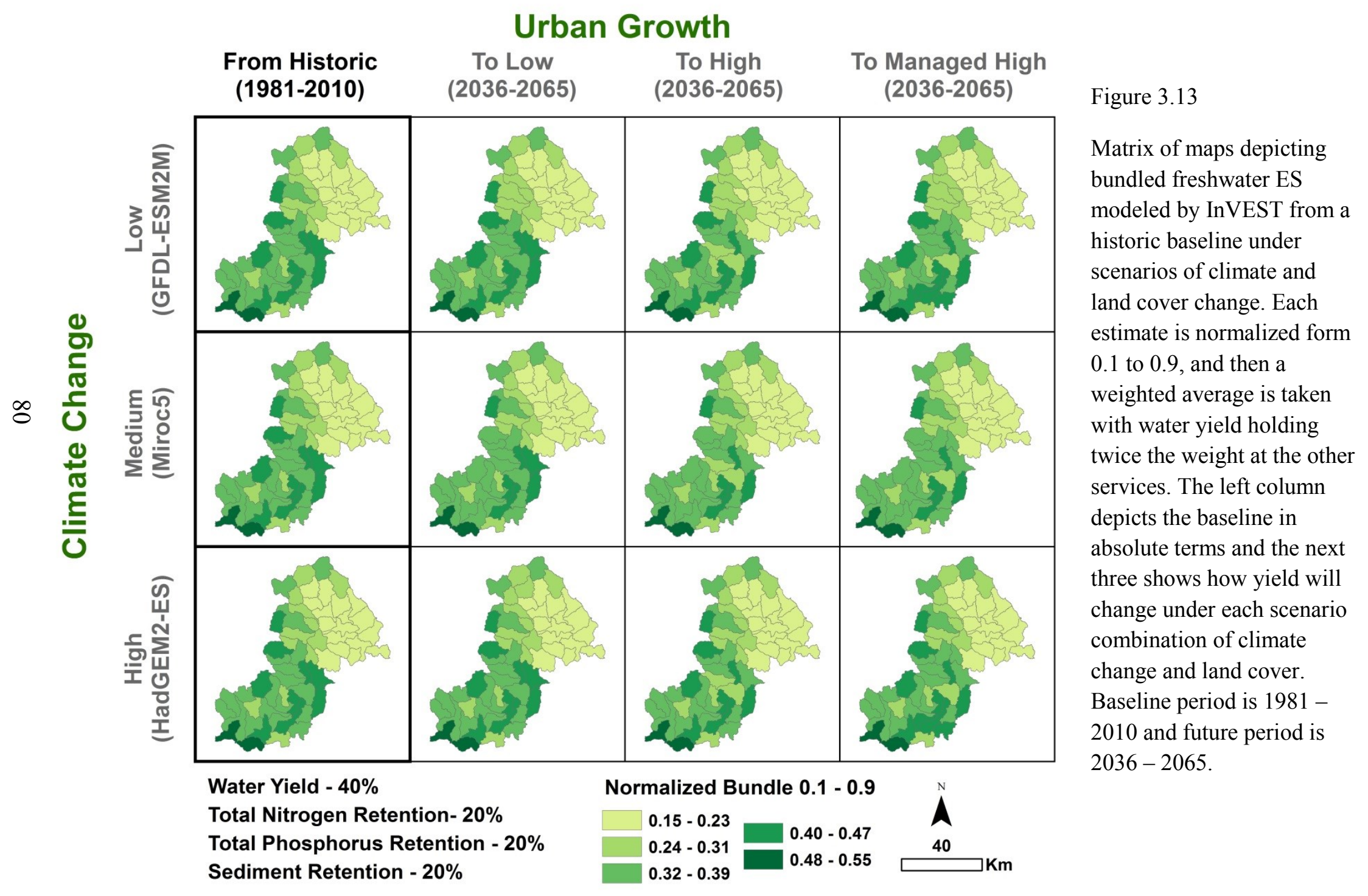




\section{InVEST Sensitivity}

All available parameters in InVEST display some degree of sensitivity. For water yield, most parameters are set to relatively high values. This is supported by the sensitivity evidence showing further reduction in all three parameters, the evapotranspiration coefficient, root depth, and the Zhang seasonality coefficient all increase yield (Table 3.8). In a system where peak rainfall and peak potential evapotranspiration are largely out of phase like in our study area, it suggests water storage in soil and vegetation with relatively high transpiration rates help explain long term annual average water yield.

Table 3.8

Sensitivity analysis of parameters in the InVEST water yield model. Calibrated model for the Tualatin River at the West Linn gauge (14207500) was used as test basin. Parameters were adjusted to amount shown until the minimum or maximum was reached. (see Appendix for description of parameters and model equations)

\begin{tabular}{lll}
\hline Parameter & Adjustment & Response (mm) \\
\hline Evapotranspiration coefficient (etk) & Down 0.2 & 95.8 \\
Min. 0.001 - Max. 1.0 & Down 0.1 & 47.4 \\
& Down 0.05 & 23.6 \\
& Up 0.1 & -45 \\
& Up 0.05 & -22.7 \\
Root Depth in mm & Down 2000 & 32 \\
Min. 10 - Max. 7000 & Down 1000 & 15.8 \\
& Down 500 & 0 \\
& Up 2000 & -0.8 \\
& Up 1000 & -0.8 \\
Zhang coefficient & Up 500 & -0.8 \\
(set at 10 in calibration) & 9 & 3.2 \\
Min. 1 - Max. 10 & 5 & 22.5 \\
\hline
\end{tabular}

The water purification model sensitivity tests appear to confirm the observations seen in the scenario maps. Clearly as exports coefficients are reduced so does estimated exports of stream loading, but retention estimates are also reduced and with an increase 
the pattern is reversed (Table 3.9). Also the export coefficient needs to be increased a substantial amount in order to see a much smaller response in exports estimates. The effective retention percentage has a symmetrical effect on exports and retention rates. Depending on how the rate is adjusted, one will go up at the same rate the other goes down (Figure 3.14). There is a greater magnitude of effect for this parameter's reduction. This suggests that there is a decline in its sensitivity as retention rate is increased. Manipulating the flow threshold effectively works the same way as the effective retention parameter. It is inadvisable to use this as a true parameter as it should mimic the actual stream layer in the study area as closely as possible.

Table 3.9

Sensitivity analysis of parameters in the InVEST water purification model. Calibrated model for the Tualatin River at the West Linn gauge (14207500) was used as test basin. Parameters were adjusted to amount shown until the minimum or maximum was reached. (See Appendix B for description of parameters and model equations.)

\begin{tabular}{lrrr}
\hline Parameter & Adjustment & $\begin{array}{l}\text { Export } \\
\text { Response } \\
(\mathrm{Kg} / \mathrm{ha})\end{array}$ & $\begin{array}{l}\text { Retention } \\
\text { Response } \\
(\mathrm{Kg} / \mathrm{ha})\end{array}$ \\
\hline Land Cover Export coefficient (Kg/ha) & Down 5000 & -0.77 & -1.65 \\
Min. 0 - Max. None & Down 2000 & -0.52 & -1.26 \\
& Down 1000 & -0.28 & -0.71 \\
& Up 5000 & 1.43 & 3.56 \\
& Up 2000 & 0.57 & 1.43 \\
& Up 1000 & 0.29 & -1.45 \\
Effective Retention (\%) & Down 25 & 1.45 & -0.67 \\
Min. 0 - Max. 100 & Down 10 & 0.67 & -0.50 \\
& Down 5 & 0.50 & 0.54 \\
& Up 25 & -0.53 & 0.35 \\
& Up 10 & -0.35 & 0.23 \\
Flow Threshold (calibrated model set at 1300) & Up 5 & -0.23 & -0.28 \\
Min. 1 - Max. None & Down 800 & 0.28 & 0.13 \\
\hline
\end{tabular}




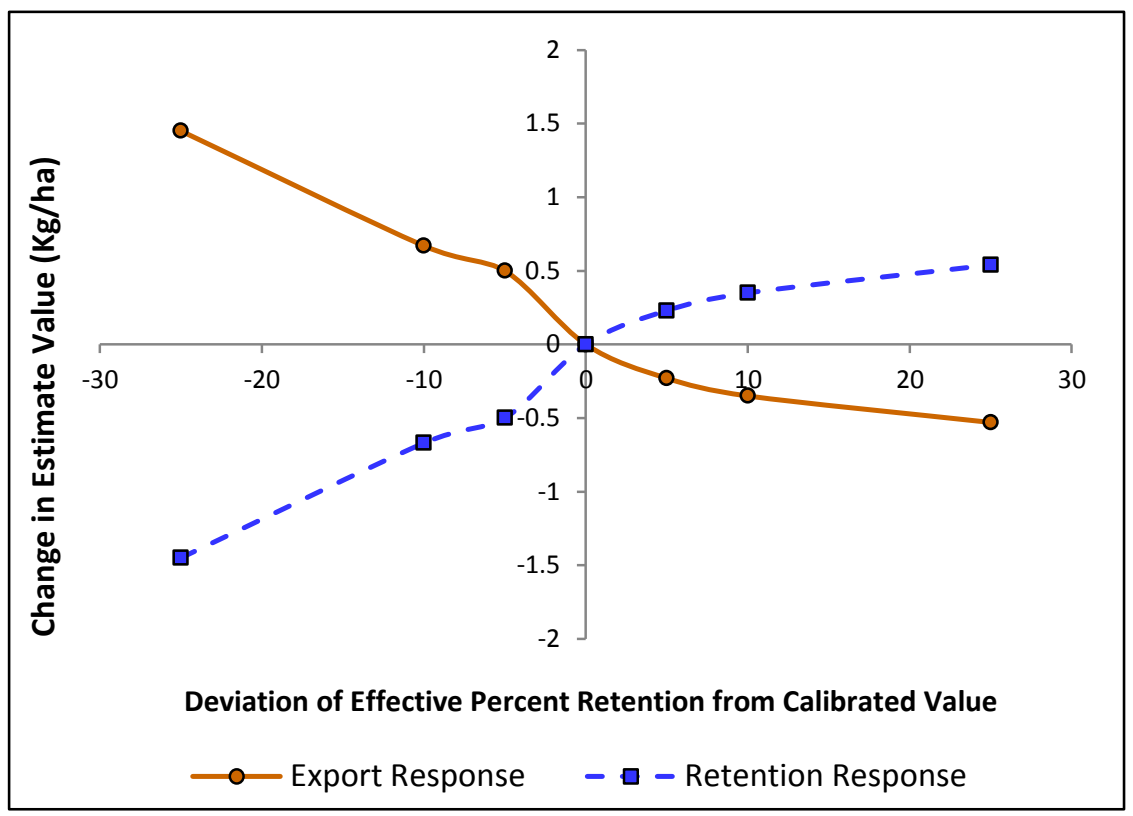

Figure 3.14

Graph showing the symmetrical response of the export and retention estimate to the percent retention parameter in the InVEST water purification model. The x-axis is the change in percent for the calibrated value. The $y$-axis shows the response in the per hectare estimate. The test basin used the West Linn gauge which is nearly the entire Tualatin basin.

The sediment retention model has much more sensitivity to the retention estimate than to the export (Table 3.10). Crop (C) and management (P) factor show a great degree of sensitivity especially when they are adjusted together. Unexpectedly, C-factor, when adjusted by itself, will increase retention until a threshold is reached somewhere just below a value of 0.05 displaying non-linear sensitivity effects (Figure 3.15). Both $\mathrm{C}$ and $\mathrm{P}$ are multipliers in the USLE with the same value range. High starting $\mathrm{C}$-factor in the row crop category is the only reason for its differing behavior (Appendix B, Table B.6). The effective retention parameter exhibits similar behavior to the water purification model, but its insensitivity to increasing percentages appears to be magnified. The analysis suggest although this parameter is meant to characterize the ecosystem service 
capacity of a land cover type, it is in fact one of the least important parameters with respects to the sediment model. The length slope factor determines when one of two equations in the model is used for determining slope factor in USLE (Appendix B, Table B.11). It appears to be a major determinant in retention estimates. InVEST documentation suggests its value should be where traditional agricultural practices stop to switch to slope stabilization techniques (Tallis et al., 2013). They suggest this value should be determined with at least some field observations. We have not done this but it is likely that this threshold is lower than the default of $75 \%$. We are producing overestimations, slightly for exports and potentially grossly for retention. Retention also appears much more sensitive to the flow threshold, although again it is suggested that this should mimic natural conditions as closely as possible.

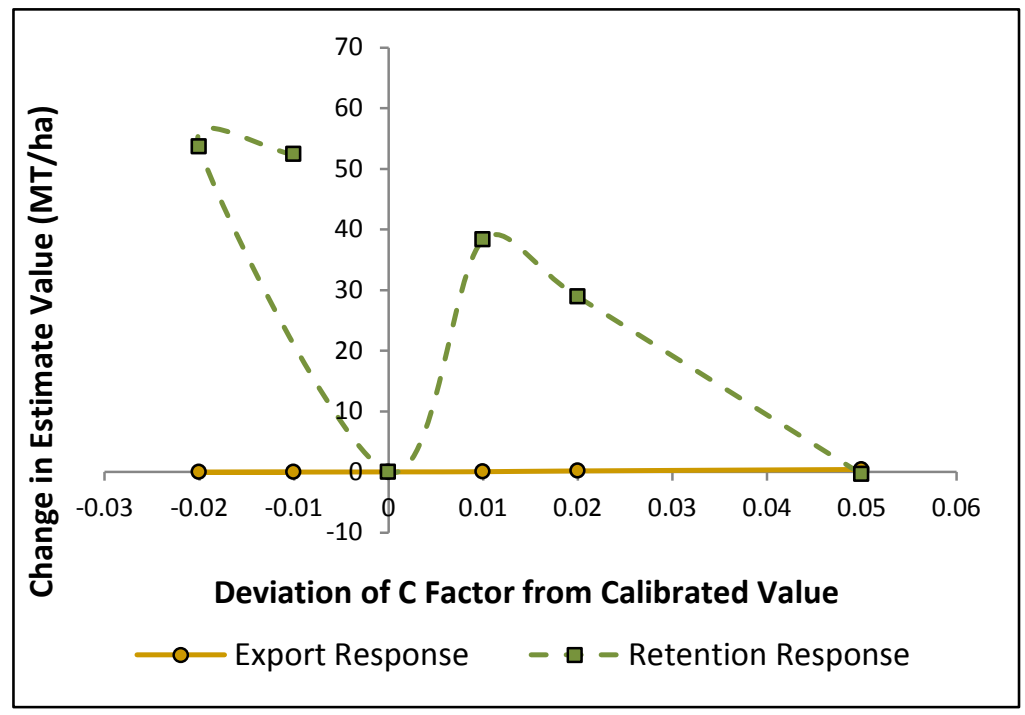

Figure 3.15

Results of C-factor sensitivity analysis for the InVEST sediment model. The $\mathrm{x}$-axis shows the change in the parameter from the calibrated value. The y-axis shows the response the per hectare estimate. The retention estimate show much greater sensitivity and non-linear effects. The Tualatin River at the West Linn gauge was the test basin for sensitivity. 
Table 3.10

Sensitivity analysis of parameters in the InVEST sediment retention model. Calibrated model for the Tualatin River at the West Linn gauge (14207500) was used as test basin. Parameters were adjusted to amount shown until the minimum or maximum was reached. (See Appendix B for description of parameters and model equations.)

\begin{tabular}{|c|c|c|c|}
\hline Parameter & Adjustment & $\begin{array}{l}\text { Export } \\
\text { Response } \\
\text { (MT/ha) }\end{array}$ & $\begin{array}{l}\text { Retention } \\
\text { Response } \\
\text { (MT/ha) }\end{array}$ \\
\hline \multirow{13}{*}{$\begin{array}{l}\text { Universal Soil Loss Equation (USLE) } \\
\text { Crop (C) Factor and Management (P) Factor } \\
\text { Min. } 0.001 \text { - Max. } 1\end{array}$} & $\mathrm{C}$ and $\mathrm{P}$ Down 0.01 & -0.086 & 4.29 \\
\hline & $\mathrm{C}$ and $\mathrm{P}$ Up 0.01 & 0.122 & -8.80 \\
\hline & $\mathrm{C}$ and $\mathrm{P}$ Up 0.05 & 0.839 & -42.33 \\
\hline & C Down 0.01 & -0.047 & 52.39 \\
\hline & C Down 0.02 & -0.053 & 53.62 \\
\hline & C Up 0.01 & 0.038 & 38.29 \\
\hline & C Up 0.02 & 0.163 & 28.88 \\
\hline & C Up 0.05 & 0.402 & -0.384 \\
\hline & P Down 0.01 & -0.038 & -0.238 \\
\hline & P Down 0.02 & -0.073 & -0.458 \\
\hline & P Up 0.01 & 0.037 & 0.240 \\
\hline & P Up 0.02 & 0.075 & 0.480 \\
\hline & P Up 0.05 & 0.187 & 1.198 \\
\hline \multirow{6}{*}{$\begin{array}{l}\text { Effective Retention (\%) } \\
\text { Min. } 0 \text { - Max. } 100\end{array}$} & Down 25 & 0.317 & -0.324 \\
\hline & Down 10 & 0.080 & -0.081 \\
\hline & Down 5 & 0.036 & -0.037 \\
\hline & Up 25 & -0.061 & 0.063 \\
\hline & Up 10 & -0.035 & 0.036 \\
\hline & Up 5 & -0.021 & 0.021 \\
\hline \multirow{4}{*}{$\begin{array}{l}\text { Length Slope Factor } \\
\text { (calibrated model set at default of 75) } \\
\text { Min. 1 - Max. } 100 \\
\text { Flow Threshold } \\
\text { (calibrated model set at 1300) } \\
\text { Min. 1 - Max. None }\end{array}$} & Down 20 & -0.012 & -45.99 \\
\hline & Up 20 & 0.018 & 55.46 \\
\hline & Down 800 & 0.056 & -12.76 \\
\hline & Up 800 & -0.025 & 7.79 \\
\hline
\end{tabular}

\section{Discussion}

There is a level of agreement in the ecosystem service research community that developing reliable and repeatable methods of quantifying and mapping ecosystem services is a major hurdle facing the effort to mainstream the ES approach in environmental and natural resource management (Crossman, Burkhard, et al., 2013; Martínez-Harms \& Balvanera, 2012). The Natural Capital Project's InVEST modeling 
environment is one initiative for addressing this problem. Using the ecological production function as the theoretical basis, it provides a way to address our research question as to how to map freshwater ecosystem services both spatially and temporally in our study area.

Our scenario maps offer a potential tool for determining what areas in the study area are most sensitive to potential LULC and climate change. It is clear that water supply is driven by climate with smaller land cover effects. Nutrient export and water purification services are largely driven by LULC, but there is potentially too much reliance on it. The amount of flow is a determinant in how much nutrients move across the landscape, and results suggest insensitivity to inter-annual and decadal variance in study area runoff patterns.

The assessment presented here does not place formal uncertainty bounds on the estimates presented in the results. Although InVEST was calibrated, asserting the estimates are accurate is still on tenuous ground especially without a measure of confidence to substantiate the claim. Spatially explicit ES assessments are subject to a multitude of uncertainties. Clear acknowledgement of the fact that ES are a product of a complex system evaluated with imperfect data and imperfect tools must be acknowledged by the producer of an assessment and the user of the information he or she provides. Hou, Burkhard, \& Müller (2013) point to original input data as the major source of uncertainty in ES assessments. This problem is then compounded by incomplete knowledge of the system represented by the model used for evaluation. This study illustrates the concerns involved in attempting to understand a complex problem nested within a complex system. 
With this in mind, the shortcomings that lead to uncertainty must be clearly communicated to managers in interested in the results. Identifying the assumptions and limitations needs to be a priority in order to still achieve a qualitative understanding of the study's caveats. We discuss the two sources of ES assessment error names by Hou et al. (2013), input data used, model structure.

Land use and land cover (LULC) data is never perfect product. Classification of landscapes constitutes a major source of uncertainty in any ecological assessment (Hou et al, 2013). NLCD's accuracy is high but does contain error especially in grass dominated categories, and assessments procedures are still developing (Wickham et al., 2013). Variation within a single LULC type is present, but considering there are currently no suggested parameter ranges for InVEST, it is difficult to justify using a more complex dataset as it could potentially introduce more parameter uncertainty. These issues make it inadvisable to interpret raster cell outputs of InVEST (Tallis et al., 2013). In our case, calibration suggests that the spatial scale of our sub-watershed units provides adequate aggregation to smooth this variation. However, there was still a perceived need to reclassify certain areas in the LULC dataset so that they may be parameterized differently, which is an approximate correction that can potentially introduce error as well. Another source of error may be derived from climate data input. The calibration climate dataset exhibits high correlation and minimal bias, but local scale effects still lead to error in climatic variables like minimum temperature (Abatzoglou, 2013). Errors in the climatic variables used in the modeling effort may potentially lead to poor estimates for 
water yield for some sub-watersheds, which may then be transferred to the scenario analysis.

Although our study area is relatively data rich, there are still gaps that impacted the analysis. In the Tualatin basin there were two stream gauging stations with a full flow record, and a relatively large water quality sampling profile. There was also sufficient data to develop estimates for the last decade of the study period for the urbanized Fanno Creek. Having more than one location in the basin for calibration allowed for a more spatially differentiated model. The Yamhill basin had much less nutrient concentration data than Tualatin, and it was located at only one station where simulated flow was necessary to develop load estimates. In only using the last fifteen years of the study period for the Yamhill which included the high flow years of the late 1990s, we are potentially enhancing their influence on the annual average estimates used to calibrate InVEST in a watershed already characterized with higher runoff. The much higher estimated nutrient loads exported to streams in the Yamhill as compared to the Tualatin is likely an artifact of this coupled with a larger agricultural land base. This may mean the assumption to increase the only agricultural land cover types export coefficients is incorrect.

The estimates for stream exports produced by LOADEST exhibit acceptable fit in most cases but there is uncertainty in the model's capability to predict daily loads. LOADEST methods are similar to the rating curve estimation approach used in a number of studies (Mattikalli \& Richards, 1996). Load based methods like the one used here require calculation of daily loads through a daily mean flow and a concentration sample, 
but flow is also an explanatory variable in the regression model. This can lead to spurious correlations exhibiting a strong relationship when in fact the relationship between flow and concentration is weak (Shivers \& Moglen, 2008). Another large assumption is that the model relationship of flow to load holds for values outside the training data range. This can lead to extrapolation error when a full estimate data range contains one or several very high flow events that may have reached a threshold where the relationships defined in the constructed model are no longer met.

The design of the InVEST tool set is based on tier process where higher tiered models exhibit higher degrees of complexity that enable outputs at finer temporal resolution, but require more data. The freshwater models used in this study are classified as tier one thus their outputs are potentially useful in absolute terms but they offer less utility in developing management strategies over more fine scale spatial targets within a management area (Kareiva, Tallis, Ricketts, Daily, \& Polasky, 2011). The InVEST development team is clear that some of their models are currently simple but conceptually sound, but we discuss these limitations within our analysis as a case study to articulate these issues more concretely.

Since they operate on an annual average, InVEST freshwater models are geared towards long term conditions. It is less equipped to deal with inter-annual variability of climate variables. One would have to make the assumption that if a scenario projection shows a wetter future annually, then flood risk is more likely. Low flow water quality is already an issue in our study area (Chang \& Lawler, 2011; Kelly, Lynch, \& Rounds, 1999). Managers are concerned with exacerbation of low flows in response to warmer 
temperatures and what will be the water quality and biological integrity response. If loads are projected to increase due to urbanization, is this response occurring mostly in the winter months or summer? These are questions that InVEST cannot yet address.

The water yield model has simple assumptions but leads to fairly accurate results. A fuller accounting of management activities like basin transfers and large withdrawals may improve the models performance slightly, but we are still capturing the overall characteristics of water yield in the study system. The water purification model relies on land cover to determine annual export flux of nutrients. Portions of the study area where no land cover change occurs see little to no change in exports or loads. Results suggest it is not sensitive to the water yield input in our study area (Table 3.5). This is problematic considering load estimates for calibration are based on flow.

The sensitivity analysis lends support to over reliance on the export coefficient parameter. The higher loads in the Yamhill basin require higher export coefficients, mainly attributed to agriculture. This is potentially a misspecification within the model, and would explain the counterintuitive result of export reductions caused by increased urbanization. If the hydrologic regime of the either basin is affected by climate change, they will not be seen in the results of the current model. So a portion of research question is not being addressed with this model. The load estimates reveal non-stationary patterns in stream loadings with a downward trend over the historical period. Much of this can be explained by decadal precipitation and runoff patterns, but terms based on time are also significant, suggesting a weak negative relationship between1981 and 2010 (see Appendix B for additional information). A complex interplay of climate, water quality 
regulations, LULC conversion, and best management practice (BMP) implementation are likely a factor too. This is the case in spite of a large increase in population within the study area. By assuming the parameterization for the historical period will hold for the scenarios, we are discounting the effect of these conditions could still improve over time. The erosivity variable does allow for climatic influence, which in our analysis proved to show large differences especially in the medium climate scenario that predicts high increases in winter rainfall. In particular, the sensitivity analysis reveals very large responses in the retention estimate to small changes in several of the parameters making its final estimate highly uncertain. The actual ecosystem service result of nutrient or sediment retention also appears to be highly contingent on how much exports are coming upslope. This fact seems to be supported by the correlations of nutrient export and retention, but not in sediment where other model mechanisms like the determination of the length slope factor are involved. The USLE method of estimating soil loss was developed at the field scale for agricultural fields. Transferring this method to effectively parameterize generalized land cover types across the landscape is a challenge given the spatial heterogeneity contained in each category.

Both models respond similarly when parameters driving exports are decreased, so does the level of retention. This can lead to misleading results where basins with the highest exports also contain the highest amounts of ecosystem services. In effect it is characterizing the service of retained mobilized nutrients and sediments, but not counting the effects of land cover and vegetation's ability to prevent mobilization. This part of the analysis suggests the great care should be taken in selecting percent retention values 
whose efficacy tends to decrease as the value is increased. Determining these values is difficult considering the lack of recommended ranges and the inherent assumption of uniform values over an entire land cover type.

Having acknowledged the limitations of the InVEST modeling framework, there is still much utility to be gained from its approach. The outputs are spatially explicit and can be mapped. Although fine scale location of management priorities is not feasible, overall patterns of ES on the landscape can be revealed, and thus aid in allocation of conservation resources. Here, the results suggest that at least at the landscape/regional scale used in this analysis, the provision of ES in the study will remain relatively stable. The only large shift occurs in sediment exports where certain sub-watersheds are projected to see a doubling or more of estimates. A large increase in urbanization near the mouth of the Tualatin also leads to high increases in nutrient exports. Other than these exceptions, changes are typically less than a third of current estimates. The bundling results also suggest a high level of spatial stability to the distribution of ES throughout the study area regardless of which scenario is used. There is also evidence the Yamhill basin provides a greater level of freshwater ES than the Tualatin (Figure 3.13), which would increase with riparian buffer installation. So InVEST can serve as a scoping tool and first approximate assessment of the ES profile in a study area. Sub-watersheds can be prioritized for further study or restoration. In this case, we suggest more examination of the potential for restoration in the Yamhill basin as it may have more impact of downstream water quality issues. Although not focused on nutrients, the Willamette TMDL does state thermal loads as a major concern. In the process of addressing the 
Yamhill's issues with riparian restoration efforts would also ameliorate the situation in the greater basin.

The modeling framework allows for a level of validation in terms of ES mapping. Unlike a complex process-based hydrologic modeling definition, we simply mean that the values created in the modeling effort are adjusted to reflect field observations. This provides some evidence that the processes that produce ecosystem services are being captured. InVEST allows for this step, which is a source of criticism in the majority of ES mapping projects that lack it (Martínez-Harms \& Balvanera, 2012; Schägner, Brander, Maes, \& Hartje, 2013; Seppelt, Dormann, Eppink, Lautenbach, \& Schmidt, 2011).

At its core, InVEST is a landscape planning tool and decision support system. Its estimates contain enough uncertainty to make their use in reaching regulatory targets questionable. It does allow for the assessment of trade-offs among ES, and does offer some tools to capture some of their value. From this perspective, it can offer much to those faced with land use decisions (Goldstein et al., 2010). The findings of our analysis suggest improvements to water quality by a large landscape wide increase in riparian vegetation. This is not necessarily a surprise finding, but we now haves spatially explicit information of the areal increase in natural vegetation needed to achieve a corresponding increase in the social benefit of enhanced water quality in the study area. Future research initiatives can proceed with spatially explicit estimation of the value of the ES benefits versus the costs associated with giving up that land's agricultural and residential value as function of return from rents. Johnson, Polasky, Nelson, \& Pennington (2012) showed that the benefits from increases in riparian vegetation in the Minnesota River Basin 
outweighed the losses incurred to returns from agricultural land. These researchers highlighted that uncertainty's in the value of ES and of commodity prices can lead to a change in the balance among tradeoffs. This is an analytical nuance where InVEST's ability to produce spatially explicit provision of ES estimates is extremely useful. Economic returns from land are also spatially variable. This will allow for a spatial targeting of where investment in enhancing ES provision is most cost effective. In our case the result of the individual ES maps along with the all three bundled suggest targeting sub-watersheds in the Yamhill basin for riparian restoration and ES enhancement would lead to the most gains in to water quality in relation to the entire Willamette Basin. Will targeting these areas also be the most cost effective areas as well? Future research questions like these have real potential to inform the design and implementation of incentive policies like PES or credit markets. If they are implemented and promote landscape-wide increases in riparian vegetation, there is real potential to mitigate urbanization and climate change effects. Where the capacity for restoration may be restricted for socioeconomic reasons, there is more risk for additional ES loss.

\section{Conclusions}

Using the modeling toolset InVEST offers several insights into the possible response of water related ecosystem services in the Tualatin and Yamhill Basins. Our scenario analysis is based on a few simple assumptions, but it incorporates both land cover and climate change into the assessment. Using both of these variables is not common in the ES mapping literature. We were able to map the freshwater ES in the 
study area at the landscape scale and gain insights into our research questions stated in the introduction.

(1) Water yields are projected to increase by as much a $22 \%$ for certain subwatershed in the medium climate scenario and decrease by as much as $11 \%$ in the high climate scenario. This is driven mainly by climate change, but urbanization and riparian buffer installation lead to some small changes in these areas too. Sub-watershed nutrient export changes are in the range of $\pm 30 \%$ with one exception. Retention changes from $-15 \%$ to $17 \%$. Nutrient exports and retention respond almost exclusively to land cover. High sensitivity to the export coefficients explains changes in the scenario maps. When natural vegetation is replaced, exports are increased and retention is reduced. When urban land cover types export more nutrients than what was replaced we observe a net export increase and retention as in the case of total phosphorus. Since export coefficients are of similar value for total nitrogen, but urban land cover is assigned slightly less retention, we observe increased exports and decreased retention. Sediment exports and retention are influenced by land cover and climate. The projected increase in winter rainfall leads to higher erosivity rates and is the main driver in a near across the board increase for both. The simulated management strategy of widespread use of riparian buffers has the effect of reducing exports and increasing retention rates in subwatersheds where they are placed. 
(2) The spatial distribution of freshwater ES remains relatively stable at the sub-watershed scale used in this analysis. There are some spatial characteristics to ES change in the scenarios. The lowland areas see more change in water yield in absolute terms than the highland portions of the study area. Nutrient exports increase in response to increased urban development in the Tualatin Basin. This is reversed in the Yamhill since urban land cover replaces agricultural lands with much higher nutrient export coefficients. Steeper areas of the study area have higher soil mobilization but also display high retention. The lowland agriculture and urban land cover have less retention capacity, producing a negative spatial correlation for the two. When the estimates are bundled into a weighted average, there is very little change in pattern of freshwater ES pattern amongst the scenarios. It does reveal the Yamhill basin providing more ES overall than the Tualatin basin.

(3) InVEST has limitations. The ecosystem service retention estimates go up with the increases in exports but do not account for the limits on the system's uptake potential. It contains a small number of parameters all of which display sensitivity, and have a large impact on the final ES estimate. With no recommended values, calibration can prove challenging and final estimates of ES contain much uncertainty. However, it gives the ability to calibrate to data from the study area, a step not typically seen in ES mapping projects. We argue this offers some credibility to the outputs 
especially in term of the relative change seen in freshwater ES. Also being spatially explicit, InVEST can help managers gain a landscape scale idea of where in a management area is providing the most ecosystem services.

This study leads to implications for both the burgeoning ES discipline, and the management of the study area. First, we attempt to elucidate some inherent limitations of using the InVEST approach to ES assessment at least with the available freshwater tools. After being transparent about the caveats, we suggest how the analysis can inform watershed management in study area.

The InVEST approach contains large uncertainties. Input data carry levels of uncertainty and empirical estimates used for calibration are subject to error. On one hand the modeling framework itself has simplifications that make it difficult to claim the simulation of important natural processes within the model captures the full complexity inherent in the system. That being said, the developers of InVEST acknowledge these issues and continue its development. On the other hand, these simplifications make it easier to approach, and can be viewed as a strength when data availability is limited (Vigorstol \& Aukema 2011).

The distribution of freshwater ES remains the same under the various scenarios. The results suggest that targeting the Yamhill for ES management will lead to greater downstream gains in water quality goals. InVEST offers much as a scenario planning tool. Our conclusion that riparian buffers will improve freshwater ES allows for a starting point on analyzing the tradeoffs to important provisioning services for the study area like 
timber, agricultural products, and residential land. Even with a large number of assumptions, this analysis still can provide relevant information and assist managers in understanding the potential patterns of freshwater ES of the Tualatin and Yamhill Basin in the future. 


\section{Conclusions}

This project aimed to address some of the challenges present in ecosystem service (ES) research. At the root of some of them is ecosystems display spatial and temporal heterogeneity therefore the services they provide do the same. Developing reliable ways to quantify and map ES is critical for giving the approach credibility. Additionally, projecting how these services might change under land use/land cover (LULC) and climate change has the potential for providing useful information to managers planning for an uncertain future. In the previous chapters, we presented results from an analysis attempting to address these research problems. We used the conceptual tool of scenario development and the modeling tool Integrated Valuation of Environmental Services and Tradeoffs (InVEST) to answer four research questions for two adjacent river systems in northwest Oregon. Can we develop a simple land change model relatively quickly and incorporate input from relevant stakeholders? Using InVEST, can we estimate the amount of freshwater services provided by our study area? Also can we use it to map their spatial distribution? Will this research further the understanding the utility of a method like InVEST for ES assessments?

In chapter two, we developed a simple land cover change model that incorporated some stakeholder input to project urban growth in the future centered on the year 2050 . We argue that its simplicity is advantageous in many respects. It is easier to communicate to a wide audience during planning efforts than other modeling approaches. The analysis is specific to our particular study area with the added input of stakeholders that identified land use regulations as the main driver of urban growth over the coming decades. The 
drawback is that with simplicity, there come large assumptions. We used population and simple demographic metrics to drive the amount of urban land cover added to the landscape. Other factors will certainly be at play. The three scenarios of low, medium, and high growth are useful, but don't capture the full spirit of scenario analyses where moderate to large diversions from the status quo should be present to account for surprise or unforeseen changes in the system (Peterson, Cumming, \& Carpenter, 2003).

Additionally, by just focusing on urban growth, the scope of the analysis was too limited as changes in other land types of our study area will likely occur. Additional development of this modeling technique would focus on this gap.

In the third chapter, we used InVEST to estimate the amount of water-related ES in the Tualatin and Yamhill basins, as well as map them to the sub-watershed scale. The major findings of this paper suggest water yield is largely a climate drive ecosystem service with subtle influences from land cover. Scenario maps reveal a tendency for yield estimates to be more stable in the upland areas with higher absolute changes occurring in the lowlands.

The water purification in the form of nutrient retention is correlated to the nutrient exports estimates InVEST produces. The LULC export coefficient is the most important parameter in the model. For example since much of the urban land cover in the Tualatin basin has a higher export coefficient than agriculture, it produces a pattern of both higher total phosphorus exports and retention for the sub-watersheds expected to see urban growth. The new urban growth does not retain as much total nitrogen as the LULCs it replaced but is exports a near equivalent amount thus there is an increase in exports and a 
reduction in retention. The Yamhill basin has a different parameterization with much higher exports for agriculture, resulting in the few sub-watersheds to see urban growth seeing across the board reductions. Sub-watersheds with little to no change see almost no changes in either exports or retention from the historic to future scenarios. The large scale installation of riparian buffers shows a large decline in exports and increase in retention with the assumption that riparian vegetation has a large capacity to retain nutrients.

The sediment model sees across the board increase in exports and thus across increases in retention from historic to future scenarios. This is attributed to climate change with respects to higher winter rainfall amounts. The spatial pattern of sediment exports and retention are negatively correlated. This is attributed to the landscape's topography and model parameterization. High slope areas have greater soil loss but high natural vegetation retention, whereas low slope areas have less mobilization of sediment, but the agricultural and urban land cover types present offer less retention capacity for what is mobilized. With the assumption that riparian buffer strips have high retention capacity, we see large reductions in exports and high retention estimates.

The datasets used in the modeling process are themselves simplified versions of reality and contain possible errors, which is major cause of uncertainty in ES assessments (Hou et al., 2012). This should be made transparent when interpreting the results. We discuss the specifics in the previous chapter. Through this analysis, we can point out some limitations of the InVEST freshwater models. All model parameters displayed sensitivity. Although we were able to calibrate to empirical estimates, the fact that there are no recommended value ranges mean that they totally user defined thus highly subject 
to user error. This leads to the possibility of misspecification in our InVEST models because of this. InVEST estimates are calculated at an annual time-step, and are further aggregated to an annual average. This is problematic for when management objectives are more relevant at a finer time scale, like climate change's effect on summer low flows. The biophysical processes simulated in InVEST are simplified. This can be useful for communication to stakeholders as with the LULC analysis, but again simplicity means large assumptions that obscure complexity. For instance, the over-reliance on land cover in the water purification model seems at first reasonable given the aggregation level of estimates. However given that we see high inter-annual and decadal variability in runoff, the land cover driven estimate may not hold if the hydrologic regime in the future study period is markedly different. Something we assume with climate change (Milly et al, 2008). The inherent assumptions made at the various steps in the analysis make it difficult to place quantifiable uncertainty bounds on the produced estimates. With this in mind, we have more confidence that InVEST is capturing relative change in freshwater ES, and have less faith in the absolute values presented in the scenario maps.

InVEST still is a useful tool given the limitations. With spatially explicit, mappable results, researchers and managers both can use it to start formulating more specific questions about the study area. Since InVEST requires relatively few inputs, it can provide a first level assessment that can aid in allocating conservation resources. We can use the results of our analysis to start an initial prioritization for further study or riparian restoration based on which sub-watersheds saw the highest export reductions. In this case, results suggest that the Yamhill basin is providing the most freshwater ES, and 
further improvement could help to alleviate downstream Willamette main-stem water quality issues. Furthermore this analysis provides a starting point for a tradeoff analysis that is spatially explicit. We now have an approximate quantification of the freshwater ES benefits of increased riparian vegetation. We can now ask more questions. What is the further benefit to wildlife habitat/biodiversity? What are the costs of giving up some land's agricultural production or its development potential? Coupled with a spatially explicit economic assessment, can we identify the most cost effective tradeoffs? These are important question that must be answered to make ES policy like payment for ecosystem services or credit markets a working solution to environmental problems.

This project answered the research questions posed at the start of this thesis successfully but with caveats. We produced a set of three future land cover scenarios. We carefully documented the methods and stated the assumptions of the analysis, and delivered a usable product. We have presented a series of scenarios showing the potential changes to the amount of freshwater ES in the Tualatin and Yamhill basins. We argue that the information provides relevant information and an initial step in an ES assessment of the study area. We offer a discussion of some the issues of the approach and attempt to make transparent the limits to its utility. By using the InVEST tool, we have a greater understanding of the structure of its freshwater toolset. We discuss the usefulness and caveats of the tools that will be informative to researchers and managers who may have interest in using it. Finally, this research provides a contribution to the growing body of work on water-related ecosystem services and offers new information to this emerging interdisciplinary approach. 


\section{References}

Abatzoglou, J. T. (2013). Development of gridded surface meteorological data for ecological applications and modelling. International Journal of Climatology, 33, 121-131. doi:10.1002/joc.3413

Abatzoglou, J. T., \& Brown, T. J. (2012). A comparison of statistical downscaling methods suited for wildfire applications. International Journal of Climatology, 32, 772-780. doi:10.1002/joc.2312

Abbot, C., Howe, D., \& Adler, S. (Eds.). (1994). Planning the Oregon way: A twentyyear evaluation. Corvallis: Oregon State University Press.

Abrams, M. M., \& Jarrell, W. M. (1995). Soil phosphorus as a potential nonpoint source for elevated stream phosphorus levels. Journal of Environmental Quality, 24(1), 132-138. doi:10.2134/jeq1995.00472425002400010019x

Arnold, J. G., Moriasi, D. N., Gassman, P. W., Abbaspour, K. C., White, M. J., Srinivasan, R., Santhi, C., Harmel, R. D., van Griensven, A., Van Liew, M. W., Kannan, N., \& Jha, M. K. (2012). SWAT: Model use, calibration, and validation. Transaction of the American Society of Agricultural and Biological Engineers, 55(4), 1491-1508.

Bai, Y., Zhuang, C., Ouyang, Z., Zheng, H., \& Jiang, B. (2011). Spatial characteristics between biodiversity and ecosystem services in a human-dominated watershed. Ecological Complexity, 8(2), 177-183. doi:10.1016/j.ecocom.2011.01.007

Bateman, I. J., Harwood, A. R., Mace, G. M., Watson, R. T. , Abson, D. J., Andrews, B., Binner, A., Crowe, A., Day B. H., Dugdale, S., Fezzi, C., Foden, J., Hadley, D., Haines-Young, R., Hulme, M., Kontoleon, A., Lovett, A. A., Munday, P., Pascual, U., Paterson, J., Perino, G., Sen, A., Siriwardena, G., van Soest, D., \& Termansen, M. (2013). Bringing ecosystem services into economic decisionmaking: Land use in the United Kingdom. Science, 341(45), 45-50. doi:10.1126/science. 1234379

Boeder, M. \& Chang, H. (2008). Multi-scale analysis of oxygen demand trends in an urbanizing Oregon watershed, USA. Journal of Environmental Management, 87(4), 567-581. doi:10.1016/j.jenvman.2007.12.009

Boody, G., Vondracek, B., Andow, D. A., Krinke, M., Westra, J., Zimmerman, J., \& Welle, P. (2005). Multifunctional agriculture in the United States. BioScience, 55(1), 27-38. doi:10.1641/0006-3568(2005)055[0027:MAITUS]2.0.CO;2 
Booth, D. B., Hartley, D., \& Jackson, R. (2002). Forest cover, impervious-surface area, and the mitigation of stormwater impacts. Journal of the American Water Resources Association, 38(3), 835-845. doi:10.1111/j.1752-1688.2002.tb01000.x

Brauman, K. A., Daily, G. C., Duarte, T. K., \& Mooney, H. A. (2007). The nature and value of ecosystem services: An overview highlighting hydrologic services. Annual Review of Environment and Resources, 32, 67-98. doi:10.1146/annurev.energy.32.031306.102758

Burkhard, B., de Groot, R., Costanza, R., Seppelt, R., Jørgensen, S. E., \& Potschin, M. (2012). Solutions for sustaining natural capital and ecosystem services.

Ecological Indicators, 21, 1-6. doi:10.1016/j.ecolind.2012.03.008

Chan, K. M. A., Shaw, M. R., Cameron, D. R., Underwood, E. C., \& Daily, G.C. (2006). Conservation planning for ecosystem services. Plos Biology, 4, 2138-2152. doi:10.1371/journal.pbio.0040379

Chang, H. and Lawler, K. (2011). Impacts of climate variability and change on water temperature in an urbanizing Oregon basin. In Peters, N. E., Krysanova, V., Lepisto, A., Prasad, R., Thoms, M. C., Wilby, R., Zandaryaa, S. (Eds.), Water quality: Current trends and expected climate impacts (123-128). Oxfordshire: IAHS Publication 348.

Cochran, B., \& Logue, C. (2011). A watershed approach to improve water quality: A case study of Clean Water Services' Tualatin River program. Journal of the American Water Resources Association, 47(1), 29-38. doi:10.1111/j.17521688.2010.0049.x

Costanza, R., D’Arge, R., de Groot, R., Farber, S., Grasso, M., Hannon, B., Limburg, K., Naeem, S., O’Neill, R. V., Paruelo, J., Raskins, R. G., Sutton, P., \& van der Belt, M. (1997). The value of the world's ecosystem services and natural capital. Nature, 387, 253-260.

Crossman, N. D., Bryan, B. A., de Groot, R. S., Lin Y., \& Minang, P. A. (2013). Land science contributions to ecosystem services. Current Opinion in Environmental Sustainability, 5(5), 509-514. doi:10.1016/j.cosust.2013.06.003

Crossman, N. D., Burkhard, B., Nedkov, S., Willemen, L., Petz, K., Palomo, I., Drakou, E. G., Martín-Lopez, B., McPhearson, T., Boyanova, K., Alkemade, R., Egoh, B., Dunbar, M. B., \& Maes, J. (2013). A blueprint for mapping and modelling ecosystem services. Ecosystem Services, 4, 4-14. doi:10.1016/j.ecoser.2013.02.001 
Daily, G. C. (Ed.) (1997). Nature's services: Societal dependence on natural ecosystems. Washington D.C.: Island Press.

Daily, G. C., Polasky, S., Goldstein, J., Kareiva, P. M., Mooney, H. A., Pejchar, L., Ricketts, T. H., Salzman, J., \& Shallenberger, R. (2009). Ecosystem services in decision making: Time to deliver. Frontiers in Ecology and the Environment, 7(1), 21-28 doi: $10.1890 / 080025$

de Groot, R. S., Wilson, M. A., \& Boumans, R. M. (2002). A typology for the classification, description and valuation of ecosystem functions, goods and services. Ecological Economics, 41(3), 393-408. doi:10.1016/S09218009(02)00089-7

de Groot, R. S., Alkemade, R., Braat, L., Hein, L., \& Willemen, L. (2010). Challenges in integrating the concept of ecosystem services and values in landscape planning, management and decision making. Ecological Complexity, 7(3), 260-272. doi:10.1016/j.ecocom.2009.10.006

Eade, J. D. O., \& Moran, D. (1996). Spatial economic valuation: Benefits transfer using geographic information systems. Journal of Environmental Management, 4, 91110. doi:10.1006/jema.1996.9990

Egoh, B., Reyers, B., Rouget, M., Richardson, D., Lemaitre, D., \& van Jaarsveld, A. S. (2008). Mapping ecosystem services for planning and management. Agriculture, Ecosystems \& Environment, 127, 135-140. doi:10.1016/j.agee.2008.03.013

EPA (U.S. Environmental Protection Agency). (2009). Valuing the protection of ecological systems and services: A report of the EPA science advisory board (EPA publication EPA-SAB-09-012). http://yosemite.epa.gov/sab/sabproduct.nsf/WebBOARD/ValProtEcolSys\&Serv

ESRI (Environmental Science Research Institute). (2010). ArcGIS 10.0. [Software] Redlands, CA, U.S.A.

Foley, J. A., DeFries, R., Asner, G. P., Barford, C., Bonan, G., Carpenter, S. R., Chapin F. S., Coe, M. T., Daily, G. C., Gibbs, H. K., Helkowski, J. H., Holloway, T., Howard, E. A., Kucharik, C. J., Monfreda, C., Patz, J. A., Prentice, I. C., Ramankutty, N., \& Snyder, P. K. (2005). Global consequences of land use. Science, 309, 570-574. doi:10.1126/science. 1111772

Folke, C., Carpenter, S., Elmqvist, T., Gunderson, L., Holling, C. S., \& Walker, B. (2002). Resilience and sustainable development: Building adaptive capacity in a world of transformations. Ambio, 31(5), 437-440. doi:10.1579/0044-744731.5.437 
Fry, J., Xian, G., Jin, S., Dewitz, J., Homer, C., Yang, L., Barnes, C., Herold, N., \& Wickham, J. (2011). Completion of the 2006 National Land Cover Database for the conterminous United States. PE\&RS, 77(9), 858-864.

Goldstein, J. H., Caldarone, G., Duarte, T. K., Ennaanay, D., Hannahs, N., Mendoza, G., Polasky, S., Wolny, S., \& Daily G. C. (2012). Integrating ecosystem-service tradeoffs into land-use decisions. Proceedings of the National Academy of Sciences of the United States of America, 109(19), 7565-7570. doi:10.1073/pnas.1201040109

Gulickx, M. M. C., Verburg, P. H., Stoorvogel, J. J., Kok, K., \& Veldkamp, A. (2013). Mapping landscape services: A case study in a multifunctional rural landscape in the Netherlands. Ecological Indicators, 24, 273-283. doi:10.1016/j.ecolind.2012.07.005

Hauck, J., Görg, C., Varjopuro, R., Ratamäki, O., \& Jax, K. (2013). Benefits and limitations of the ecosystem services concept in environmental policy and decision making: Some stakeholder perspectives. Environmental Science \& Policy, 25, 13-21. doi:1016/j.envsci.2012.08.001

Hauck, J., Görg, C., Varjopuro, R., Ratamäki, O., Maes, J., Wittmer, H., \& Jax, K. (2013). "Maps have an air of authority": Potential benefits and challenges of ecosystem service maps at different levels of decision making. Ecosystem Services, 4, 25-32. doi:10.1016/j.ecoser.2012.11.003

Holman-Dodds, J. K., Bradley, A. A., \& Potter, K. W. (2003). Evaluation of hydrologic benefits of infiltration based urban storm water management. Journal of the American Water Resources Association, 39(1), 205-215. doi:10.1111/j.17521688.2003.tb01572.x

Hou, Y., Burkhard, B., \& Müller, F. (2013). Uncertainties in landscape analysis and ecosystem service assessment. Journal of Environmental Management, 127, S117S131. doi:10.1016/j.envman.2012.12.002

Hulse, D. W., Branscomb, A., \& Payne, S. G. (2004). Envisioning alternatives: Using citizen guidance to map future land and water use. Ecological Applications, 14(2), 325-341. doi:10.1890/02-5260

IPCC (Intergovernmental Panel on Climate Change). (2007). Climate change 2007: Synthesis report. Contribution of Working Groups I, II, III to the Fourth Assessment Report of the Intergovernmental Panel on Climate Change [Core writing team, Pachauri, R. K., \& Reisinger, A. (Eds.)]. Geneva: Switzerland. 
Jack, B. K., Kousky, C., \& Sims K. R. E. (2008). Designing payments for ecosystem services: lessons from previous experience with incentive-based mechanisms. Proceedings of the National Academy of Sciences of the United States of America, 105(28), 9465-9470. doi:10.1073/pnas.0705503104

Johnson, K. A., Polasky, S., Nelson, E., \& Pennington, D. (2012). Uncertainty in ecosystem services valuation and implication for assessing land use tradeoffs: An agricultural case study in the Minnesota River Basin. Ecological Economics, 79, 71-79. doi:10.106/j.ecolecon.2012.04.020

Johnson, L. B., Richards, C., Host, G. E., \& Arthur, J. W. (1997). Landscape influences on water chemistry in Midwestern stream ecosystems. Freshwater Biology, 37, 193-208. doi:10.1046/j.1365-2427.1997.d01-539.x

Kareiva, P., Tallis, H., Ricketts, T. H., Daily, G. C., \& Polasky, S. (Eds.) (2011). Natural capital: Theory \& practice for mapping ecosystem services. Oxford: Oxford University Press

Koschke, L., Fürst, C., Frank, S., \& Makeschin, F. (2012). A multi-criteria approach for an integrated land-cover-based assessment of ecosystem services provision to support landscape planning. Ecological Indicators, 21, 54-66. doi:10.106/j.ecolind.2011.12.010

Kelly, V. J., Lynch, D. D., \& Rounds, S. A. (1999). Sources and transport of phosphorus and nitrogen during low-flow conditions in the Tualatin River, Oregon, 19911993. (United States Geological Survey Water-Supply Paper 2465-C). http://pubs.er.usgs.gov/publication/wsp2465C

Lautenbach, S., Kegel, C., Lausch, A., \& Seppelt, R. (2011). Analysis of historic changes in regional ecosystem service provisioning using land use data. Ecological Indicators, 11, 676-687. doi:10.1016/j.ecolind.2010.09.007

Liu, J., Dietz, T., Carpenter, S. R., Alberti, M., Folke, C., Moran, E., Pell, A. N., Deadman, P., Kratz, T., Lubchenco, J., Ostrom, E., Ouynag, Z., Provencher, W., Redman, C. L., Schneider, S. H., \& Taylor, W. W. (2007). Complexity of coupled human and natural systems. Science, 317, 1513 - 1516. doi:

$10.1126 /$ science. 1144004

Lockie, S. (2013). Market instruments, ecosystem services, and property rights: assumptions and conditions for sustained social and ecological benefits. Land Use Policy, 31, 90-98. doi:10.1016/j.landusepol.2011.08.010 
Martínez-Harms, M. J. \& Balvanera, P. (2012). Methods for mapping ecosystem service supply: a review. International Journal of Biodiversity Science, Ecosystem Services \& Management, 8(1-2), 17-25. doi:10.1080/21513732.2012.663792

Mattakalli, N. M., \& Richards, K. S. (1996). Estimation of surface water quality changes in response to land use change: Application of the export coefficient model using remote sensing and geographical information. Journal of Environmental Management, 48(3), 262-282. doi:dx.doi.org/10.1006/jema.1996.0077

MA (Millennium Ecosystem Assessment). (2005). Ecosystems and Human Well-Being. Washington, DC: Island Press.

Milly, P. C. D., Betancourt, J., Falkenmark, M., Hirsch, R. M., Kundzewicz, Z. W., Lettenmaier, D. P., \& Stouffer, R. J. (2008). Stationary is dead: Whither water management? Science, 319, 573 -574. doi: 10.1126/science.1151915

NHDplus V2 (National Hydrography Dataset Plus Version 2). (2013). Pacific Northwest [Data file]. Retrieved from http://www.horizonsystems.com/NHDPlus/NHDPlusV2_17.php

NWIS (National Water Information System). (2013).USGS Surface-water daily data for the nation [Data file]. Retrieved from http://waterdata.usgs.gov/nwis/dv/?referred_module $=\mathrm{sw}$

Nearing, M. A. (2001). Potential changes in rainfall erosivity in the U.S. with climate change during the $21^{\text {st }}$ century. Journal of Soil and Water Conservation, 56(3): 229-232.

Nelson, E., Mendoza, G., Regetz, J., Polasky, S., Tallis, H., Richard, D., Chan, K. M. A., Daily, G. C., Goldstein, J., Kareiva, P. Lonsdorf, E., Naidoo, R., Ricketts, T. H., \& Shaw, M. R. (2009). Modeling ecosystems services, biodiversity conservation, commodity production, and tradeoffs at landscape scales. Frontiers in Ecology and the Environment, 7(1), 4-11 doi:10.1890/080023

Nelson, E. J., \& Daily, G .C. (2010). Modelling ecosystem services in terrestrial systems. F1000 Biology Reports, 2, 53. doi:10.3410/B2-53

Nelson, E., Sander, H., Hawthorne, P., Conte, M., Ennaanay, D., Wolny, S., Manson, S., \& Polasky, S. (2010). Projecting global land-use change and its effect on ecosystem service provision and biodiversity with simple models. PLoS ONE, 5(12), e14327. doi:10.1371/journal.pone0014327 
Oberndorfer, E., Lundholm, J., Bass, B., Coffman, R. R., Doshi, H., Dunnett, N., Gaffin, S., Köhler, M., Liu, K. K. Y., \& Rowe, B. (2007). Green roofs as urban ecosystems: Ecological structures, functions, and services. BioScience, 57(10), 823-833. doi:10.1641/B571005

Oregon Blue Book. (2011). City and County Populations. Retrieved from http://bluebook.state.or.us/local/populations/populations.htm

ODEQ (Oregon Department of Environmental Quality). (2006). Willamette Basin TMDL: Chapter 1: Overview. Retrieved from http://www.deq.state.or.us/wq/tmdls/docs/willamettebasin/willamette/chpt1overvi ew.pdf

ODEQ (Oregon Department of Environmental Quality). (2012). Tualatin subbasin total maximum daily load and water quality management plan: Chapter 1 -overview and background. Retrieved from http://www.deq.state.or.us/wq/tmdls/docs/willamettebasin/tualatin/revision/Ch0C overExecSummary.pdf

ODEQ (Oregon Department of Environmental Quality). (n.d).Water quality: Oregon drinking water protection program. Retrieved from http://www.deq.state.or.us/wq/dwp/swrpts.asp

ODLCD (Oregon Department of Land Conservation and Development). (2011). Ballot measures 37(2004) and 49 (2007) outcomes and effects. Retrieved from http://www.oregon.gov/LCD/docs/publications/m49_2011-01-31.pdf

ODLCD (Oregon Department of Land Conservation and Development). (2013). Metro Urban and Rural Reserves. Retrieved from http://www.oregon.gov/LCD/Pages/metro_urban_and_rural_reserves.aspx

Oregon Metro. (2009). 20 and 50 year regional employment and population range forecasts. Retrieved from http://library.oregonmetro.gov/files/2050_range_forecast.pdf

Oregon State Archives. (2012). Department of land conservation and development. Division 33. Agricultural land. Retrieved from http://arcweb.sos.state.or.us/pages/rules/oars_600/oar_660/660_033.html

OWRD (Oregon Water Resources Department). (n.d.) Water Protections and Restrictions. Retrieved from http://www.oregon.gov/owrd/pages/pubs/aquabook_protections.aspx 
OWRD (Oregon Water Resources Department). (2013). Historical streamflow and lake level data [Data file]. Retrieved from http://apps.wrd.state.or.us/apps/sw/hydro_report/

Parker, D. C., Manson, S. M., Janssen, M. A., Hoffman, M. J., \& Deadman, P. (2003). Multi-agent systems for the simulation of land-use and land-cover change: a review. Annals of the Association of American Geographers, 93(2), 314-337. doi:10.1111/1467-8306.9302004

Paul, M. J., \& Meyer, J. L. (2001). Streams in the urban landscape. Annual Review of Ecology and Systematics, 32, 333-365.

Peterson, G. D., Cumming, G. S., \& Carpenter, S. R. (2003). Scenario planning: A tool for conservation in an uncertain world. Conservation Biology, 17(2), 385-366. doi:10.1046/j.1523-1739.2003.01491.x

Polasky, S., Nelson, E., Pennington, D., \& Johnson, K. A. (2011). The impact of land-use change on ecosystem services, biodiversity and returns to landowners: A case study in the state of Minnesota. Environmental Resource Economics, 48, 219 242. doi:10.1007/s10640-010-9407-0

Portland State University College of Urban and Public Affairs Population Research Center. (2013) Population Estimates [Data file]. Retrieved from http://www.pdx.edu/prc/population-estimates-0

Praskievicz, S. \& Chang, H. (2011). Impacts of climate change and urban development on water resources in the Tualatin River basin, Oregon. Annals of the Association of American Geographers, 101, 249-271. doi:10.1080/00045608.2010.544934

Price, J., Silbernagel, J., Miller, N., Swaty, R., White, M., \& Nixon, K. (2012). Eliciting expert knowledge to inform landscape modeling of conservation scenarios. Ecological Modelling, 229, 76-87. doi:10.1016/j.ecolmodel.2011.09.010

Radeloff, V. C., Nelson, E., Plantinga, A. J., Lewis, D. J., Helmers, D., Lawler, J. J., Withey, J. C., Beaudrey, R., Martinuzzi, S., Butsic, V., Lonsdorf, E., White, D., \& Polasky, S. (2012). Economic-based projections of future land use in the coterminous Unites States under alternative policy scenarios. Ecological Applications, 22(3), 1036-1049. doi:10.1890/11-0306.1

Raudsepp-Hearne, C., Peterson, G. D., \& Bennet, E. M. (2010). Ecosystem service bundles for analyzing tradeoffs in diverse landscapes. Proceeding of the National Academy of Sciences of the United of the States of America, 107(11), 5242-5247. doi:10.1073/pnas.9097284107 
Renard, K. G., \& Freimund, J. R. (1994). Using Monthly precipitation data to estimate the R factor in the revised USLE. Journal of Hydrology, 157, 287-306. doi:10.1016/0022-1694(94)90110-4

Renard, K. G., Foster, G. R., Weesies, G. A., McCool, D. K., \& Yoder, D. C. (1997). Predicting soil erosion by water: A guide to conservation planning with the Revised Soil Loss Equation (RUSLE) (U.S. Department of Agriculture, Agriculture Handbook No. 703). http://www.epa.gov/npdes/pubs/ruslech2.pdf

Rockström, J., Steffen, W., Noone, K. Persson, Å., Chapin III, F. S., Lambin, E. F., Lenton, T. M., Scheffer, M., Folke, C., Schellnhuber, H. J., Nykvist, B., de Wit, C. A., Hughes, T., van der Leeuw, S., Rodhe, H., Sörlin, S., Snyder, P.K., Costanza, R., Svedin, U., Falkenmark, M., Karlberg, L., Corell, R. W., Fabry, V. J., Hansen, J., Walker, B., Liverman, D., Richardson, K., Crutzen, P., \& Foley, J. A. (2009). A safe operating space for humanity. Nature, 461(7263): 472-475. doi:10.1038/461472a

Rounds, S. A., Woods, T. M., \& Lynch, D. D. (1999). Modeling discharge, temperature, and water quality in the Tualatin River, Oregon (United States Geological Survey Water Supply Paper 2465-B.) http://pubs.er.usgs.gov/publication/wsp2465B

Ruckelshaus, M., McKenzie, E., Tallis, H., Guerry, A., Daily, G., Kareiva, P. Polasky, S., Ricketts, T., Bhagabati, N., Wood, S. A., Bemhardt, J. (2013). Notes from the field: Lessons learned from using ecosystem service approaches to inform realworld decisions. Ecological Economics, Advanced Online Publication. doi:10.1016/j.ecolecon.2013.07.009

Runkel, R. L., Crawford, C. G., \& Cohn, T. A. (2004). Load Estimator (LOADEST): A Fortran program for estimating constituent loads in streams and rivers (US Geological Survey Techniques and Methods: 4-A.) http://pubs.usgs.gov/tm/2005/tm4A5/

Saaty, T.L. (1980). The analytic hierarchy process: planning, priority setting, resource allocation. New York: McGraw-Hill.

Santelmann, M. V., White, D., Freemark, K., Nassauer, J. I., Eilers, J. M., Vaché, K. B., Danielson, B. J., Corry, R. C., Clark, M. E,. Polasky, S., Cruse, R. M., Sifneos, J., Rustigian, H., Coiner, C., Wu, J., \& Debinski D. (2004). Assessing alternative futures for agriculture in Iowa, U.S.A. Landscape Ecology, 19(4), 357-374. doi:10.1023/B:LAND.0000030459.43445.19

Schägner, J. P., Brander, L., Maes, J., \& Hartje, V. (2013). Mapping ecosystem services' values: Current practice and future prospects. Ecosystem Services, 4, 33-46. doi:10.1016/j.ecoser.2013.02.003 
Seppelt, R., Dormann, C. F., Eppink, F. V., Lautenbach, S., \& Schmidt, S. (2011). A quantitative review of ecosystem service studies: approaches, shortcomings and the road ahead. Journal of Applied Ecology, 48, 630-636. doi:10.1111/j.13652664.2010.01952.x

Seto, K. C., Güneralp, B., \& Hutyra, L. (2012). Global forecasts of urban expansion to 2030 and direct impacts on biodiversity and carbon pools. Proceedings of the National Academy of Sciences of the United States of America, 109(40), 1608316088. doi:10.1073/pnas.1211658109

Shivers, D. E., \& Moglen, G. E. Spurious correlation in the USEPA rating curve method for estimating pollutant loads. Journal of Environmental Engineering, 134(8), 610-618. doi:10.1061/(ASCE)0733-9372(2008)134:8(610)

Smith, N., Deal, R., Kline, J., Blahna, D., Patterson, T., Spies, T. A., \& Bennet, K. (2011). Ecosystem services as framework for forest stewardship: Deschutes National Forest Overview (USDA Forest Service General Technical Report. PNW-GTR-852).

Southworth, J., Marsik, M., Qiu, Y., Perz, S., Cumming, G., Stevens, F., Rocha, K., Duchelle, A., \& Barnes, G. (2011). Roads as drivers of change: Trajectories across the Tri-National Frontier in MAP, the Southwestern Amazon. Remote Sensing, 3(5), 1047-1066. doi:10.3390/rs3051047

Staudinger, M. D., Grimm, N. B., Staudt, A., Carter, S. L., Chapin III, F. S., Kareiva, P., Ruckelshaus, M., \& Stein, B. A. (2012). Impacts of Climate Change on Biodiversity, Ecosystems, and Ecosystem Services: Technical Input to the 2013 National Climate Assessment (Cooperative Report to the 2013 National Climate Assessment). http://assessment.globalchange.gov

Su, S., Xiao, R., Jiang, Z., \& Zhang, Y. (2012). Characterizing landscape pattern and ecosystem service value changes for urbanization impacts at an eco-regional scale. Applied Geography, 34, 295-305. doi:10.1016/j.apgeog.2011.12.001

Suarez-Rubio, M., Lookingbill, T. R., \& Wainger, L. A. (2012). Modeling exurban development near Washington, DC, USA: comparison of a pattern based model and spatially-explicit econometric model. Landscape Ecology, 27(7), 1045-1061. doi:10.1007/s10980-012-9760-1

Swetnam, R. D., Fisher, B., Mbilinyi, B. P., Munishi, P. K. T, Willcock, S., Ricketts, T., Mwakalila, S., Balmford, A., Burgess, N. D., Marshall, A. R., \& Lewis, S. L. (2011). Mapping socio-economic scenarios of land cover change: A GIS method to enable ecosystem service modelling. Journal of Environmental Management, 92, 563-574. doi:10.1016/j.jenvman.2010.09.007 
Tallis, H., \& Polasky, S. (2009). Mapping and valuing ecosystem services as an approach for conservation and natural-resource management. Annals of the New York Academy of Sciences, 1162, 265-283. doi:10.1111/j.1749-6632.2009.04152.x

Tallis, H. T., Ricketts, T., Guerry, A. D.,Wood, S. A., Sharp, R., Nelson, E., Ennaanay, D.,Wolny, S., Olwero, N., Vigerstol, K., Pennington, D., Mendoza, G., Aukema, J., Foster, J., Forrest, J., Cameron, D., Arkema, K., Lonsdorf, E., Kennedy, C., Verutes, G., Kim, C.K., Guannel, G., Papenfus, M., Toft, J., Marsik, M., Bernhardt, J., \& Griffin, R. (2013). InVEST 2.5.3 User's Guide. The Natural Capital Project, Stanford. http: $\|_{w w w}$.naturalcapitalproject.org

Taylor, K. E., Stouffer, R. J., \& Meehl, G. A. (2012). An Overview of the CMIP5 and the Experiment Design. Bulletin of the American Meteorological Society, 93(4), 485498. doi:10.1175/BAMS-D-11-00094.1

Terrado, M., Acuña, V., Ennaanay, D., Tallis, H., \& Sabater, S. (2013). Impact of climate extremes on hydrological ecosystem services in a heavily humanized Mediterranean basin. Ecological Indicators, Advanced Online Publication. doi:10.1016/j.ecolind.2013.01016

Thompson, J. R., Wiek, A., Swanson, F. J., Carpenter, S. R., Hollingsworth, T., Spies, T. A., \& Foster, D. R. (2012). Scenario studies as a synthetic and integrative research activity for long-term ecological research. BioScience, 62(4), 367-376. doi:10.1525/bio.2012.62.4.8

Troy, A., \& Wilson, M. (2006). Mapping ecosystem services: Practical challenges and opportunities in linking GIS and value transfer. Ecological Economics, 60(2), 435-449. doi:10.1016/j.ecolecon.2006.04.007

Turner, B. L., Lambin, E. F., \& Reenberg, A. (2007). The emergence of land change science for global environmental change and sustainability. Proceedings of the National Academy of Sciences of the United States of America, 104(52), 2066620671. doi:10.1073/pnas.0704119104

U.S. Bureau of Labor Statistics. (2013). Local Area Employment Statistics, U.S. Department of Labor [Data file]. Retrieved from http://data.bls.gov/cgi-bin/dsrv

U.S. Census Bureau. (2010). Profile of General Population and Housing Characteristics: 2010. Geography: Portland-Vancouver-Hillsboro, OR-WA Metro Area (part); Oregon [Data file]. Retrieved from http://factfinder2.census.gov/faces/tableservices/jsf/pages/productview.xhtml?pid =DEC_10_DP_DPDP1\&prodType=table 
Vigorstol, K. L., \& Aukema, J. E. (2011). A comparison of tools for modeling freshwater ecosystem services. Journal of Environmental Management, 92, 2403-2409. doi: 10.1016/j.jenvman.2011.06.040

Vitousek, P., Mooney H., Lubchenco J., \& Melillo J. (1997). Human domination of Earth's ecosystems. Science, 277(5325), 494-499. doi:10.1126/science.277.5325.494

Waldhardt, R., Bach, M., Borresch, R., Breuer, L., Diekötter, T., Frede, H., Gäth, S., Ginzler, O., Gottschalk, T., Julich, S., Krumpholz, M., Kuhlmann, F., Otte, A., Reger, B., Reiher, W., Schmitz, K., Schmitz, P. M., Sheridan, P., Simmering, D., Weist, C., Wolters, V., \& Zörner, D. (2010). Evaluating today's landscape multifunctionality and providing an alternative future : A normative scenario approach. Ecology and Society, 15(3).

Walker, P. A., \& Hurley, P. T. (2011). Planning paradise: Politics and visioning of land use in Oregon. Tucson: The University of Arizona Press.

Walsh, C. J., Fletcher, T. D. \& Ladson, A. R. (2005). Stream restoration in urban catchments through redesigning stormwater systems : looking to the catchment to save the stream. Journal of the North American Benthological Society, 24(3), 690-705. doi:10.1899/04-020.1

Westervelt, J., BenDor, T., \& Sexton, J. (2011). A technique for rapidly forecasting regional urban growth. Environment and Planning B: Planning and Design, 38, 61-81. doi:10.1068/b36029

Wickham, J. D., Stehman, S. V., Gass, L., Dewitz, J., Fry, J. A., \& Wade, T. G. (2013). Accuracy assessment of NLCD 2006 land cover and impervious surface. Remote Sensing of Environment, 130, 294-304. doi:10.1016/j.rse.2012.12.001

Wischmeier, W. H., \& Smith, D. (1978). Predicting rainfall erosion losses: a guide to conservation planning (USDA - ARS Agriculture Handbook, Washington D.C).

Zhang, L., Dawes, W. R. \& Walker, G. R. (2001). Response of mean annual evapotranspiration to vegetation change at a catchment scale. Water Resources Research, 37(3), 701-708. doi:10.1029/2000WR900325 
Appendix A: Chapter II Supplementary, Geoprocessing and Scripting Methods

\section{A.1 Geoprocessing}

Since land use/land cover (LULC) is typically represented is the raster data model, the geoprocessing routine developed for new urban growth assignment relies heavily on ArcGIS's spatial analyst extension toolset.

Starting with an USGS National Land Cover Dataset (NLCD) raster, the first task is to isolate the pixels that are eligible to change to urban land cover. All pixels that are already assigned an urban land cover are set null based on a conditional statement. What is left is arbitrarily reclassified to a value of 100 . The map of 100 value pixels is then added to the graded weights map described in chapter two. The main assumption of the graded weights map is that the higher grade the more likely it will change to urban in the future. In this analysis, we assume the highest rated pixels are most suited to high urban development. The required number of new high development pixels is calculated. The highest graded pixels are again reclassified to 100 again. The next highest grade is reclassified and then the next weight grade is reclassified and so on until the number of pixels in a weight grade exceeds the remaining required pixels that need to be converted. The pixels in that weight grade are reclassified to one, and all else are set to a null value. Those set to one are then converted to points with the raster to point conversion tool. Then the select random points tools is used to randomly select the number of pixels that still need to convert to high development. The selected points are then converted pack to pixels and reclassified to 100 . Now there are two raster datasets of the study area where values are either 100 which represent new high urban growth or have pixels set to null. 
The cell statistics tool set to the sum function is used to combine the two since it ignores the null values unlike raster calculator. This combined raster goes through conditional statement in raster calculator that sets the null value to zero. It is now prepared for addition back to the original NLCD LULC dataset. Any land category with a value over 100 must be new high development. A final reclassification of these values to the high urban land cover category value completes an iteration of the model. This geoprocessing routine is then repeated for medium development, then low development, and finally open development. The final future land cover product is complete at this point.

The development of the routine took place in the ModelBuilder feature in ArcGIS. It is essentially a graphical programming interface. It allows for any ArcGIS data processing tool to be linked to other tools to form a more complex tool tailored to a specific task. The complexity of this tool made full automation in the ModelBuilder environment difficult to accomplish. Several logical issues were could not be addressed within its structure. ArcGIS functions can also be written as code in the Python scripting language. Python allows for solving the problem of finding which weight grade will need to have new urban growth pixels randomly assigned from it programmatically. In the event of a new model parameterization, a script allows for the rapid production of the future land cover product. In ModelBuilder, several parameters would have to be adjusted manually add to the time of running the model.

With the release of ArcGIS 10.1, the Python toolbox feature was added. This allows for a custom ArcGIS geoprocessing toolbox to be developed directly from a Python script template. The model can now be wrapped into its own easily transferable 
tool increasing efficiency. The full Python toolbox script is presented in section two of this appendix. Code comments are interspersed throughout to facilitate reading the script.

\section{A.2 Python Toolbox Script}

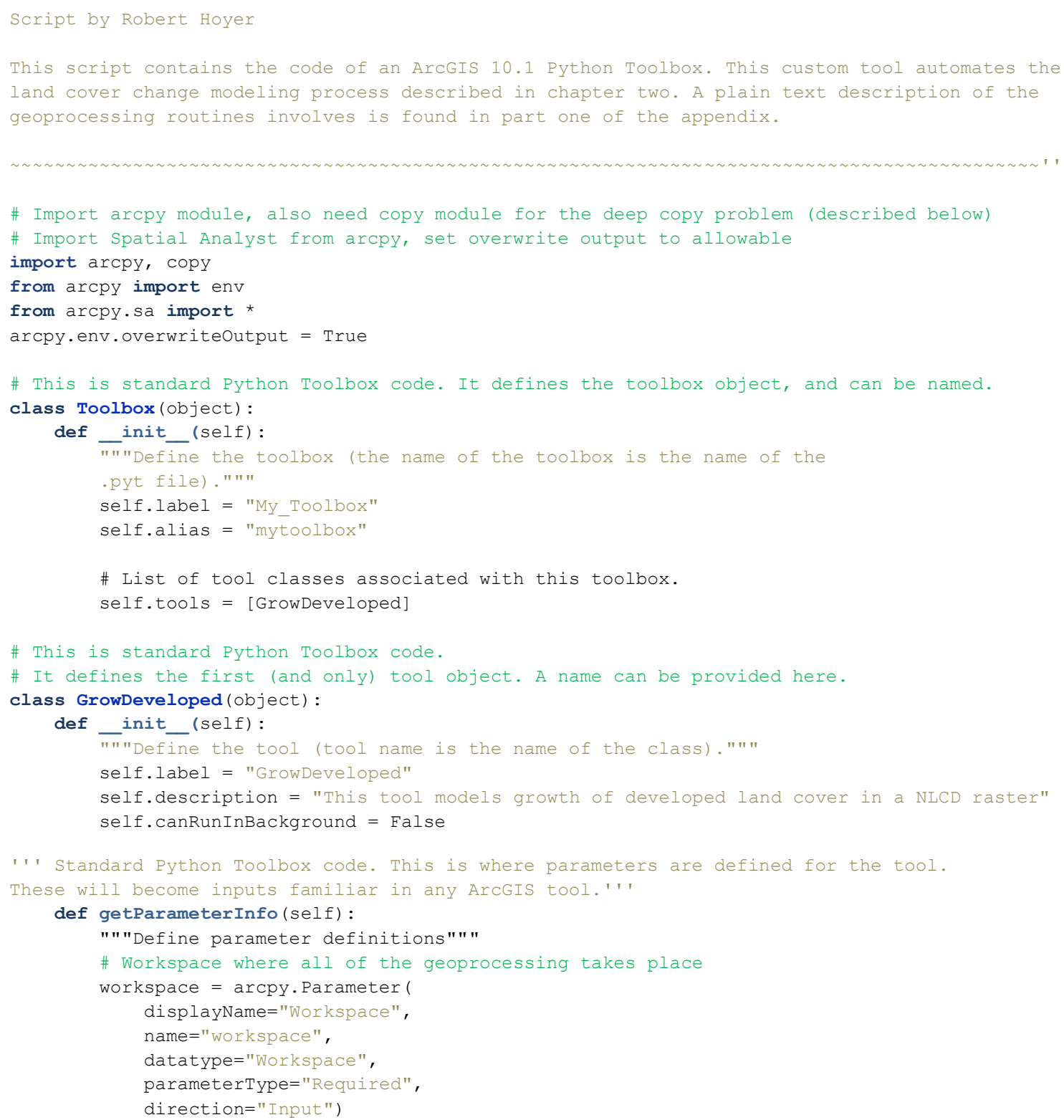




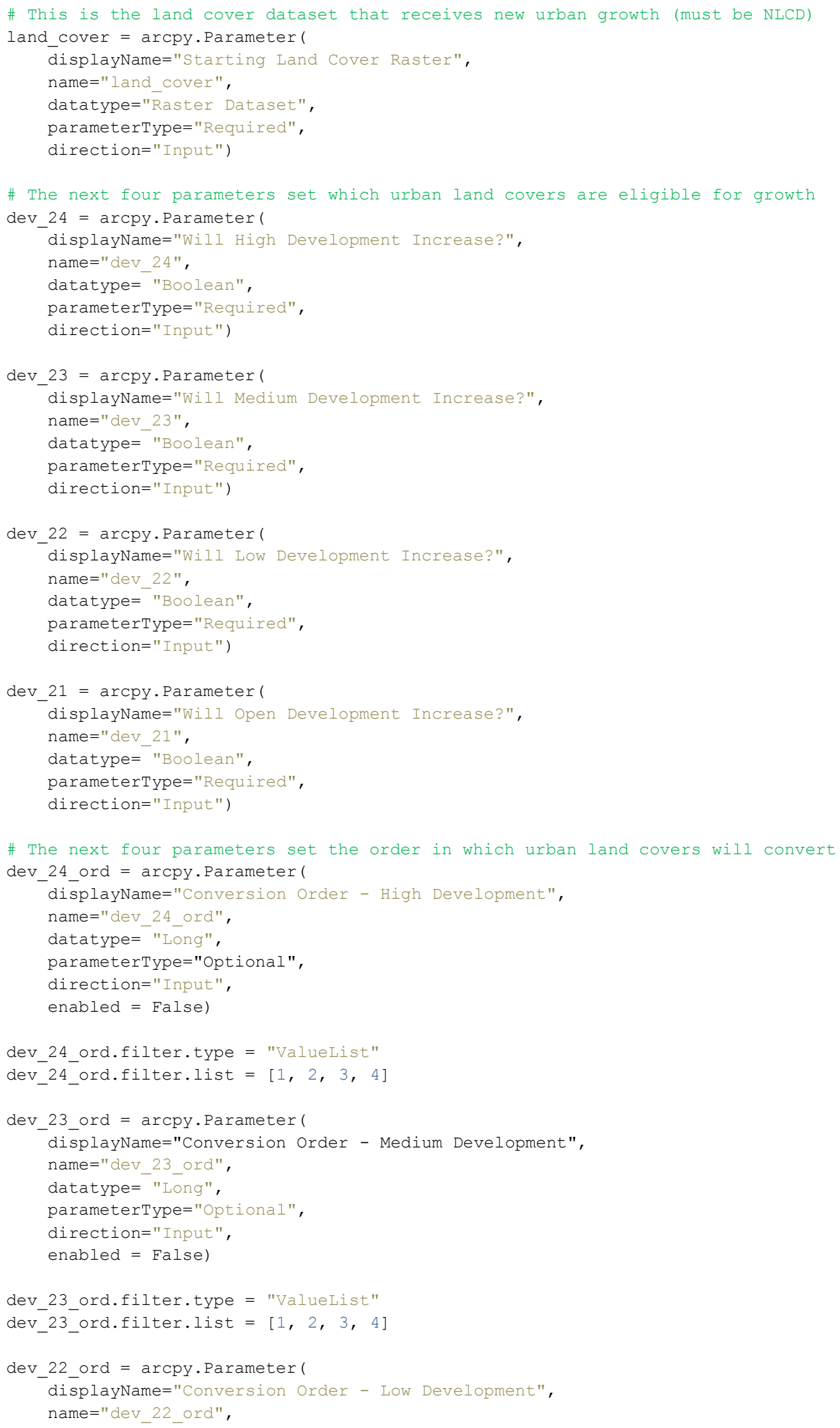




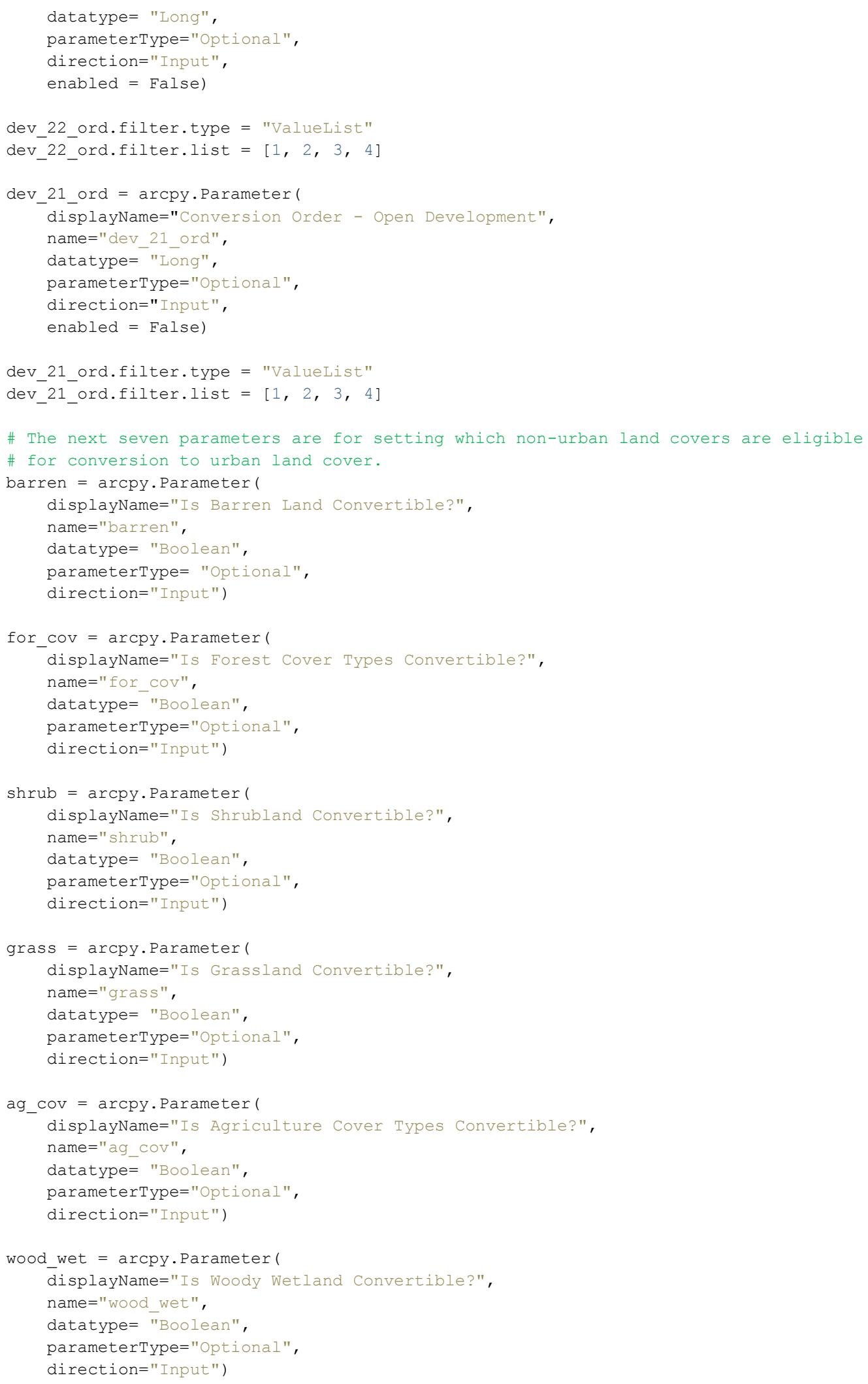




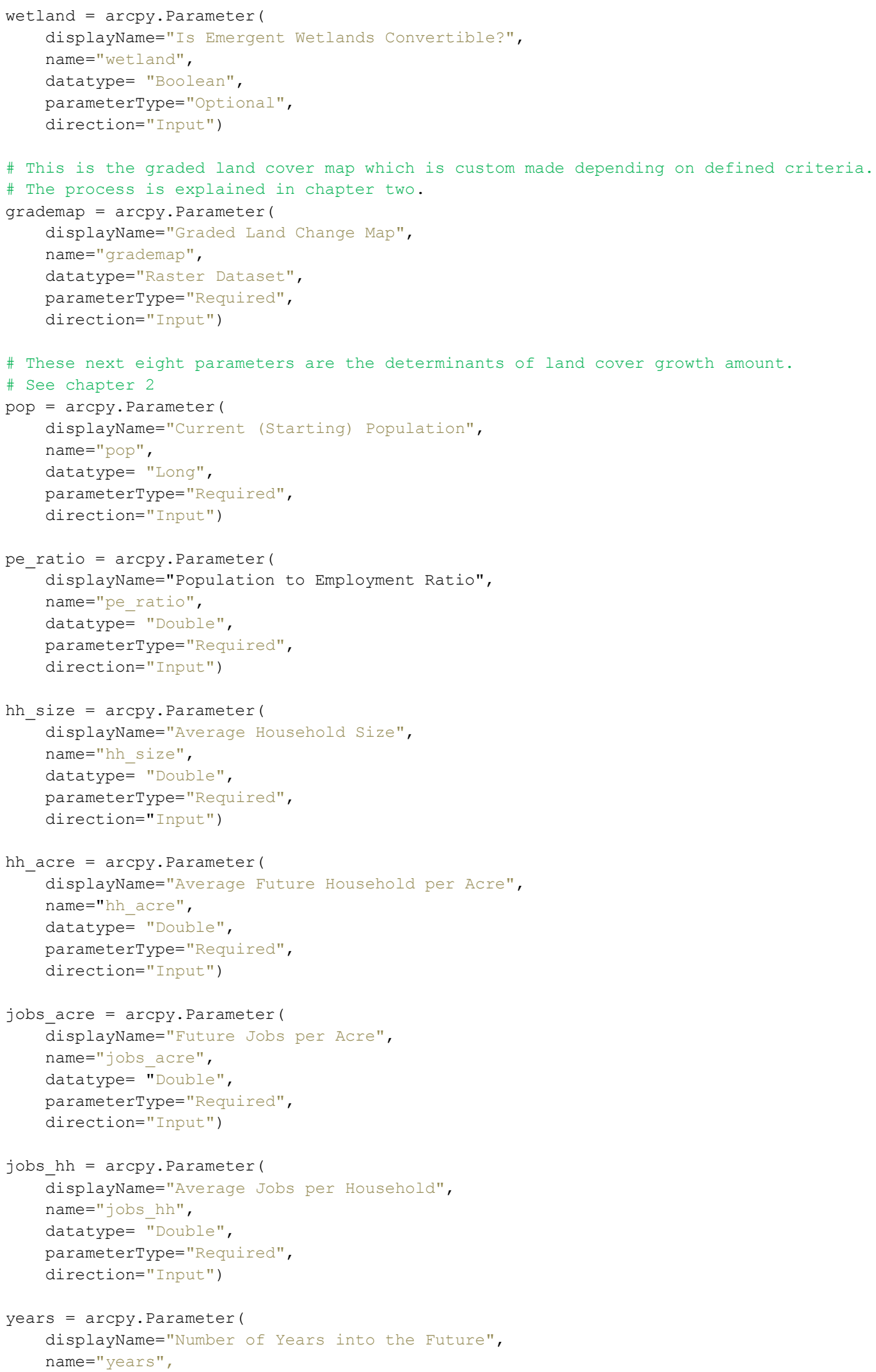




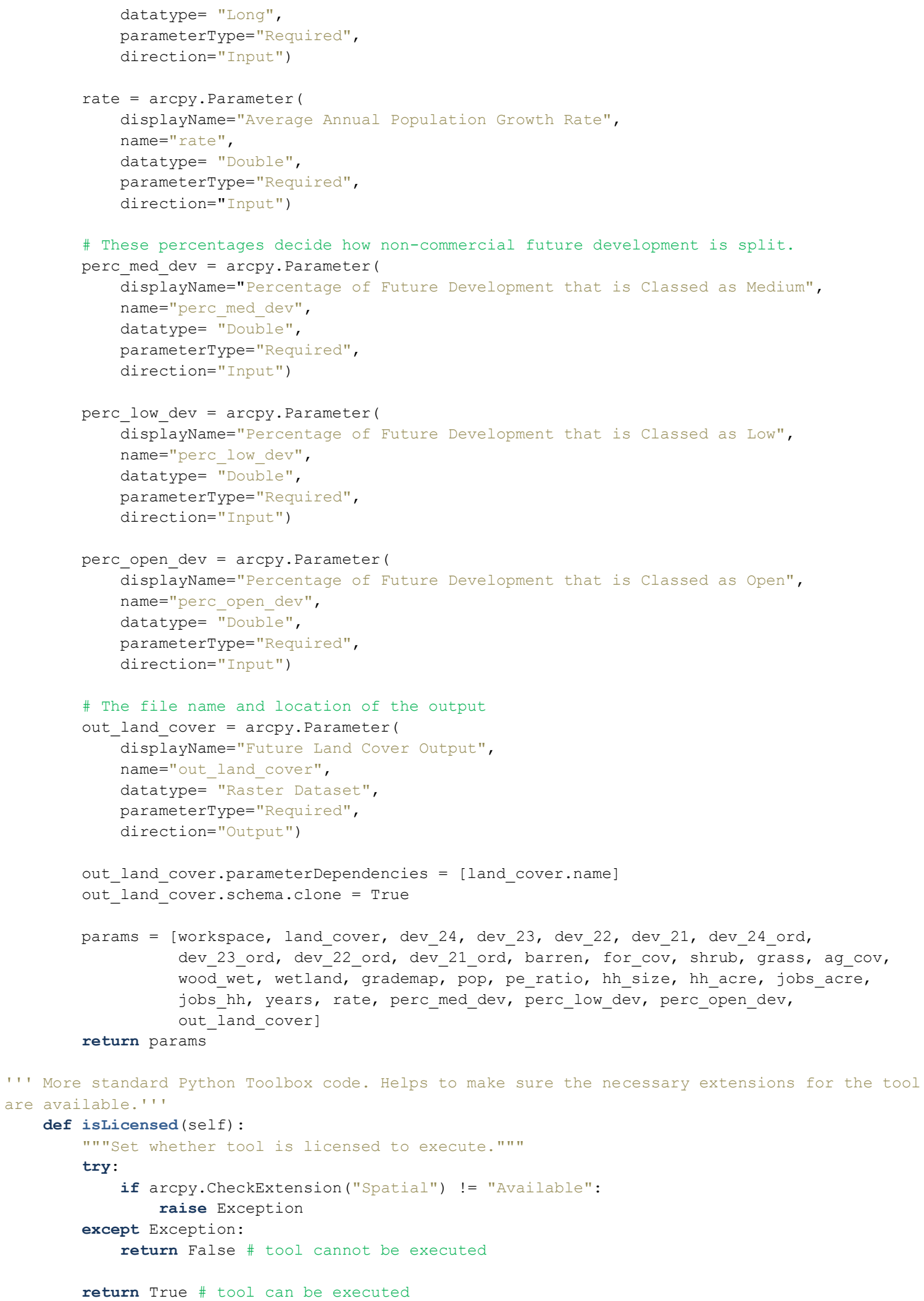




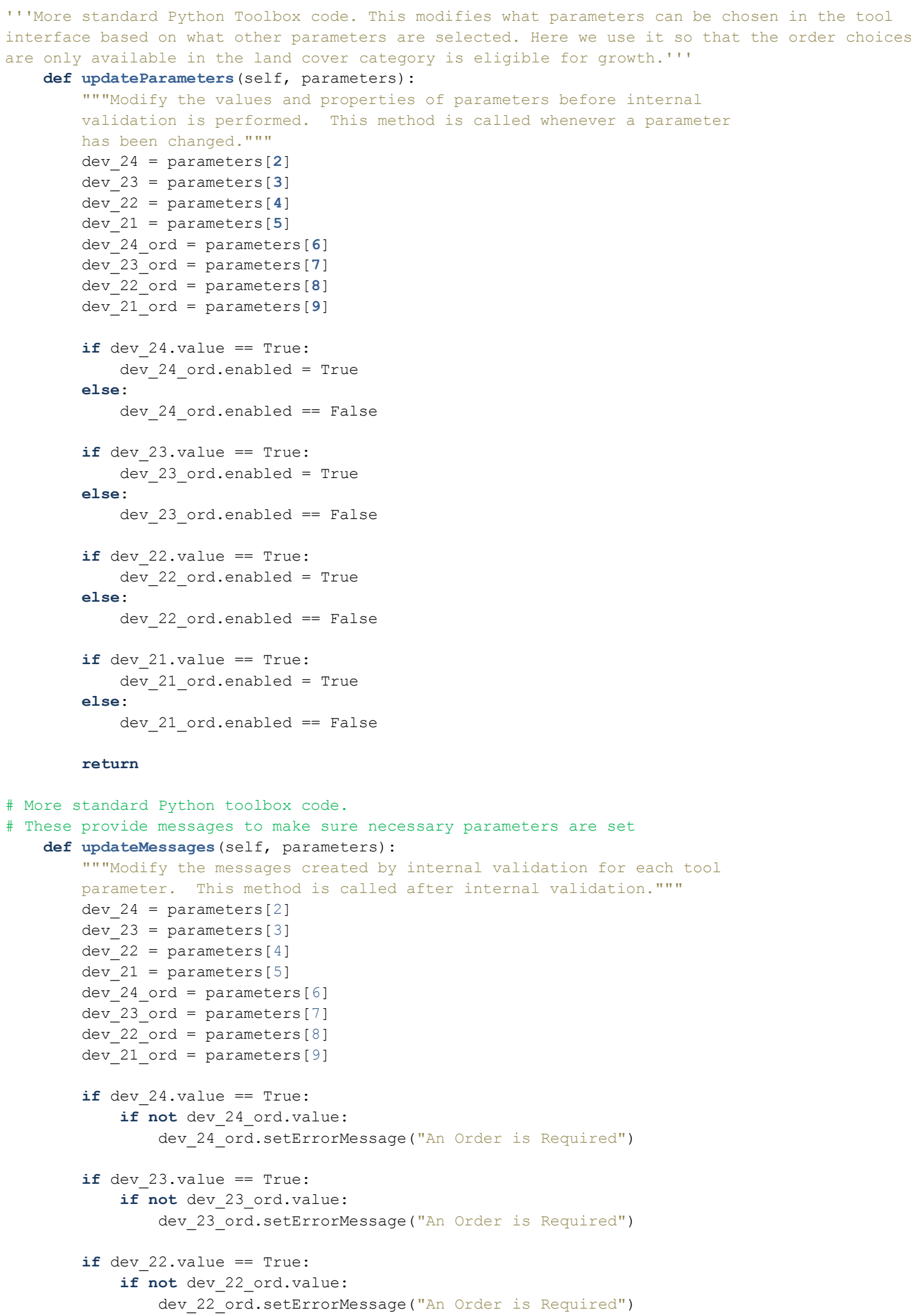


if dev_21.value $==$ True:

if not dev_21_ord.value:

dev_21_ord.setErrorMessage ("An Order is Required")

\section{return}

\# The actual script that does the geoprocessing

def execute(self, parameters, messages):

"""The source code of the tool.""

''' I needed to set the parameters from the input from the above ParamterInfo function. Since all of them are text, they needed to be cast as their actual data type for the tool to work' ' '

workspace $=$ parameters [0].valueAsText

land_cover $=$ parameters [1].valueAsText

dev 24 = bool (parameters [2]. valueAsText)

dev $23=$ bool (parameters [3]. valueAsText)

dev_22 = bool (parameters[4].valueAsText)

dev 21 = bool (parameters [5]. valueAsText)

dev_24_ord $=$ int (parameters [6].valueAsText)

dev 23 ord = int (parameters [7].valueAsText)

dev_22_ord $=$ int (parameters [8].valueAsText)

dev_21_ord $=$ int (parameters [9].valueAsText)

barren = bool (parameters [10]. valueAsText)

for_cov = bool (parameters[11].valueAsText)

shrub = bool (parameters [12].valueAsText)

grass = bool (parameters[13].valueAsText)

ag_cov $=$ bool (parameters [14].valueAsText)

wood_wet $=$ bool (parameters [15]. valueAsText)

wetland = bool (parameters [16].valueAsText)

grademap $=$ parameters [17]. valueAsText

pop $=$ int (parameters [18]. valueAsText)

pe_ratio $=$ float (parameters [19].valueAsText)

hh_size = float (parameters[20].valueAsText)

hh acre $=$ float (parameters [21].valueAsText)

jobs_acre = float (parameters[22].valueAsText)

jobs hh = float (parameters[23].valueAsText)

years $=$ int (parameters [24].valueAsText)

rate $=$ float (parameters [25].valueAsText)

perc_med_dev $=$ float (parameters [26].valueAsText)

perc_low_dev $=$ float (parameters [27].valueAsText)

perc open dev = float (parameters [28].valueAsText)

out_land_cover $=$ parameters [29].valueAsText

arcpy.env.extent $=$ land_cover

\# Reclass value list gets filled in with below code

recl_val_list $=[$ None $] * 4$

if dev_24 == True:

recl val list [dev 24 ord - 1] $=24$

if dev_2 $\overline{3}==$ True:

recl val list $[\mathrm{dev} 23$ ord -1$]=23$

if dev_2 $\overline{2}==$ True:

recl_val_list [dev_22_ord - 1] $=22$

if dev $2 \overline{1}==$ True:

recl_val_list [dev_21_ord - 1] $=21$

\# List of land covers that can change, filled in with code below

change_list $=[]$

if barren $==$ True:

change_list.append (31) 


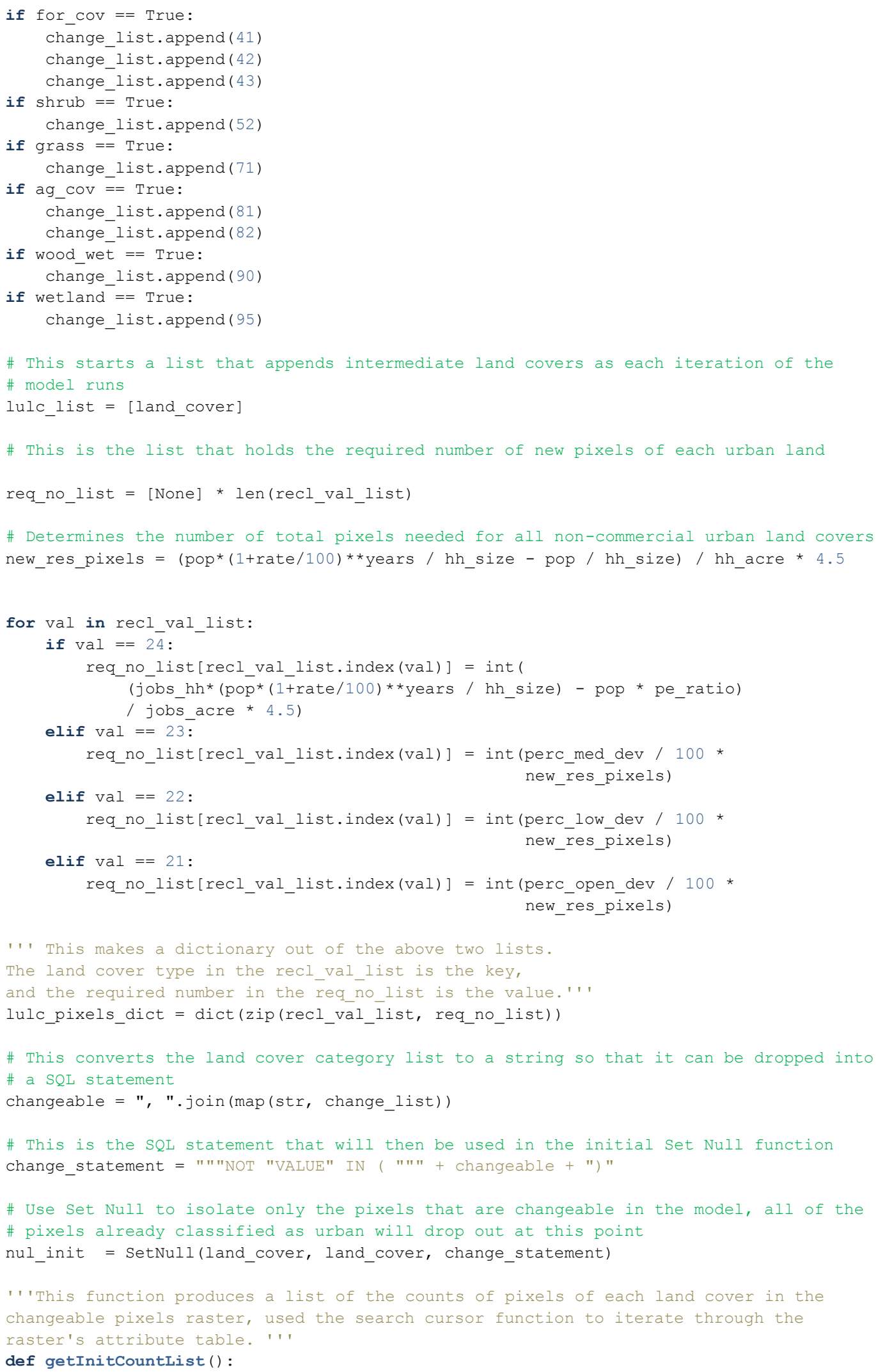




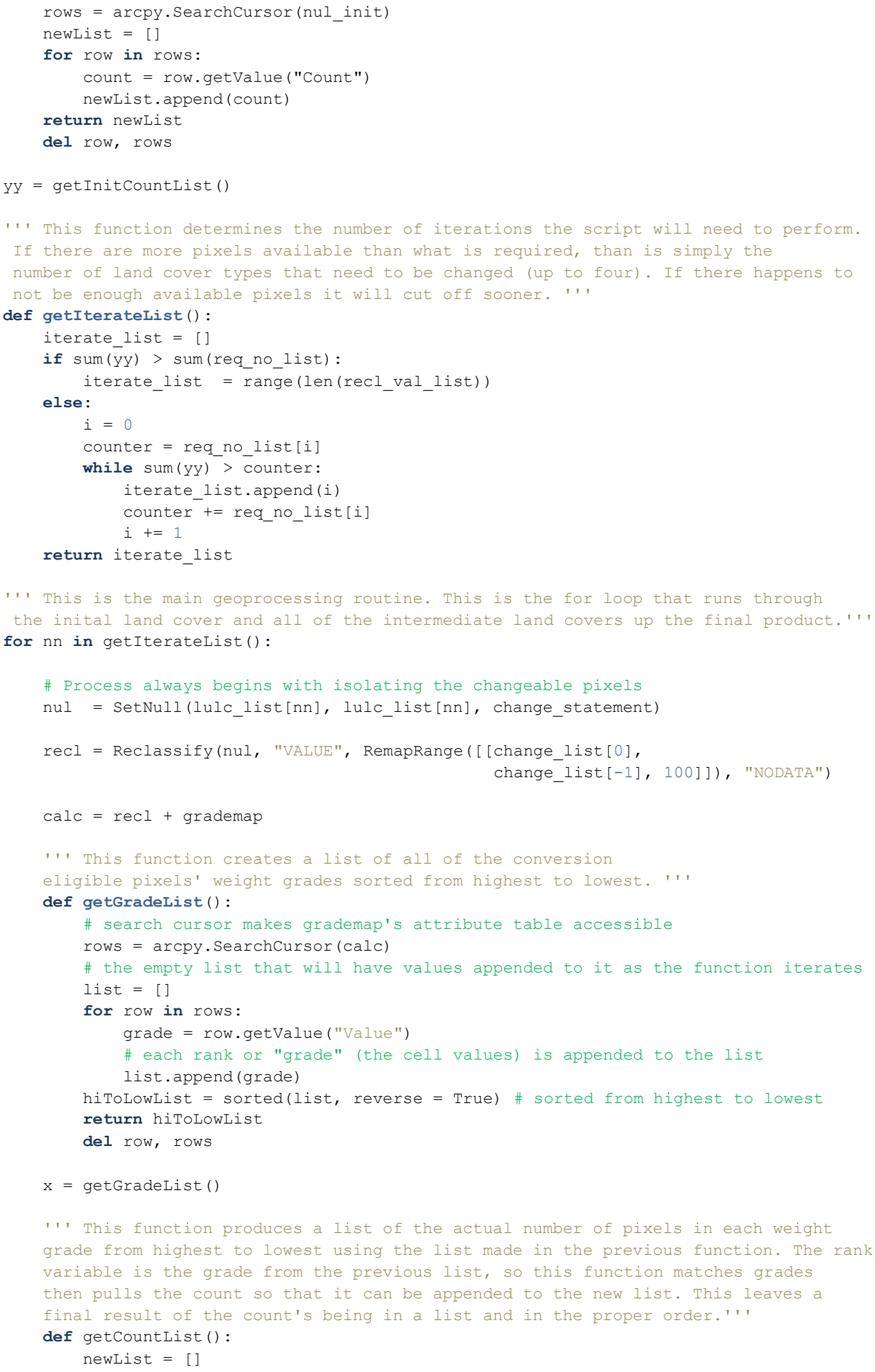




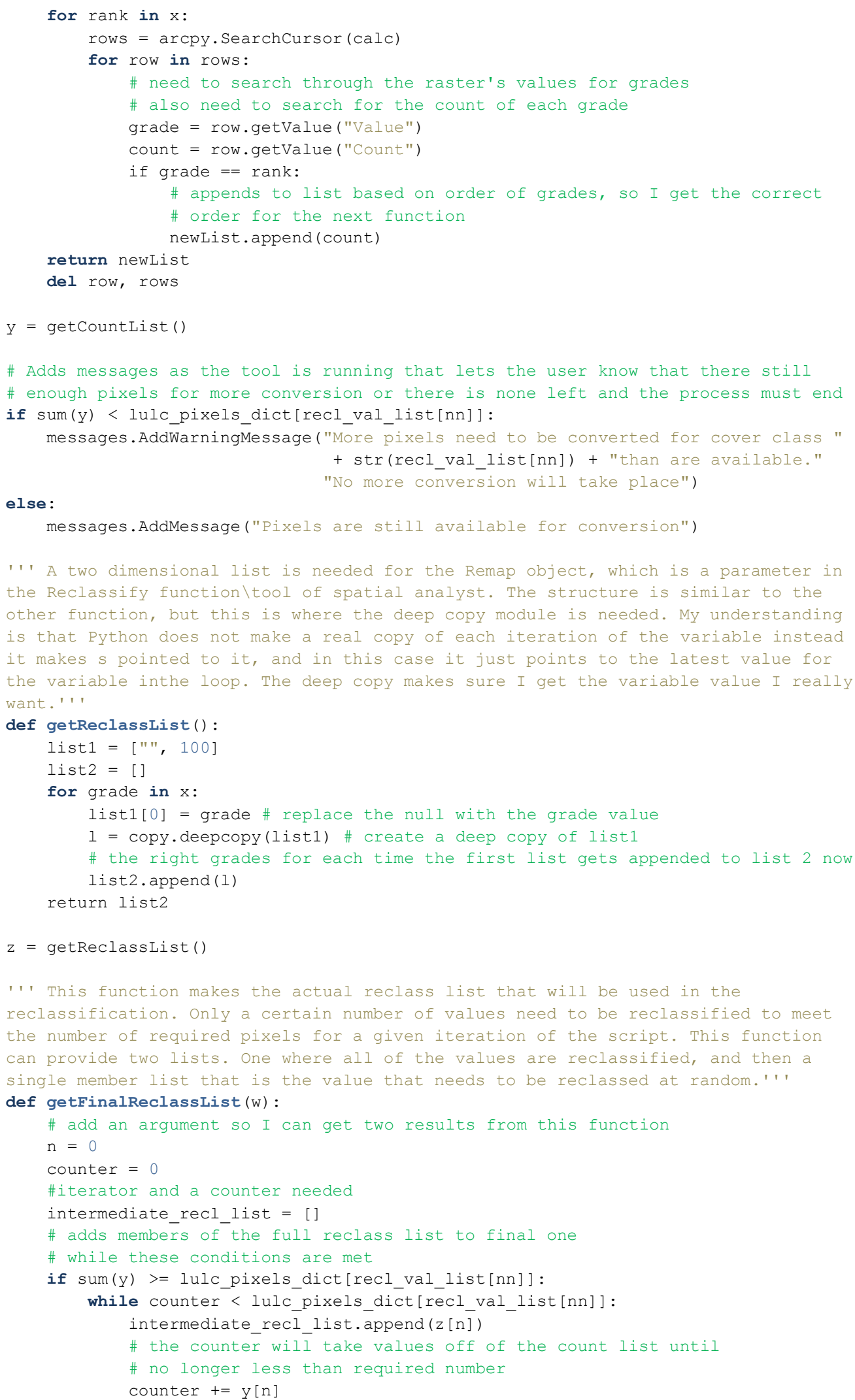




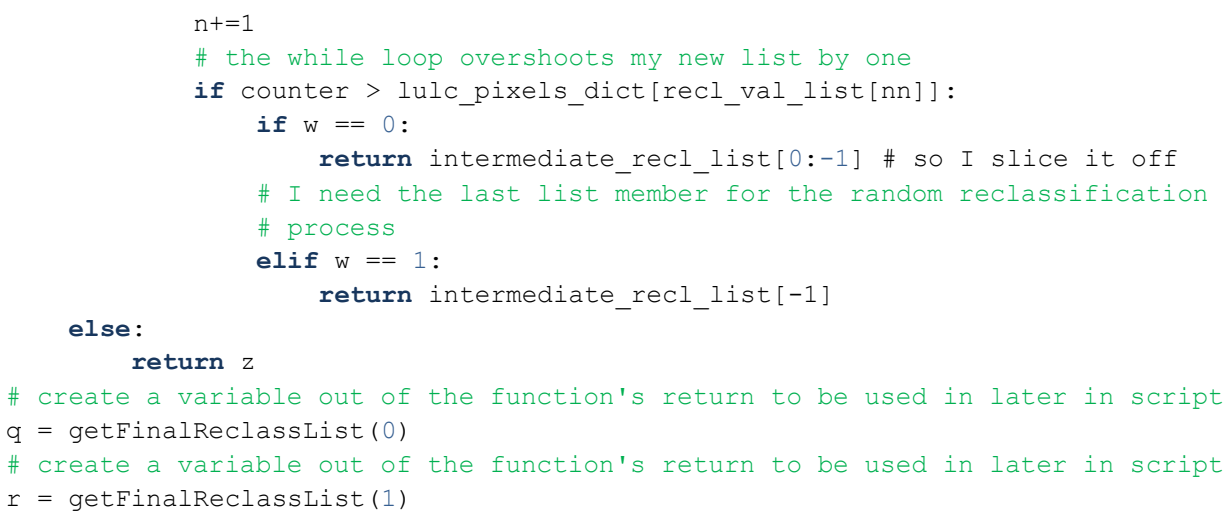




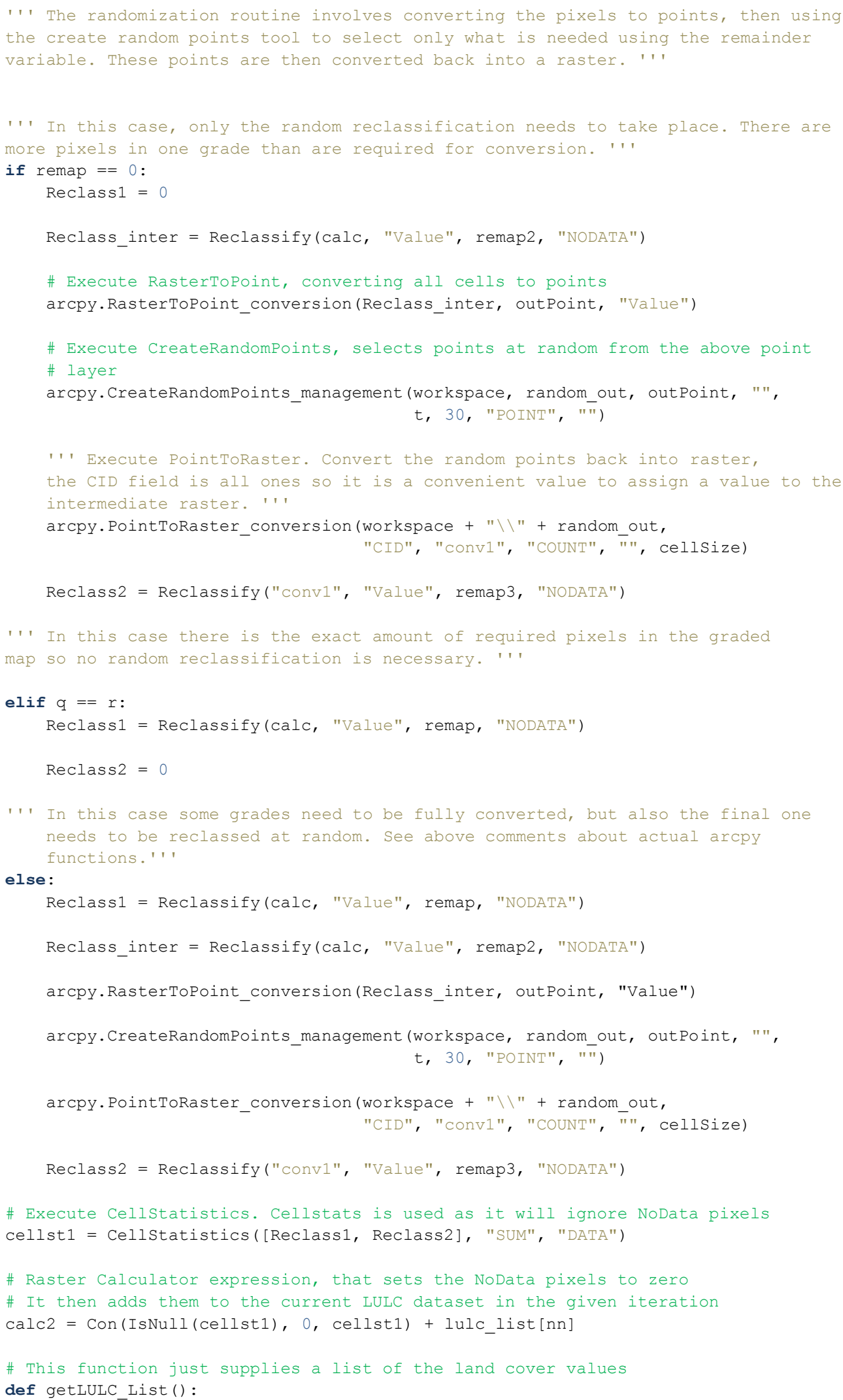




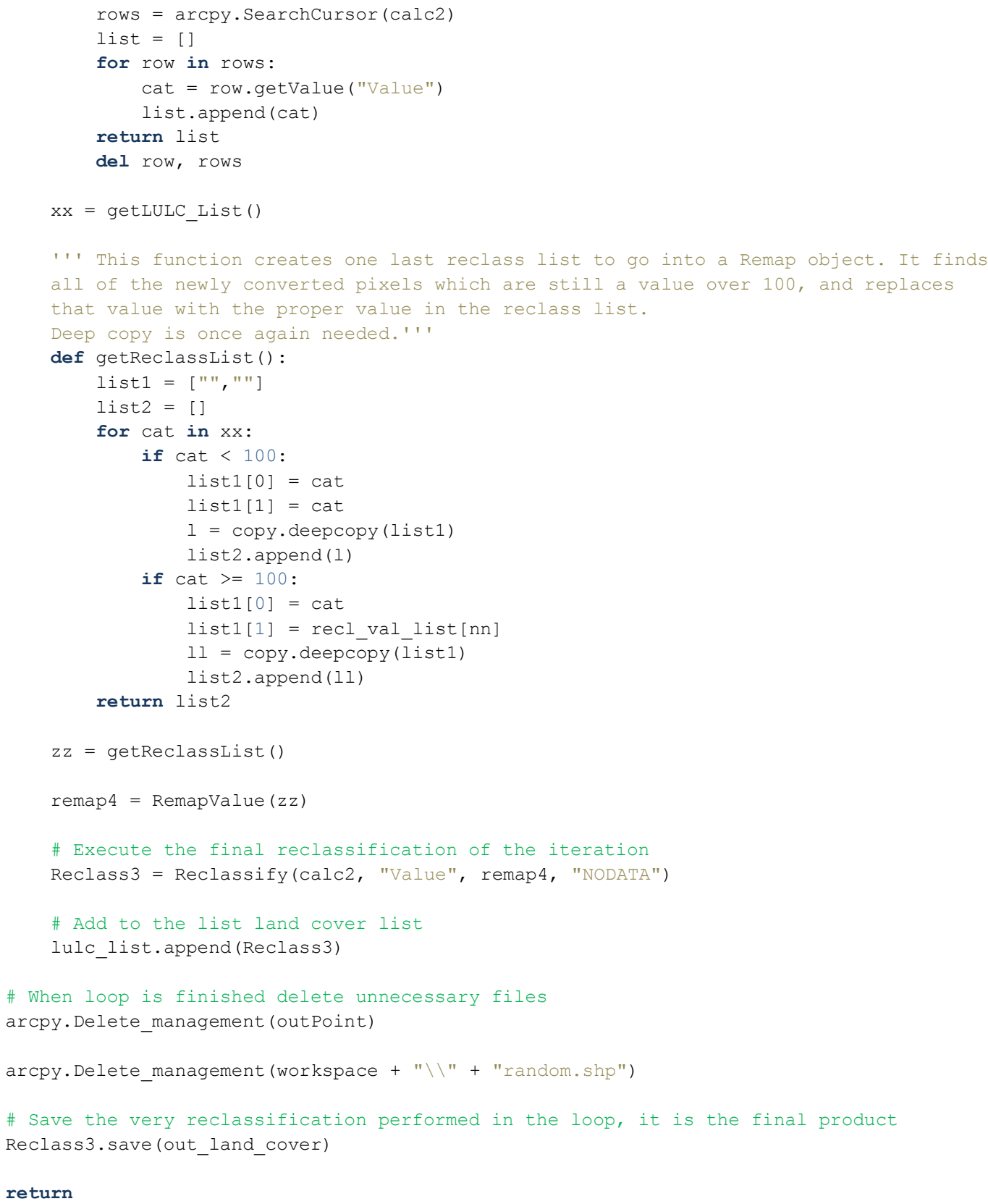

return 
Appendix B: Chapter III Supplementary, Additional Methods, Results, and Model Information

\section{B.1 Supplementary Methods}

\section{Empirical Data and Stream Export Load Estimation}

For this study the historical time period was the calendar years 1981 to 2010. In

the Tualatin four gauges were identified as having suitably long runoff records to perform a water yield calibration two of which spanned the entire thirty year study period. The Yamhill basin did not have any gauge that spanned all thirty years, but had four gauges that had at least ten years of continuous data to calculate a decadal average (Table B.1). The average daily flow in cubic feet per second (cfs) was obtained from the USGS National Water Information System (2013) or from the Oregon Department of Water Resources (OWRD, 2013). This was then converted to annual yield in millimeters using each sub-watersheds estimated area to allow for direct comparison with InVEST outputs.

Streamflow data is also critical for developing load estimates for the three water quality constituents modeled. Observations in the form of a discrete grab samples $(\mathrm{mg} / \mathrm{L})$ were obtained from the local wastewater/stormwater management agency Clean Water Services (CWS), the USGS National Water Information System (NWIS), and Oregon Department of Environmental Quality (DEQ). Observations were retained that spatially and temporally corresponded to a streamflow gauge. Time periods and number of observations varied among the sampling stations with Yamhill basin not having as rich a database. Only a single sampling station in the basin had a record large enough to develop a load estimate, but had no corresponding flow record. Simulated flow data from 
the semi-distributed process based model Soil and Water Assessment Tool (SWAT) (Arnold et al., 2012) was used in lieu of empirical data for load estimation. In total four locations, three in the Tualatin (Figure B.1) along with the location in Yamhill had water quality constituent loads estimated for InVEST calibration.

Table B.1

Summary of flow gauges/ water quality sampling stations and the time periods for each used in the calibration process of InVEST freshwater models.

\begin{tabular}{|c|c|c|}
\hline USGS ID \# and/or Name & InVEST Model & Time Periods Modeled \\
\hline $\begin{array}{l}14207500 \text { Tualatin River at West } \\
\text { Linn, OR }\end{array}$ & $\begin{array}{l}\text { Water Yield, } \\
\text { Water Purification, Sediment } \\
\text { Retention }\end{array}$ & $\begin{array}{l}1981-2010,1981-1990,1991- \\
2000,2001-2010\end{array}$ \\
\hline $\begin{array}{l}14203500 \text { Tualatin River at Dilley, } \\
\text { OR }\end{array}$ & $\begin{array}{l}\text { Water Yield, } \\
\text { Water Purification, Sediment } \\
\text { Retention }\end{array}$ & $\begin{array}{l}1981-2010,1981-1990,1991- \\
2000,2001-2010\end{array}$ \\
\hline $\begin{array}{l}14206950 \text { Fanno Creek at Durham, } \\
\text { OR }\end{array}$ & $\begin{array}{l}\text { Water Yield, } \\
\text { Water Purification, Sediment } \\
\text { Retention }\end{array}$ & $2001-2010$ \\
\hline $\begin{array}{l}14202980 \text { Scoggins Creek below } \\
\text { Hagg Lake near Gaston, OR }\end{array}$ & Water Yield & $1981-1990,1991-2000$ \\
\hline $\begin{array}{l}14194150 \text { South Yamhill River at } \\
\text { McMinnville, OR }\end{array}$ & Water Yield & $2001-2010$ \\
\hline $\begin{array}{l}14192500 \text { South Yamhill River near } \\
\text { Willimina, OR }\end{array}$ & Water Yield & $1981-1990$ \\
\hline $\begin{array}{l}14193000 \text { Willimina Creek near } \\
\text { Willimina, OR }\end{array}$ & Water Yield & $1981-1990$ \\
\hline $\begin{array}{l}14196001 \text { Haskins Creek below } \\
\text { Reservoir plus Diversion to } \\
\text { McMinnville, OR }\end{array}$ & Water Yield & $1981-1990,1991-2000$ \\
\hline $\begin{array}{l}\text { Oregon DEQ Water Quality } \\
\text { Monitoring Station }\end{array}$ & $\begin{array}{l}\text { Water Purification, Sediment } \\
\text { Retention }\end{array}$ & $1996-2010$ \\
\hline
\end{tabular}



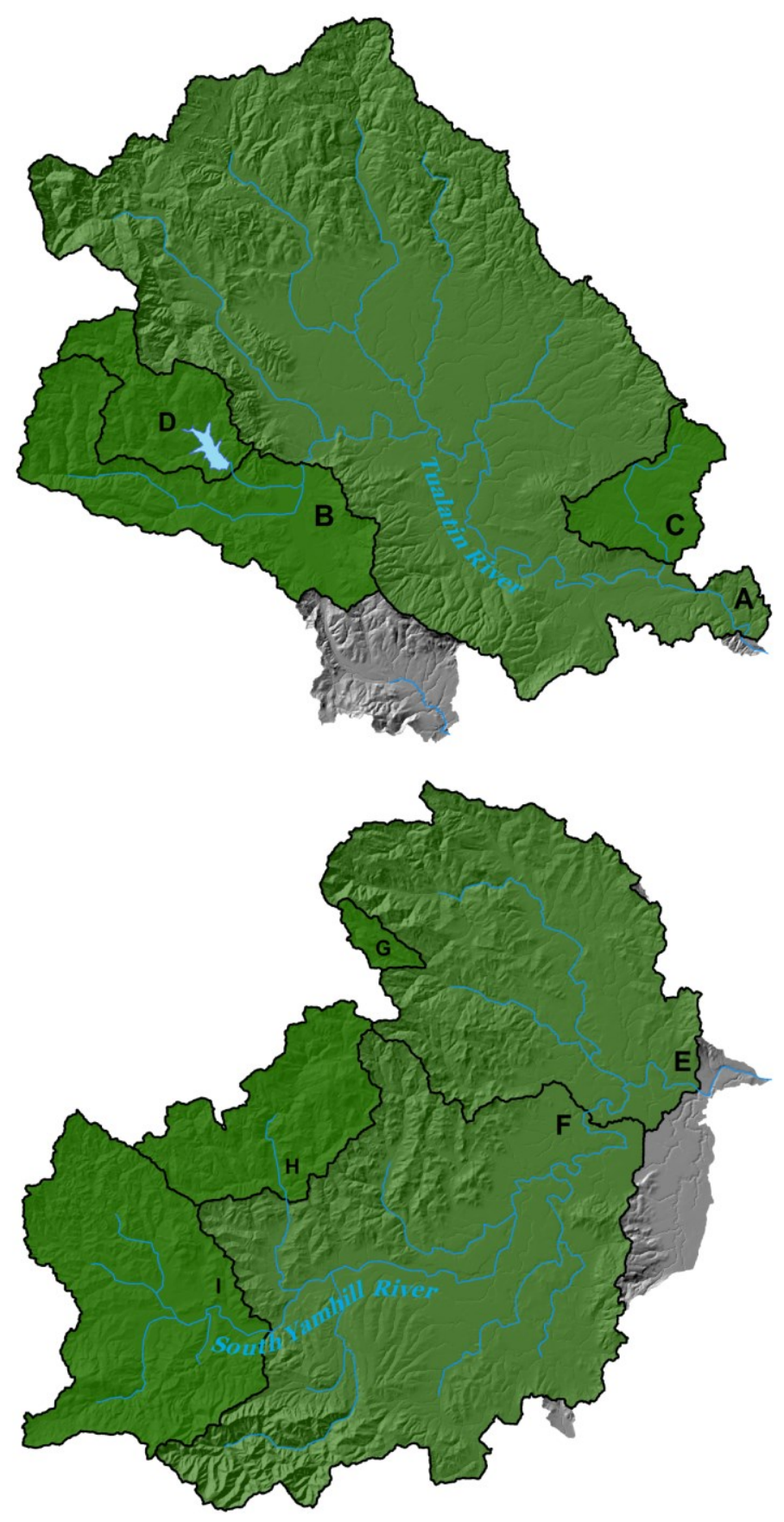

Figure B.1

Gauged sub-watersheds used in the calibration of InVEST.

A) 14207500 - Tualatin R. at West Linn, B) 14203500 - Tulatin R. at Dilley,

C) 14206950 - Fanno Cr. at Durham, D) 14202980 - Scoggins Cr. Below Hagg Lake,

E) Oregon DEQ Monitoring Station, F) 14194150 - S. Yamhill R. at McMinnville,

G) 14196001 - Haskins Cr. below reservoir plus diversion to McMinneville,

H) 14193000 - Willimina Cr. near Willimina, I) 14192500 - S. Yamhill R. near Willimina 
Stream loadings for each water quality constituent of interest was estimated using the USGS estimator program LOADEST (Runkel, Crawford, and Cohn, 2004).

LOADEST uses empirical streamflow and constituent concentration data to develop a regression model using the adjusted maximum likelihood method. LOADEST's default model includes the linear and quadratic term of streamflow and several terms based on decimal time to account for seasonal and trend effects. The regression equation:

$$
\ln L=\beta_{0}+\beta_{1} \ln Q+\beta_{2} \ln Q^{2}+\beta_{3} \sin (2 \pi \text { dtime })+\beta_{4} \cos (2 \pi \text { dtime })+\beta_{5} \text { dtime }+\beta_{6} \text { dtime }{ }^{2}
$$

where $L$ is load, $Q$ is streamflow, and dtime is decimal time. LOADEST employed data centering on predictor variables to minimize multicollinearity issues introduced by using terms based on the same original data. Decimal time was data of sample assumed at noon for each observation. Depending on the Akaike Information Criterion (AIC), a version of the above model using all or a subset of the predictor variables was used for a given constituent at a given sampling station. The model estimates a daily load for a selected range of dates. Extrapolation of some of the models was required to estimate loads outside the calibration date range as well as for flows exceeding those in the calibration dataset. As the output must be highly aggregated to compare with InVEST outputs, we assume the results are reasonable. The daily load estimates were summed to the annual time-step and then averaged over at least a decade depending on each gauge/sampling station's record length. These annual averages were then used to compare and adjust parameters in the InVEST water quality models.

Since InVEST's purpose is to estimate the effect of land cover/ land use on nutrient retention, point sources should be accounted for and subtracted out of a final 
loading estimate prior to calibration. In the study area the main point source loading come from wastewater treatment plant effluent. Data was acquired from CWS and the McMinnville treatment plant. Large gaps occurred in data and record length and number of observation varied by plant. Rough loading estimates for total nitrogen and total phosphorus were calculated using a decadal average of constituent concentration and effluent volume. These estimates were then subtracted from the load estimates developed in LOADEST for the gauge/ sampling stations downstream of the plants. Data is lacking for point sources during the majority of the 1980s. An average from the following decades was used to conservatively account for point sources from wastewater treatment plants.

\section{Spatial Data}

A limitation of National Land Cover Dataset (NLCD) is a lack of comparable datasets for earlier points during the study period. The 2001 product is very similar for our study area. NLCD 1992 has many key differences to later versions including classification scheme that make direct comparison difficult. For these reasons NLCD 2006 was used as an input for the entire study period. To simulate the potential of streams in the study area receiving a new management regime and/or restoration effort, a thirty meter buffer width was overlaid over the national hydrography dataset stream layer for all streams in the study area. All land cover falling within this buffer is converted to a natural vegetation land cover category available in NLCD. This yields a riparian buffer of fifteen meters on each side of the stream's center line. The resolution of the NLCD is 30 
meter pixels making this the minimum possible buffer size. It is assumed that larger buffers are not likely given the current policy framework.

A visual inspection of the most current NLCD product from 2006 depicts riparian corridor vegetation in low sloping (less than 5\%) and bottomland areas as woody wetland land cover type. Given that NLCD's origin is remotely sensed LANDSAT TM data, this is likely due to soil moisture characteristics more than vegetation type for these areas. In steeper upland areas (greater than 5\%), adjacent natural land cover falls into one of the three forest types available in NLCD. In reality both land cover types will have similarities in vegetation composition but may have differences in soil characteristics that warrant distinction. Assuming that forest stream's will have a deciduous component of alder and maple as well as Douglas Fir, Western Red Cedar, and other native conifers, a land cover category of mixed forest was overlaid on buffers in these areas. Distinguishing these two land cover types will make a difference in the final InVEST modeling effort as it is assumed that woody wetland vegetation at lower slopes will have a higher capacity to capture sediments and nutrients.

Climate datasets obtained from the University of Idaho's Gridded Surface Meteorological Data (METDATA) program required additional processing for use with InVEST. At four kilometers, it provides a high degree of spatial resolution important for the topographically variable study area. At a daily time-step, it is too fine for direct use in InVEST. For the calibration step, aggregation to the annual scale was performed and then averaged over the same time period that empirical data was available for each runoff gauge/sampling station. Minimum and maximum temperature along with shortwave 
downwelling flux (incoming radiation) was used to calculate a reference evapotranspiration $\left(\mathrm{ET}_{0}\right)$ which is interchangeable with PET. The Hargreaves method was selected to keep inputs comparable with other project modeling efforts and performed in the R package SPEI ver. 1.3 (Baguería and Vicente-Serrano, 2013, R Core Team, 2013). SPEI outputs monthly $\mathrm{ET}_{0}$ which was further aggregated to the annual average.

\section{Land Cover Modification}

The Dilley gauge making up approximately $1 / 6$ the size of the Tualatin accounts for $1 / 5$ to almost $1 / 3$ of the total nitrogen or total phosphorus load at the West Linn gauge once point sources are taken into account. This includes Scoggins creek which is dammed to form Hagg Lake, and does not contribute large nutrient loads. We hypothesized that Wapato Creek was contributing a disproportionate amount of nutrients in the basin. Wapato lake was drained in the 1930s so its bed could be actively farmed (Wapato Lake Water Quality Management Plan, 2009). A dike breached there in 2007 and when flood waters were pumped out to the river drainage, they caused downstream water quality problems in the Tualatin main stem. Also a small amount of concentration samples from Wapato creek suggest it contributes much more nutrients than the rest of the system that drains to the Dilley gauge (NWIS, 2013). For these reasons, we reclassified the area making up Wapato Lake in the input LULC raster to allow for higher nutrient export coefficient assignment. The sediment load is disproportionate at the Dilley gauge compared to the entire Tualatin basin also. Unlike with nutrients, we could not make the theoretical link to strictly Wapato Lake. Instead the entire upper Tualatin and Wapato 
Creek basins were reclassified in the land cover raster to facilitate a different parameterization. Scoggins Creek was excluded as Scoggins Dam traps almost all sediments from the rest of the system.

B.2 Supplementary Results

Empirical Stream Load Estimates

Adjusted maximum likelihood regression models in LOADEST show that stream loadings have a relationship with flow, and in almost all cases they display seasonal and trend effects as well. The fit for sampling station varies but shows a pattern of total nitrogen having the highest fit, followed by total phosphorus, with total suspended sediments being the poorest (Table 3.3). Nash-Sutcliffe efficiency coefficients reveal that models are typically better than the empirical mean. In the case of sediments however there is a relatively high bias. This was corrected by adjusting the outputs by the model's total percent bias. Considering InVEST produces final estimates at the annual average based on multiple years of data, this simple correction procedure is deemed reasonable.

The LOADEST results also reveal the variable processes affecting water quality occurring in the basin. There are negative trends taking place in the two sub-basins where full thirty year estimates were produced (Figure B.2). The monitoring station near the mouth of the Tualatin saw annual export estimate for total phosphorus averaged by decade drop by nearly $100 \%$ between the estimate for the 1980 s and 2000 s from 330170 $\mathrm{kg} /$ year to $167000 \mathrm{Kg} /$ year. The load estimates are highly related to flow (Figure B.3), but are not necessarily tightly coupled to each other especially when examining the early years of the study period. Changes in land use and management also played a role. We 
hypothesis this is why we observe negative time trends in most on LOADEST models especially with Total Phosphorus (Tables B.2 - B.5). We parameterized InVEST on the decade of $2001-2010$. More data is available and we assume it contains fewer legacy effects than the full study period. We then applied these values and increased them by a uniform rate to achieve the best calibration for the full thirty year study period as we assume the longer period captures more the natural variability in precipitation that will also occur in the future. Considering the nature of the data as well as lack of a point source record for much of the 1980s, this method was seen as viable compromise between the trends due to climate and those due to land use/management. An additional problem was lack of point source data in terms of wastewater treatment plant effluent for the 1980s. The two following decades were averaged which likely produces an underestimate. 

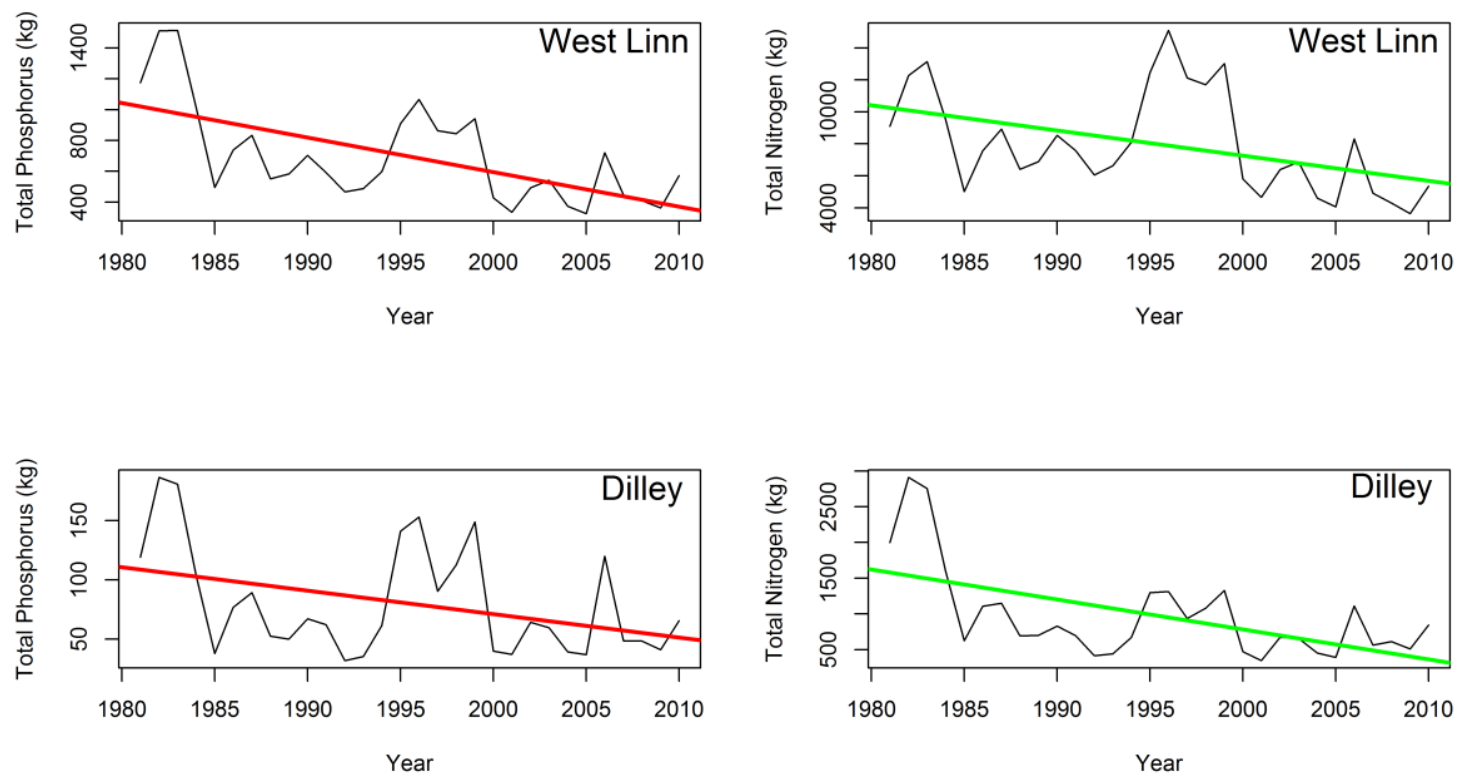

Figure B.2

Trends in stream loadings for total phosphorus and total nitrogen for two gauged subbasins in the Tualatin river basin. The graphs represent daily estimates produced using the estimator program LOADEST aggregated to the annual time scale. Trendlines are the linear function of stream loading to time. 


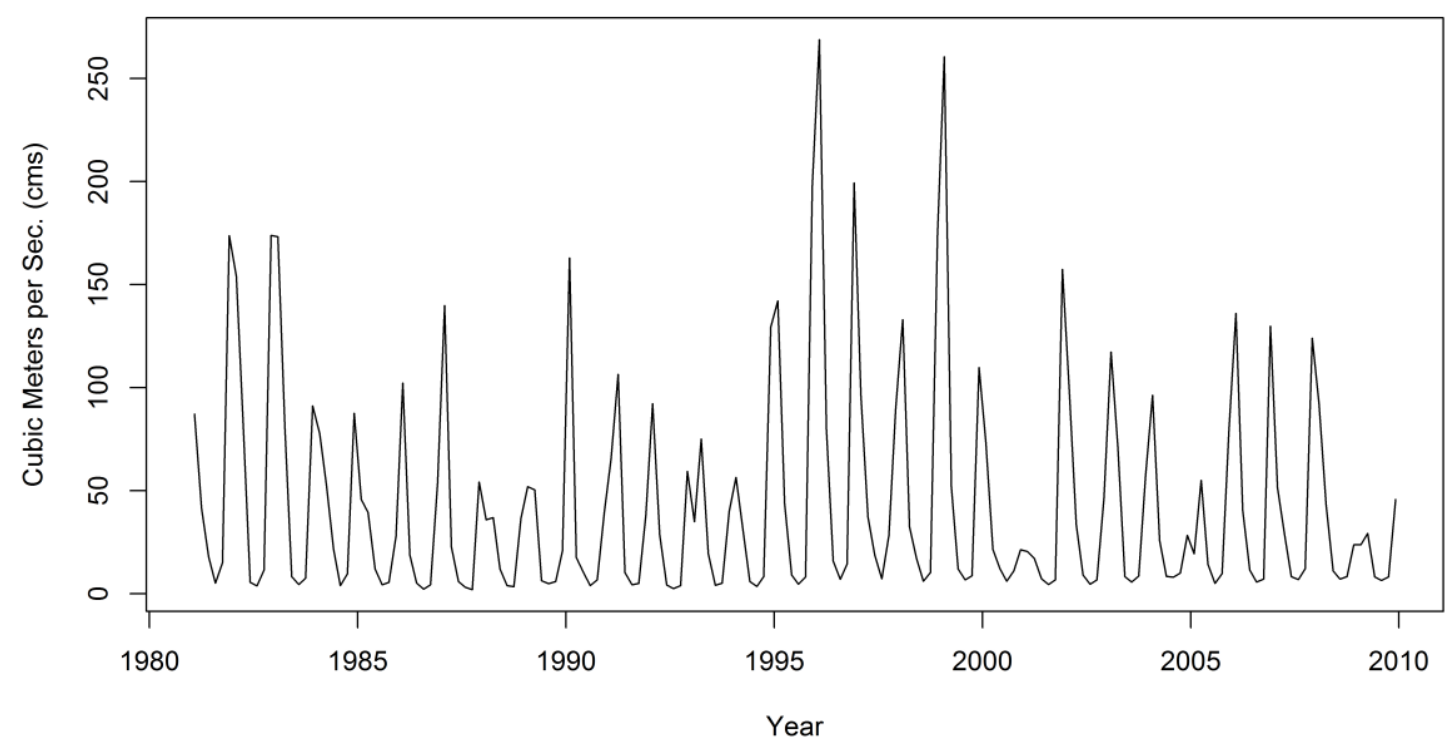

Figure B.3

Average daily flow (cms) by month for the study period.

Table B.2

Regression tables for adjusted maximum likelihood models predicting daily stream export loads for total nitrogen, total phosphorus, and total suspended sediments. Station location is Tualatin River at West Linn (USGS ID 14207500). Explanatory variables are forms of flow and decimal time.

Observations are centered to reduce error introduced by multicollinearity.

(for model diagnostics, see Table 3.2)

\begin{tabular}{lllllll}
\hline & \multicolumn{2}{l}{ Total Nitrogen } & \multicolumn{2}{l}{ Total Phosphorus } & \multicolumn{2}{l}{ Total Suspended Sediment } \\
\hline $\begin{array}{l}\text { Model } \\
\text { Coefficient }\end{array}$ & Value & Std. Dev. & Value & Std. Dev. & Value & Std. Dev. \\
\hline$a_{0}$ & $8.4342^{* * *}$ & 0.0229 & $5.6727^{* * *}$ & 0.0263 & $9.8926^{* * *}$ & 0.0270 \\
$a_{1}$ & $0.8497^{* * *}$ & 0.0173 & $0.9407^{* * *}$ & 0.0212 & $1.5609^{* * *}$ & 0.0230 \\
$a_{2}$ & 0.0086 & 0.0080 & $-0.0320^{* *}$ & 0.0102 & $0.1271^{* * *}$ & 0.0110 \\
$a_{3}$ & $0.1885^{* * *}$ & 0.0309 & $-0.4175^{* * *}$ & 0.0356 & $0.3230^{* * *}$ & 0.0347 \\
$a_{4}$ & $0.1341^{* * *}$ & 0.0160 & $-0.0502^{*}$ & 0.0218 & $0.3339^{* * *}$ & 0.0269 \\
$a_{5}$ & 0.0003 & 0.0017 & $-0.0332^{* * *}$ & 0.0016 & $-0.0395^{* * *}$ & 0.0023 \\
$a_{6}$ & $-0.0017^{* * *}$ & 0.0002 & $0.0006^{* * *}$ & 0.0001 & $-0.0033^{* * *}$ & 0.0004 \\
\hline
\end{tabular}

Base Model Form

$\ln ($ Load $)=a_{0}+a_{1} \ln Q+a_{2} \ln Q^{2}+a_{3} \sin (2 \pi$ dtime $)+a_{4} \cos (2 \pi$ dtime $)+a_{5}$ dtime $+a_{6}$ dtime ${ }^{2}$

${ }^{* * *} \mathrm{p}<0.001,{ }^{* *} \mathrm{p}<0.01,{ }^{*} \mathrm{p}<0.05$ 
Table B.3

Regression tables for adjusted maximum likelihood models predicting daily stream export loads for total nitrogen, total phosphorus, and total suspended sediments. Station location is Tualatin River at Dilley (USGS ID 14203500). Explanatory variables are forms of flow and decimal time. Observations are centered to reduce error introduced by multicollinearity.

(for model diagnostics, see Table 3.2)

\begin{tabular}{|c|c|c|c|c|c|c|}
\hline & \multicolumn{2}{|c|}{ Total Nitrogen } & \multicolumn{2}{|c|}{ Total Phosphorus } & \multicolumn{2}{|c|}{ Total Suspended Sediment } \\
\hline $\begin{array}{l}\text { Model } \\
\text { Coefficient }\end{array}$ & Value & Std. Dev. & Value & Std. Dev. & Value & Std. Dev. \\
\hline$a_{0}$ & $5.9542^{* * *}$ & 0.0254 & $3.5009^{* * *}$ & 0.0284 & $9.2037^{* * *}$ & 0.0210 \\
\hline$a_{1}$ & $1.1911^{* * *}$ & 0.0208 & $1.2685^{* * *}$ & 0.0232 & $1.5552^{* * *}$ & 0.0215 \\
\hline$a_{2}$ & $-0.0575^{* * *}$ & 0.0168 & $0.0521^{* *}$ & 0.0188 & $-0.0755^{* * *}$ & 0.0174 \\
\hline$a_{3}$ & $-0.0485^{* *}$ & 0.0186 & 0.0192 & 0.0222 & $-0.0614^{* *}$ & 0.0191 \\
\hline$a_{4}$ & $-0.4905^{* * *}$ & 0.0240 & $-0.2288^{* * *}$ & 0.0260 & $-0.0730^{* *}$ & 0.0251 \\
\hline$a_{5}$ & $-0.0184^{* * *}$ & 0.0018 & $-0.0171^{* * *}$ & 0.0021 & $-0.0107^{* * *}$ & 0.0019 \\
\hline$a_{6}$ & $0.0026^{* * *}$ & 0.0003 & $0.0013^{* * *}$ & 0.0003 & none & \\
\hline
\end{tabular}

Base Model Form

$\ln ($ Load $)=a_{0}+a_{1} \ln Q+a_{2} \ln Q^{2}+a_{3} \sin (2 \pi$ dtime $)+a_{4} \cos (2 \pi$ dtime $)+a_{5}$ dtime $+a_{6}$ dtime ${ }^{2}$

${ }^{* * *} \mathrm{p}<0.001,{ }^{* *} \mathrm{p}<0.01,{ }^{*} \mathrm{p}<0.05$

Table B.4

Regression tables for adjusted maximum likelihood models predicting daily stream export loads for total nitrogen, total phosphorus, and total suspended sediments. Station location is Fanno Creek at Durham (USGS ID 14206950). Explanatory variables are forms of flow and decimal time.

Observations are centered to reduce error introduced by multicollinearity.

(for model diagnostics, see Table 3.2)

\begin{tabular}{lllllll}
\hline & \multicolumn{2}{l}{ Total Nitrogen } & \multicolumn{2}{l}{ Total Phosphorus } & \multicolumn{2}{l}{ Total Suspended Sediment } \\
\hline $\begin{array}{l}\text { Model } \\
\text { Coefficient }\end{array}$ & Value & Std. Dev. & Value & Std. Dev. & Value & Std. Dev. \\
\hline$a_{0}$ & $4.2146^{* * *}$ & 0.0126 & $1.9784^{* * *}$ & 0.0140 & $6.3230^{* * *}$ & 0.0436 \\
$a_{1}$ & $1.1162^{* * *}$ & 0.0087 & $1.1625^{* * *}$ & 0.0084 & $1.7063^{* * *}$ & 0.0260 \\
$a_{2}$ & $-0.0103^{*}$ & 0.0045 & $0.0496^{* * *}$ & 0.0045 & $0.0738^{* * *}$ & 0.0137 \\
$a_{3}$ & 0.0198 & 0.0177 & $-0.3543^{* * *}$ & 0.0169 & $-0.0709^{*}$ & 0.0352 \\
$a_{4}$ & $0.0527^{* * *}$ & 0.0126 & $-0.0776^{* * *}$ & 0.0115 & $0.3364^{* * *}$ & 0.0510 \\
$a_{5}$ & $0.0047^{* *}$ & 0.0015 & $-0.0055^{* * *}$ & 0.0015 & -0.0029 & 0.0045 \\
$a_{6}$ & & $-0.0006^{*}$ & 0.0003 & $-0.0028^{* *}$ & 0.0009 \\
\hline Base Model Form \\
$\ln ($ Load $)=a_{0}+a_{1} \ln Q+a_{2} \ln Q^{2}+a_{3} \sin (2 \pi$ dtime $)+a_{4} \cos (2 \pi d$ dime $)+a_{5}$ dtime $+a_{6}$ dtime \\
${ }^{* * *} \mathrm{p}<0.001,{ }^{* *} \mathrm{p}<0.01,{ }^{*} \mathrm{p}<0.05$ \\
\hline
\end{tabular}


Table B.5

Regression tables for adjusted maximum likelihood models predicting daily stream export loads for total nitrogen, total phosphorus, and total suspended sediments. Station location is the Yamhill DEQ monitoring station. Explanatory variables are forms of flow and decimal time. Observations are centered to reduce error introduced by multicollinearity. (for model diagnostics, see Table 3.2)

\begin{tabular}{|c|c|c|c|c|c|c|}
\hline \multirow{2}{*}{$\begin{array}{l}\text { Model } \\
\text { Coefficient }\end{array}$} & \multicolumn{2}{|c|}{ Total Nitrogen } & \multicolumn{2}{|c|}{ Total Phosphorus } & \multicolumn{2}{|c|}{ Total Suspended Sediment } \\
\hline & Value & Std. Dev. & Value & Std. Dev. & Value & Std. Dev. \\
\hline$a_{0}$ & $6.9476^{* * *}$ & 0.0581 & $4.3074^{* * *}$ & 0.0531 & $9.3096^{* * *}$ & 0.0596 \\
\hline$a_{1}$ & $0.9871^{* * * *}$ & 0.0335 & $1.1192^{* * *}$ & 0.0312 & $1.3990^{* * *}$ & 0.0224 \\
\hline$a_{2}$ & $0.0640^{* * *}$ & 0.0106 & $0.0779^{* * *}$ & 0.0100 & $0.1040^{* * *}$ & 0.0141 \\
\hline$a_{3}$ & -0.0034 & 0.0761 & $-0.2429^{* * *}$ & 0.0426 & & \\
\hline$a_{4}$ & $-0.3601^{* * *}$ & 0.0586 & $-0.1625^{*}$ & 0.0759 & & \\
\hline$a_{5}$ & -0.0045 & 0.0069 & $-0.0134^{* *}$ & 0.0049 & & \\
\hline$a_{6}$ & $0.0052^{*}$ & 0.0021 & $0.0035^{* *}$ & 0.0011 & & \\
\hline \multicolumn{7}{|c|}{$\begin{array}{l}\text { Base Model Form } \\
\ln (\text { Load })=a_{0}+a_{1} \ln Q+a_{2} \ln Q^{2}+a_{3} \sin (2 \pi \text { dtime })+a_{4} \cos (2 \pi d t i m e)+a_{5} \text { dtime }+a_{6} \text { dtime }{ }^{2}\end{array}$} \\
\hline${ }^{* * *} \mathrm{p}<0.001$ & ${ }^{*} \mathrm{p}<0.01$ & 0.05 & & & & \\
\hline
\end{tabular}




\section{Final Calibration Values}

Table B.6

Final calibrated parameter values for InVEST freshwater models in the Tualatin basin. Values in parentheses are parameters for reclassified land cover types. In the water purification model, this is the Wapato Lake region. Some types with small values make up a very small portion of this area, which effectively makes there values insensitive to the final estimate. In the sediment retention model, the reclassification is for the entire Dilley gauge sub-watershed minus the dammed Scoggins Creek watershed.

\begin{tabular}{|c|c|c|c|c|c|c|c|c|c|}
\hline \multirow[b]{2}{*}{$\begin{array}{l}\text { Land Cover } \\
\text { Type }\end{array}$} & \multicolumn{2}{|c|}{ Water Yield } & \multicolumn{4}{|c|}{ Water Purification } & \multicolumn{3}{|c|}{ Sediment Retention } \\
\hline & etk & $\begin{array}{l}\text { Root } \\
\text { Depth }\end{array}$ & TN exp. & $\begin{array}{l}\mathrm{TN} \\
\text { eff. } \\
\text { ret. }\end{array}$ & TP exp. & $\begin{array}{l}\text { TP } \\
\text { eff. } \\
\text { ret. }\end{array}$ & $\begin{array}{l}\mathrm{C} \\
\text { factor }\end{array}$ & $\begin{array}{l}\mathrm{P} \\
\text { factor }\end{array}$ & $\begin{array}{l}\text { eff. } \\
\text { ret. }\end{array}$ \\
\hline Open Water & 1 & 1000 & $\begin{array}{l}850 \\
(2)\end{array}$ & 5 & 165 & 0 & 1 & 1 & 90 \\
\hline $\begin{array}{l}\text { Open } \\
\text { Development }\end{array}$ & 0.9 & 3500 & $\begin{array}{c}17000 \\
(85)\end{array}$ & 5 & $\begin{array}{l}1320 \\
(660)\end{array}$ & 5 & 10 & 350 & 5 \\
\hline $\begin{array}{l}\text { Low } \\
\text { Development }\end{array}$ & 0.9 & 3500 & 32810 & 5 & $\begin{array}{c}2062 \\
(1980)\end{array}$ & 5 & 10 & $\begin{array}{c}120 \\
(100)\end{array}$ & 10 \\
\hline $\begin{array}{l}\text { Medium } \\
\text { Development }\end{array}$ & 0.715 & 2000 & 31620 & 5 & $\begin{array}{c}6600 \\
(6765)\end{array}$ & 5 & 1 & $\begin{array}{c}70 \\
(50)\end{array}$ & 5 \\
\hline $\begin{array}{l}\text { High } \\
\text { Development }\end{array}$ & 0.45 & 300 & 30430 & 5 & $\begin{array}{c}7920 \\
(8250)\end{array}$ & 5 & 1 & 1 & 5 \\
\hline Barren & 0.01 & 10 & 11900 & 2 & 825 & 5 & 250 & 5 & 20 \\
\hline $\begin{array}{l}\text { Deciduous } \\
\text { Forest }\end{array}$ & 0.9 & 6000 & $\begin{array}{c}31110 \\
(37400)\end{array}$ & $\begin{array}{c}30 \\
(20)\end{array}$ & 1485 & $\begin{array}{c}23 \\
(15)\end{array}$ & $\begin{array}{c}1 \\
(3)\end{array}$ & $\begin{array}{c}15 \\
(25)\end{array}$ & $\begin{array}{r}70 \\
(60)\end{array}$ \\
\hline $\begin{array}{l}\text { Evergreen } \\
\text { Forest }\end{array}$ & 0.9 & 6000 & $\begin{array}{c}27625 \\
(27200)\end{array}$ & $\begin{array}{c}25 \\
(12)\end{array}$ & 1485 & $\begin{array}{c}25 \\
(15)\end{array}$ & $\begin{array}{c}1 \\
(3)\end{array}$ & $\begin{array}{c}15 \\
(25)\end{array}$ & $\begin{array}{r}70 \\
(60)\end{array}$ \\
\hline Mixed Forest & 0.9 & 6000 & $\begin{array}{c}29410 \\
(37400)\end{array}$ & $\begin{array}{c}30 \\
(20)\end{array}$ & 1485 & $\begin{array}{c}25 \\
(15)\end{array}$ & $\begin{array}{c}1 \\
(3)\end{array}$ & $\begin{array}{c}15 \\
(25)\end{array}$ & $\begin{array}{r}70 \\
(60)\end{array}$ \\
\hline Shrubland & 0.475 & 2500 & $\begin{array}{c}26010 \\
(27200)\end{array}$ & $\begin{array}{c}15 \\
(12)\end{array}$ & 1980 & 15 & 10 & $\begin{array}{c}15 \\
(25)\end{array}$ & $\begin{array}{r}60 \\
(50)\end{array}$ \\
\hline Grassland & 0.6 & 2500 & $\begin{array}{c}26690 \\
(47600)\end{array}$ & $\begin{array}{c}10 \\
(15)\end{array}$ & 2475 & $\begin{array}{l}12 \\
(8)\end{array}$ & 10 & $\begin{array}{c}15 \\
(25)\end{array}$ & $\begin{array}{r}50 \\
(40)\end{array}$ \\
\hline Pasture/Hay & 0.8 & 1000 & $\begin{array}{c}23800 \\
(170000)\end{array}$ & $\begin{array}{l}10 \\
(5)\end{array}$ & $\begin{array}{c}3135 \\
(3300)\end{array}$ & $\begin{array}{c}8 \\
(8)\end{array}$ & 10 & $\begin{array}{c}20 \\
(31)\end{array}$ & 40 \\
\hline Row Crops & 0.6 & 1500 & $\begin{array}{c}31110 \\
(241400)\end{array}$ & $8(4)$ & $\begin{array}{c}3630 \\
(25905)\end{array}$ & $\begin{array}{c}4 \\
(5)\end{array}$ & $\begin{array}{c}190 \\
(350)\end{array}$ & $\begin{array}{c}30 \\
(50)\end{array}$ & 25 \\
\hline $\begin{array}{l}\text { Woody } \\
\text { Wetlands }\end{array}$ & 1 & 3500 & $\begin{array}{c}3400 \\
(144500)\end{array}$ & $\begin{array}{c}60 \\
(40)\end{array}$ & $\begin{array}{c}2970 \\
(11550)\end{array}$ & $\begin{array}{c}60 \\
(48)\end{array}$ & 10 & 25 & 70 \\
\hline $\begin{array}{l}\text { Emergent } \\
\text { Wetlands }\end{array}$ & 1 & 2500 & $\begin{array}{c}5100 \\
(195500)\end{array}$ & $\begin{array}{c}60 \\
(35)\end{array}$ & $\begin{array}{c}2970 \\
(20625)\end{array}$ & $\begin{array}{c}60 \\
(48)\end{array}$ & 10 & 25 & 70 \\
\hline
\end{tabular}


Table B.7

Final calibrated parameter values for InVEST freshwater models in the Yamhill basin.

\begin{tabular}{|c|c|c|c|c|c|c|c|c|c|}
\hline \multirow[b]{2}{*}{$\begin{array}{l}\text { Land Cover } \\
\text { Type }\end{array}$} & \multicolumn{2}{|c|}{ Water Yield } & \multicolumn{4}{|c|}{ Water Purification } & \multicolumn{3}{|c|}{ Sediment Retention } \\
\hline & etk & $\begin{array}{l}\text { Root } \\
\text { Depth }\end{array}$ & TN exp. & $\begin{array}{l}\text { TN } \\
\text { eff. } \\
\text { ret. }\end{array}$ & TP exp. & $\begin{array}{l}\text { TP } \\
\text { eff. } \\
\text { ret. }\end{array}$ & $\begin{array}{l}\mathrm{C} \\
\text { factor }\end{array}$ & $\begin{array}{l}\mathrm{P} \\
\text { factor }\end{array}$ & $\begin{array}{l}\text { eff. } \\
\text { ret. }\end{array}$ \\
\hline Open Water & 1 & 1000 & 575 & 5 & 140 & 0 & 1 & 1 & 90 \\
\hline $\begin{array}{l}\text { Open } \\
\text { Development }\end{array}$ & 0.9 & 3500 & 11500 & 5 & 1120 & 5 & 10 & 350 & 5 \\
\hline $\begin{array}{l}\text { Low } \\
\text { Development }\end{array}$ & 0.9 & 3500 & 22195 & 5 & 1750 & 5 & 10 & 120 & 10 \\
\hline $\begin{array}{l}\text { Medium } \\
\text { Development }\end{array}$ & 0.715 & 2000 & 21390 & 5 & 5600 & 5 & 1 & 70 & 5 \\
\hline $\begin{array}{l}\text { High } \\
\text { Development }\end{array}$ & 0.45 & 300 & 20858 & 5 & 6720 & 5 & 1 & 1 & 5 \\
\hline Barren & 0.01 & 10 & 8050 & 2 & 700 & 5 & 250 & 5 & 20 \\
\hline $\begin{array}{l}\text { Deciduous } \\
\text { Forest }\end{array}$ & 0.9 & 6000 & 31045 & 30 & 1260 & 23 & 3 & 15 & 70 \\
\hline $\begin{array}{l}\text { Evergreen } \\
\text { Forest }\end{array}$ & 0.9 & 6000 & 18688 & 25 & 1260 & 25 & 3 & 15 & 70 \\
\hline Mixed Forest & 0.9 & 6000 & 19895 & 30 & 1260 & 25 & 3 & 15 & 70 \\
\hline Shrubland & 0.475 & 2500 & 17595 & 15 & 1680 & 15 & 10 & 15 & 60 \\
\hline Grassland & 0.6 & 2500 & 18055 & 10 & 2100 & 12 & 10 & 15 & 50 \\
\hline Pasture/Hay & 0.8 & 1000 & 12880 & 10 & 10640 & 8 & 20 & 62 & 40 \\
\hline Row Crops & 0.6 & 1500 & 168360 & 8 & 12320 & 4 & 330 & 100 & 25 \\
\hline $\begin{array}{l}\text { Woody } \\
\text { Wetlands }\end{array}$ & 1 & 3500 & 2300 & 60 & 2520 & 60 & 10 & 50 & 70 \\
\hline $\begin{array}{l}\text { Emergent } \\
\text { Wetlands }\end{array}$ & 1 & 2500 & 3450 & 60 & 2520 & 60 & 10 & 50 & 70 \\
\hline
\end{tabular}




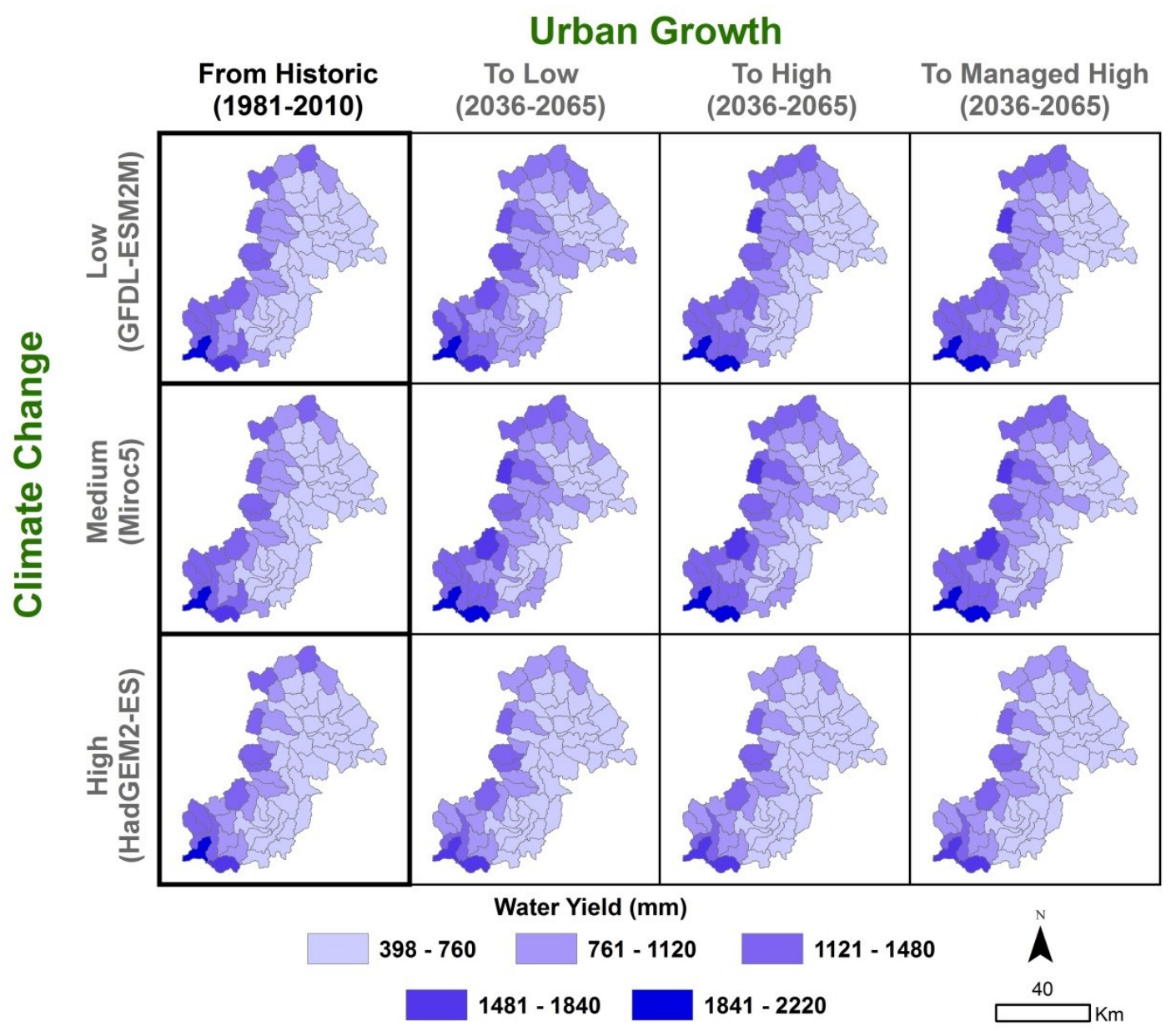

Figure B.4

Matrix of maps depicting scenarios of the InVEST produced estimated amount of water yield (mm per sub-watershed) under climate and land cover change. The left hand column shows historic conditions. Land cover change is represented by either low urbanization, high urbanization, or high urbanization with riparian buffers on the $\mathrm{x}$-axis. Climate change is represented by three climate models representing a spectrum of low to high change with respect to average air temperature on the y-axis. 


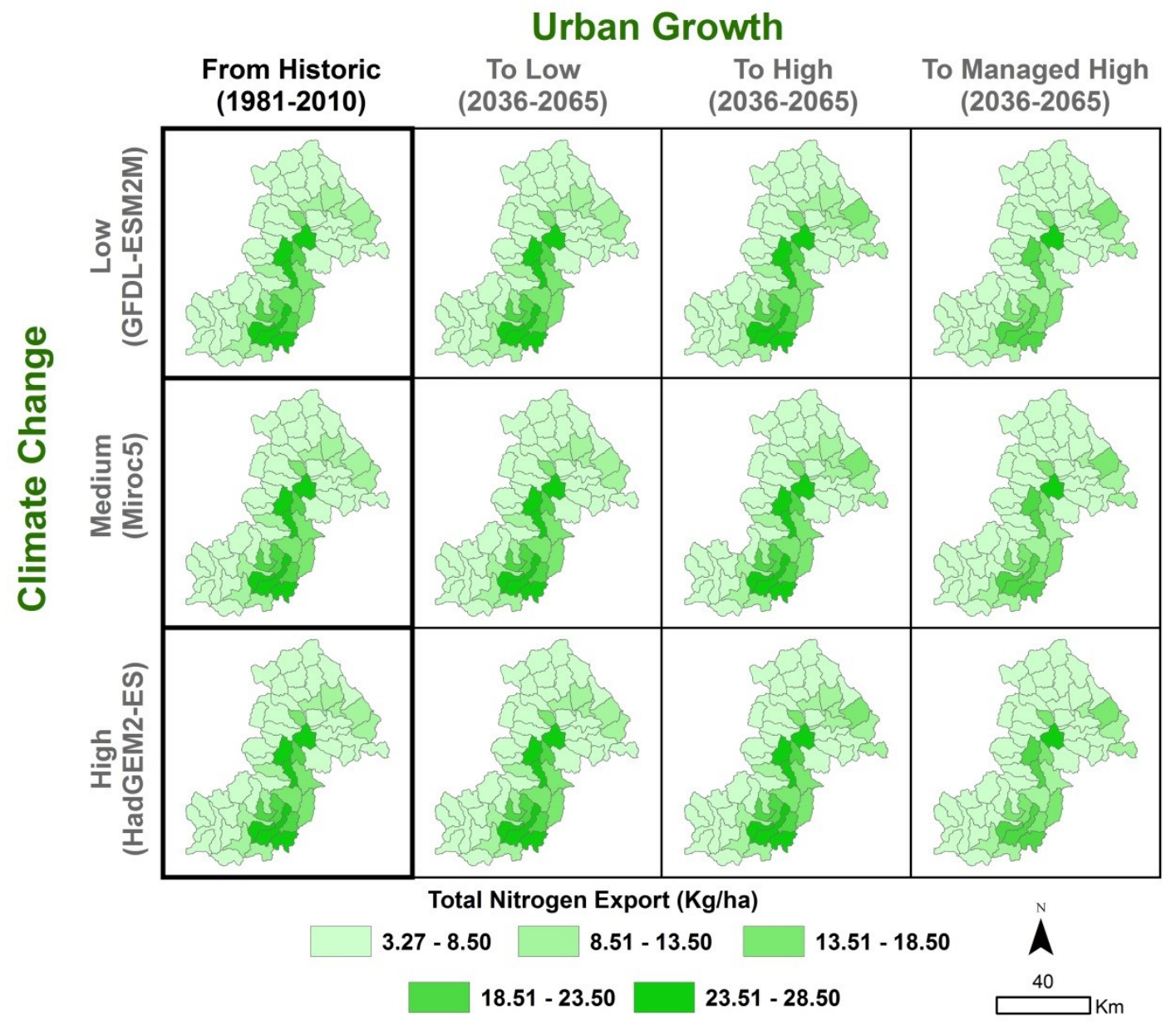

Figure B.5

Matrix depicting scenarios of InVEST produced estimated amount of total nitrogen stream export $(\mathrm{kg} / \mathrm{ha}$ per sub-watershed) under climate and land cover change. Estimates are presented as annual averages for 30 years centered on 2050. The left hand column shows historic conditions or baseline. Land cover change is represented by either low urbanization, high urbanization, or high urbanization with riparian buffers on the $\mathrm{x}$-axis. Climate change is represented by three climate models representing a spectrum of low to high change with respects to air temperature on the y-axis. 


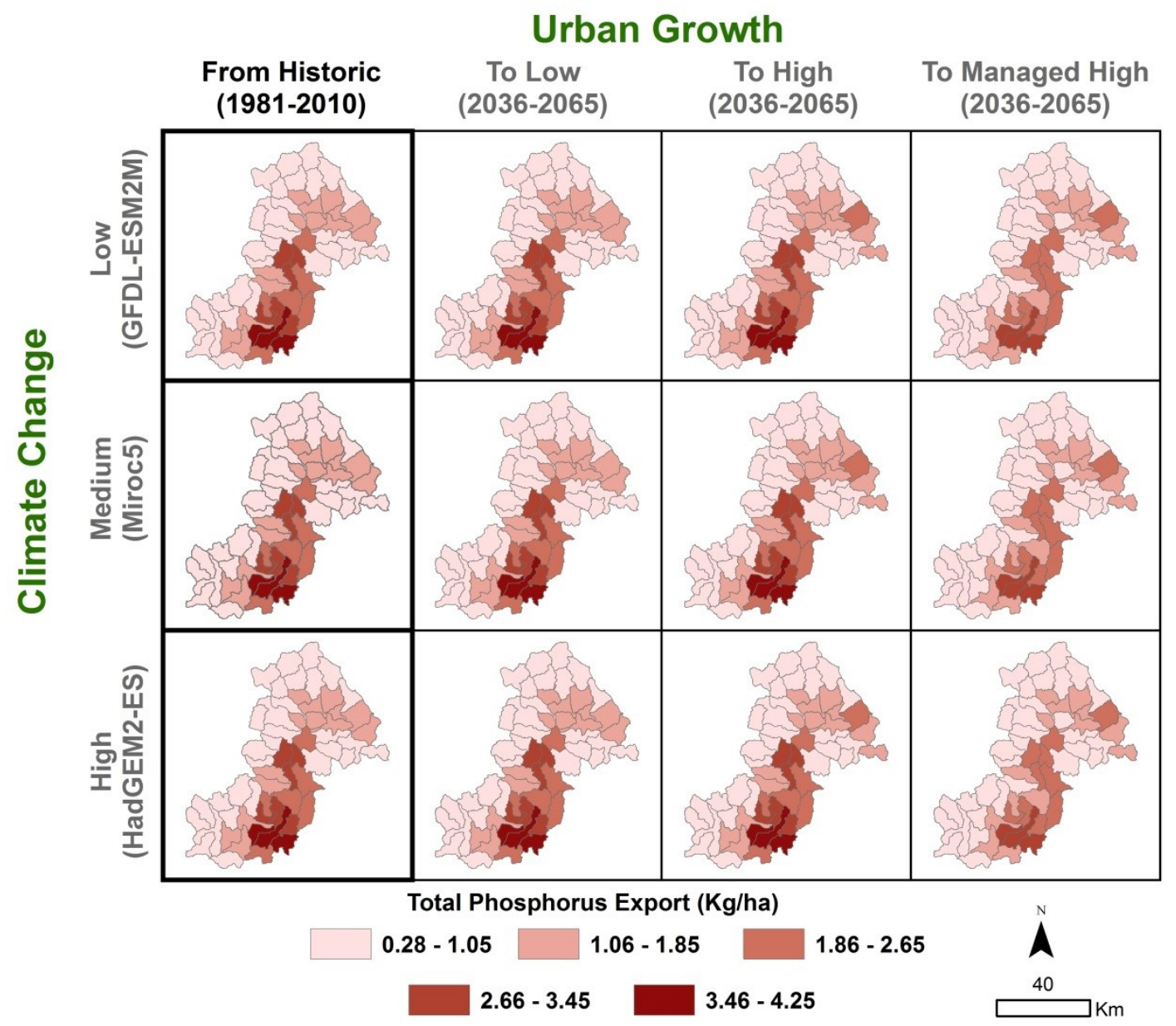

Figure B.6

Matrix depicting scenarios of InVEST produced estimated amount of total phosphorus stream export $(\mathrm{kg} / \mathrm{ha}$ per sub-watershed) under climate and land cover change. Estimates are presented as annual averages for 30 years centered on 2050. The left hand column shows historic conditions or baseline. Land cover change is represented by either low urbanization, high urbanization, or high urbanization with riparian buffers on the $\mathrm{x}$-axis. Climate change is represented by three climate models representing a spectrum of low to high change with respects to air temperature on the y-axis. 


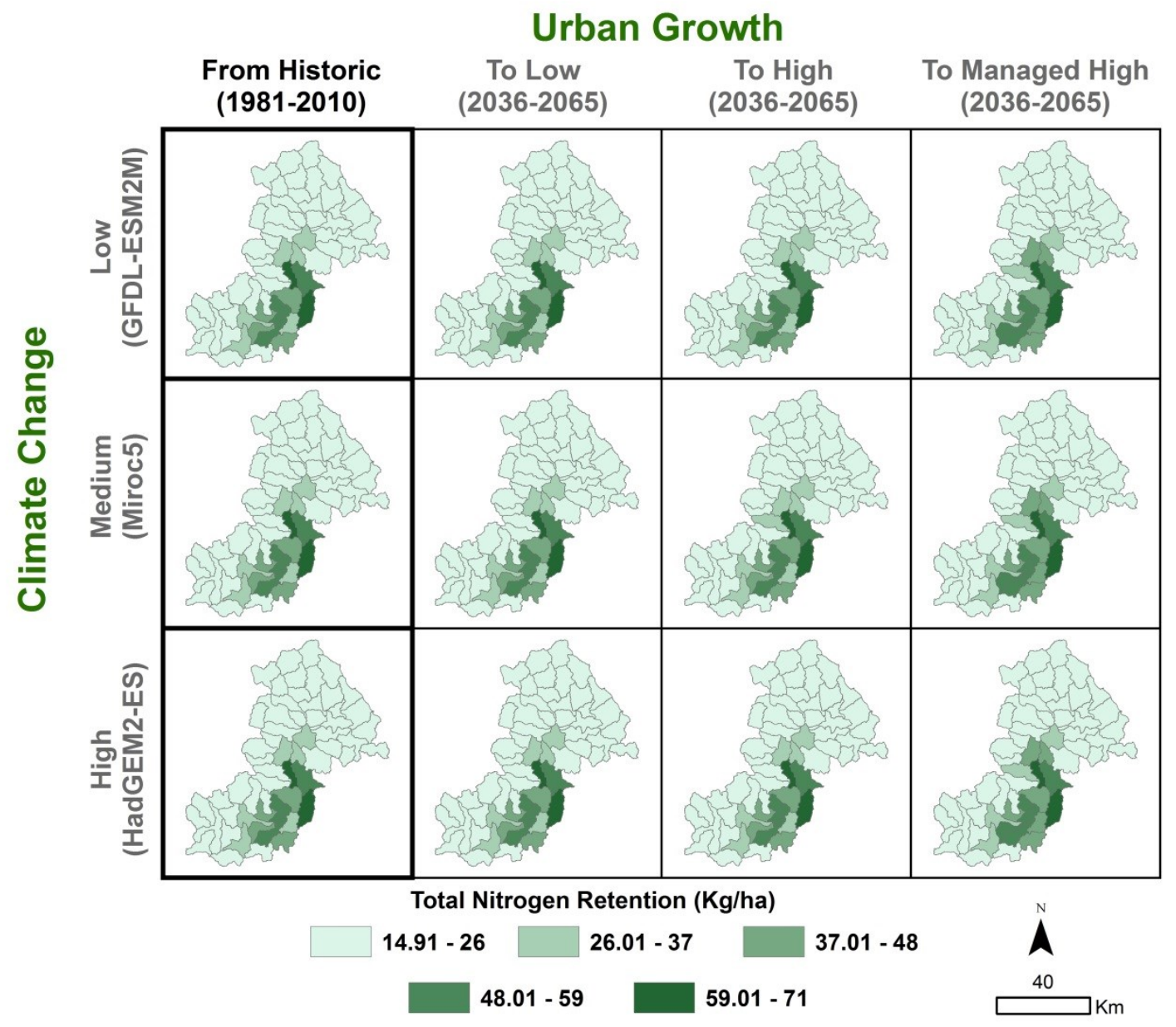

Figure B.7

Matrix depicting scenarios of InVEST produced estimated amount of total nitrogen retention $(\mathrm{kg} / \mathrm{ha}$ per sub-watershed) under climate and land cover change. Estimates are presented as annual averages for 30 years centered on 2050. The left hand column shows historic conditions or baseline. Land cover change is represented by either low urbanization, high urbanization, or high urbanization with riparian buffers on the $\mathrm{x}$-axis. Climate change is represented by three climate models representing a spectrum of low to high change with respects to air temperature on the y-axis. 


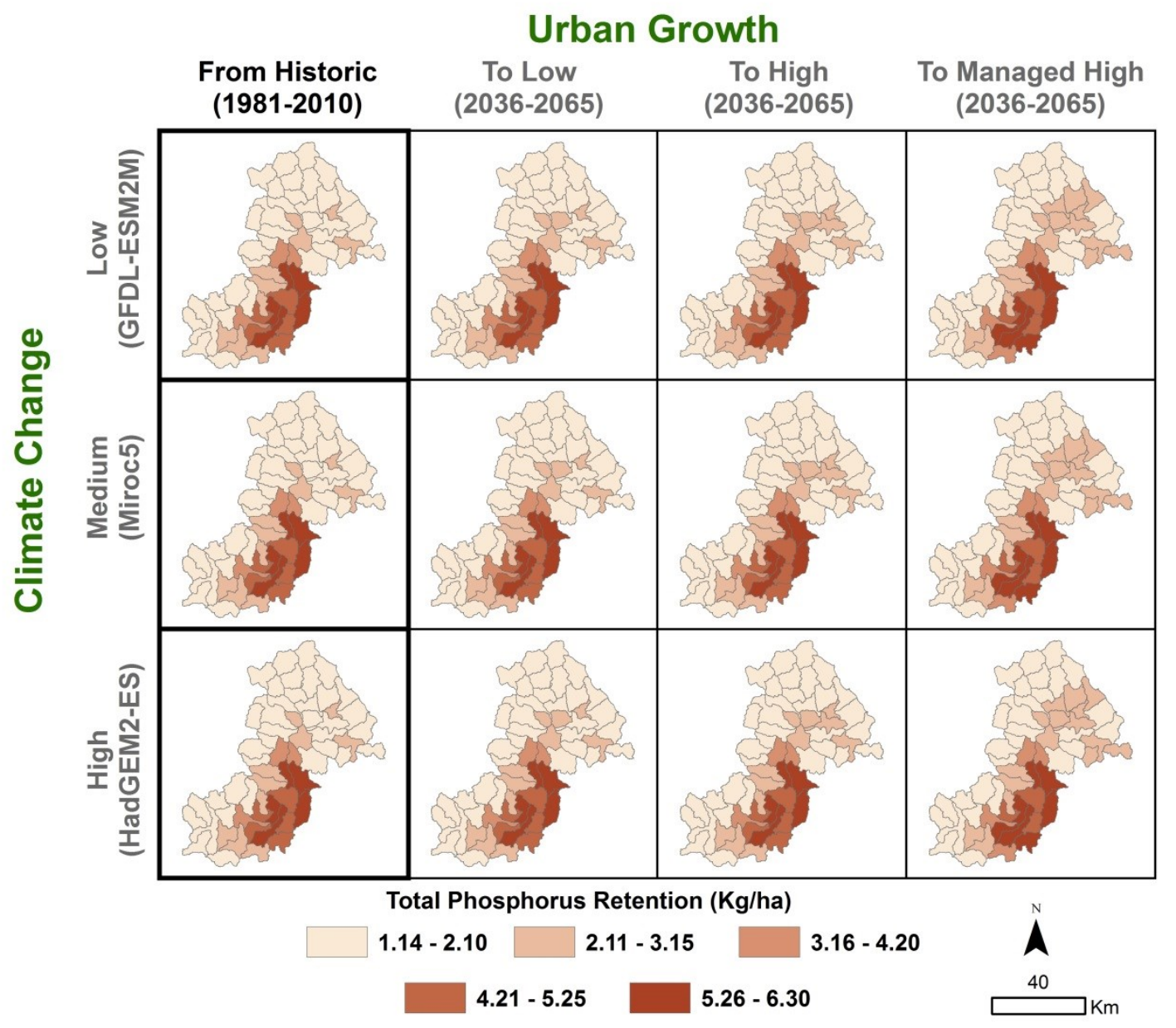

Figure B.8

Matrix depicting scenarios of InVEST produced estimated amount of total phosphorus retention $(\mathrm{kg} / \mathrm{ha}$ per sub-watershed) under climate and land cover change. Estimates are presented as annual averages for 30 years centered on 2050. The left hand column shows historic conditions or baseline. Land cover change is represented by either low urbanization, high urbanization, or high urbanization with riparian buffers on the $\mathrm{x}$-axis. Climate change is represented by three climate models representing a spectrum of low to high change with respects to air temperature on the y-axis. 


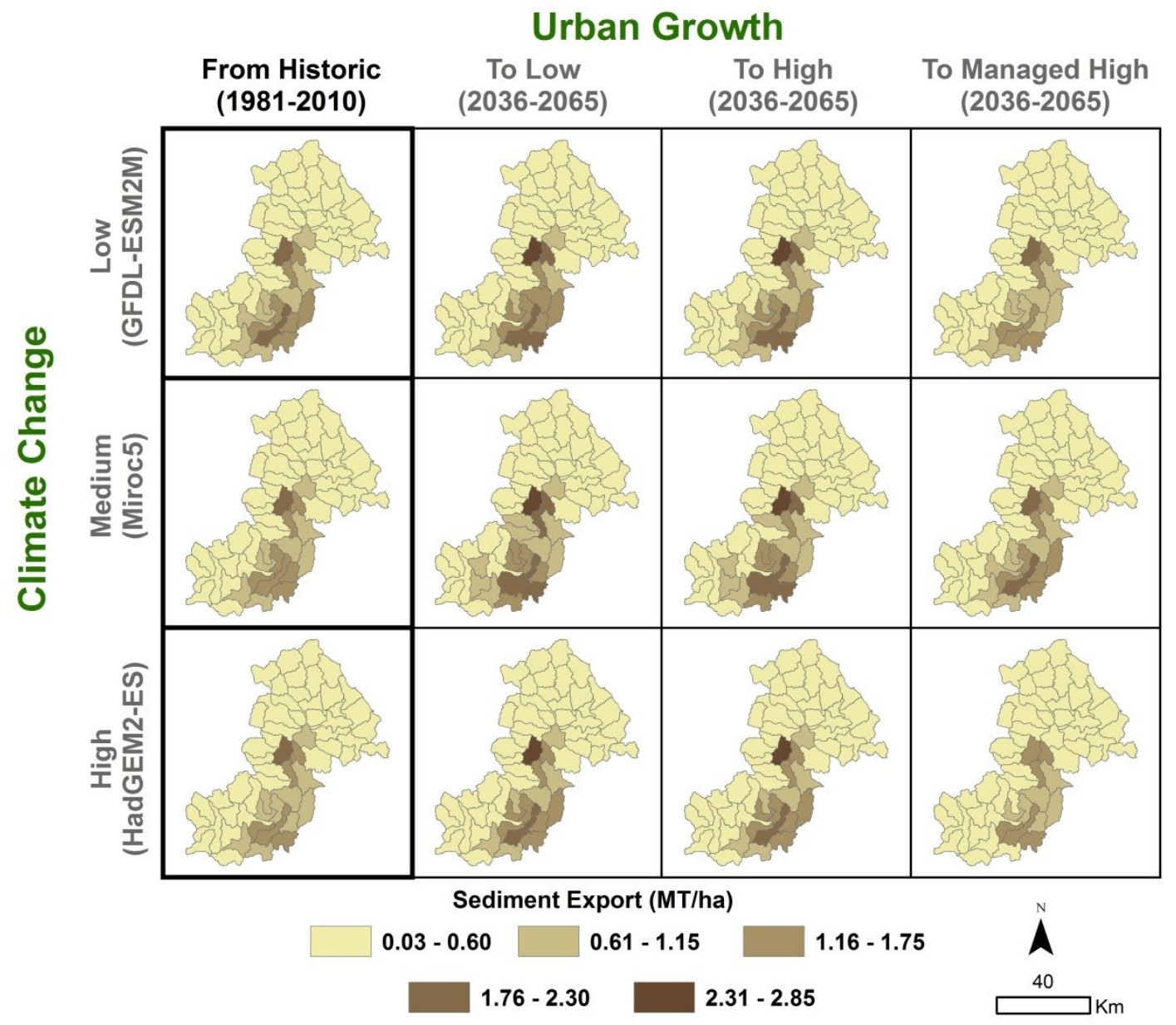

Figure B.9

Matrix depicting scenarios of InVEST produced estimated amount of total suspended sediment stream export ( $\mathrm{kg} / \mathrm{ha}$ per sub-watershed) under climate and land cover change. Estimates are presented as annual averages for 30 years centered on 2050. The left hand column shows historic conditions or baseline. Land cover change is represented by either low urbanization, high urbanization, or high urbanization with riparian buffers on the $\mathrm{x}$-axis. Climate change is represented by three climate models representing a spectrum of low to high change with respects to air temperature on the $y$-axis. 


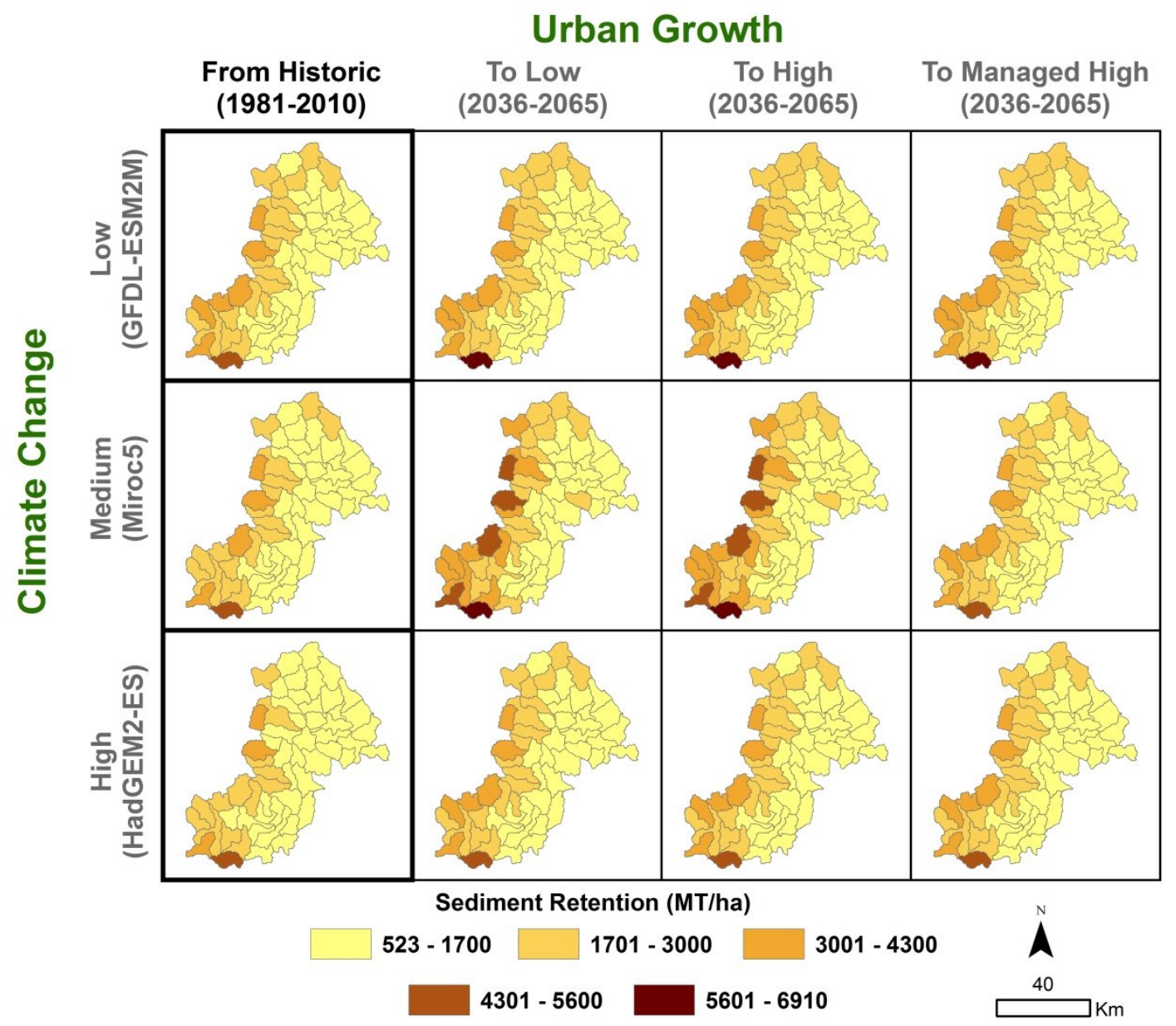

Figure B.10

Matrix depicting scenarios of InVEST produced estimated amount of total sediment retention $(\mathrm{kg} / \mathrm{ha}$ per sub-watershed) under climate and land cover change. Estimates are presented as annual averages for 30 years centered on 2050. The left hand column shows historic conditions or baseline. Land cover change is represented by either low urbanization, high urbanization, or high urbanization with riparian buffers on the $\mathrm{x}$-axis. Climate change is represented by three climate models representing a spectrum of low to high change with respects to air temperature on the y-axis. 


\section{Map Correlation}

Table B. 8

Spearman's rank correlations among InVEST estimates for total nitrogen (TN)/total phosphorus (TP) exports $(\mathrm{Kg} / \mathrm{ha})$ and retention $(\mathrm{Kg} / \mathrm{ha})$ and sediment exports $(\mathrm{MT} / \mathrm{ha})$ and retention $(\mathrm{MT} / \mathrm{ha})$. Estimates are at a sub-watershed scale similar in size to a 12-digit USGS Hydrologic Unit Code (HUC).

\begin{tabular}{llllllll}
\hline $\begin{array}{l}\text { Scenario } \\
\text { LULC/ Climate }\end{array}$ & $\begin{array}{l}\text { TN exp./ } \\
\text { ret. }\end{array}$ & $\begin{array}{l}\text { TP exp./ } \\
\text { ret. }\end{array}$ & $\begin{array}{l}\text { Sed. exp./ } \\
\text { ret. }\end{array}$ & $\begin{array}{l}\text { TN exp./ } \\
\text { TP exp. }\end{array}$ & $\begin{array}{l}\text { TN ret./ } \\
\text { TP ret. }\end{array}$ & $\begin{array}{l}\text { TP exp./ } \\
\text { Sed. exp. }\end{array}$ & $\begin{array}{l}\text { TP ret./ } \\
\text { Sed. ret. }\end{array}$ \\
\hline $\begin{array}{l}\text { Current/ } \\
\text { Low Historic }\end{array}$ & $0.704^{* * *}$ & $0.924^{* * *}$ & $-0.422^{* * *}$ & $0.940^{* * *}$ & $0.700^{* * *}$ & $0.940^{* * *}$ & $0.700^{* * *}$ \\
$\begin{array}{l}\text { Current/ } \\
\text { Med. Historic }\end{array}$ & $0.705^{* * *}$ & $0.923^{* * *}$ & $-0.447^{* * *}$ & $0.942^{* * *}$ & $0.699^{* * *}$ & $0.942^{* * *}$ & $0.699^{* * *}$ \\
$\begin{array}{l}\text { Current/ } \\
\text { High Historic }\end{array}$ & $0.703^{* * *}$ & $0.923^{* * *}$ & $-0.445^{* * *}$ & $0.940^{* * *}$ & $0.698^{* * *}$ & $0.940^{* * *}$ & $0.698^{* * *}$ \\
$\begin{array}{l}\text { Low/ } \\
\text { Low Future }\end{array}$ & $0.683^{* * *}$ & $0.928^{* * *}$ & $-0.422^{* * *}$ & $0.944^{* * *}$ & $0.686^{* * *}$ & $0.944^{* * *}$ & $0.686^{* * *}$ \\
$\begin{array}{l}\text { Low/ } \\
\text { Med. Future }\end{array}$ & $0.686^{* * *}$ & $0.928^{* * *}$ & $-0.328^{*}$ & $0.945^{* * *}$ & $0.689^{* * *}$ & $0.945^{* * *}$ & $0.686^{* * *}$ \\
$\begin{array}{l}\text { Low/ } \\
\text { High Future }\end{array}$ & $0.681^{* * *}$ & $0.930^{* * *}$ & $-0.473^{* * *}$ & $0.942^{* * *}$ & $0.679^{* * *}$ & $0.942^{* * *}$ & $0.679^{* * *}$ \\
$\begin{array}{l}\text { High/ } \\
\text { Low Future }\end{array}$ & $0.649^{* * *}$ & $0.929^{* * *}$ & $-0.443^{* * *}$ & $0.949^{* * *}$ & $0.666^{* * *}$ & $0.949^{* * *}$ & $0.666^{* * *}$ \\
$\begin{array}{l}\text { High/ } \\
\text { Med. Future }\end{array}$ & $0.658^{* * *}$ & $0.930^{* * *}$ & $-0.359^{* *}$ & $0.950^{* * *}$ & $0.669^{* * *}$ & $0.950^{* * *}$ & $0.669^{* * *}$ \\
$\begin{array}{l}\text { High/ } \\
\text { High Future }\end{array}$ & $0.649^{* * *}$ & $0.930^{* * *}$ & $-0.483^{* * *}$ & $0.948^{* * *}$ & $0.658^{* * *}$ & $0.948^{* * *}$ & $0.658^{* * *}$ \\
$\begin{array}{l}\text { Managed High/ } \\
\text { Low Future }\end{array}$ & $0.651^{* * *}$ & $0.927^{* * *}$ & $-0.452^{* * *}$ & $0.935^{* * *}$ & $0.671^{* * *}$ & $0.935^{* * *}$ & $0.671^{* * *}$ \\
$\begin{array}{l}\text { Managed High/ } \\
\text { Med. Future }\end{array}$ & $0.656^{* * *}$ & $0.927^{* * *}$ & $-0.494^{* * *}$ & $0.935^{* * *}$ & $0.673^{* * *}$ & $0.935^{* * *}$ & $0.673^{* * *}$ \\
$\begin{array}{l}\text { High Fut High / } \\
\text { Migh Futre }\end{array}$ & $0.649^{* * *}$ & $0.927^{* * *}$ & $-0.498^{* * *}$ & $0.931^{* * *}$ & $0.661^{* * *}$ & $0.931^{* * *}$ & $0.661^{* * *}$ \\
\hline
\end{tabular}

${ }^{* * *} \mathrm{p}<0.001,{ }^{* *} \mathrm{p}<0.01,{ }^{*} \mathrm{p}<0.05$, two-tailed 


\section{B.3 Additional Informaation}

\section{InVEST Model Structure Summary}

Table B.9

Integrated Valuation of Environmental Services and Tradeoffs (InVEST) water yield model structure. Equation taken from Tallis et al. (2013), which provides detailed explanations of the models. Kareiva et al. (2011) provide additional explanation of the theoretical underpinning of the model.

Water Yield

(per pixel estimate of annual water yield)

Evapotranspiration Partition

(per pixel estimate of the fraction of the water lost to evapotranspiration to from total precipitation)

Dimensionless ratio of plant available water capacity of soil to annual average precipitation $\left(\omega_{x}\right)$

Budyko Dryness Index $\left(R_{x j}\right)$

(describes the relative aridity of a pixel based climate and

$$
\begin{aligned}
& Y_{x j}=\left(1-\frac{A E T_{x j}}{P_{x}}\right) \\
& \frac{A E T_{x j}}{P_{x}}=\frac{1+\omega_{x} R_{x j}}{1+\omega_{x} R_{x j}+\frac{1}{R_{x j}}} \\
& \omega_{x}=Z \frac{A W C_{x}}{P_{x}} \\
& R_{x j}=\frac{k_{x j} \cdot E T o_{x}}{P_{x}}
\end{aligned}
$$
tation)

$Y_{x j}$ : Water Yield at pixel $x$ of land use/land cover (LULC) category $j$

$A E T_{x j}$ : Actual Evapotranspiration at pixel $x$ of LULC category $j$

$P_{x}$ : Precipitation at pixel $x$

$Z$ : Zhang coefficient, an integer form 1 to 10,1 describes humid areas with even rain event distribution or summer rains, 10 describes areas of predominant winter rains

$A W C_{x}$ : Plant available water capacity, amount of water that held in soil, and then released for plant use at pixel $\mathrm{x}$

$k_{x j}$ : evapotranspiration coefficient at pixel $x$ of LULC (vegetation) $j$

$E T o_{x}$ : Reference evapotranspiration (also known as potential evapotranspiration - PET) at pixel $j$ 
Table B. 10

Integrated Valuation of Environmental Services and Tradeoffs (InVEST) water purification model structure. Equation taken from Tallis et al. (2013), which provides detailed explanations of the models. Kareiva et al. (2011) provide additional explanation of the theoretical underpinning of the model.

Adjusted Loading Value (a pixel's contributing nutrient load adjusted by the hydrologic sensitivity score)

Hydrologic Sensitivity Score (a pixel's relative wetness or dryness compared to the mean for the whole watershed)

Runoff Index

(describes a pixel's wetness or dryness based on it and all upstream pixels' runoff)

$$
\begin{gathered}
A L V_{x}=H S S_{x} \cdot p o l_{x} \\
H S S_{x}=\frac{\lambda_{x}}{\overline{\lambda_{W}}} \\
\lambda_{x}=\log \left(\sum_{U} Y_{U}\right)
\end{gathered}
$$

pol $_{x}$ : export coefficient at pixel $x$

$\overline{\lambda_{W}}$ : mean runoff index in watershed of interest $\sum_{U} Y_{U}$

\begin{tabular}{|c|c|c|c|c|}
\hline Cell & $\begin{array}{l}\text { Vegetation (Land } \\
\text { Cover) Retention (\%) } \\
\text { Efficiency }\end{array}$ & ALV & Retention by Cell & $\begin{array}{l}\text { Outflow Quantity From Cell } \\
\left(G_{i}=1-E_{i}\right)\end{array}$ \\
\hline 1 & $\mathrm{E}_{1}$ & $\mathrm{ALV}_{1}$ & 0 & $\mathrm{ALV}_{1}$ \\
\hline 2 & $\mathrm{E}_{2}$ & $\mathrm{ALV}_{2}$ & $\mathrm{ALV}_{1} \times \mathrm{E}_{1}$ & $\mathrm{ALV}_{1} \times \mathrm{G}_{2}+\mathrm{ALV}_{2}$ \\
\hline 3 & $\mathrm{E}_{3}$ & $\mathrm{ALV}_{3}$ & $\begin{array}{l}\left(\mathrm{ALV}_{1} \times \mathrm{G}_{2}+\right. \\
\left.\mathrm{ALV}_{2}\right) \times \mathrm{E}_{3}\end{array}$ & $\left(A L V_{1} \times G_{2}+A L V_{2}\right) \times G_{3}+A L V_{3}$ \\
\hline 4 & $\mathrm{E}_{4}$ & $\mathrm{ALV}_{4}$ & $\begin{array}{l}\mathrm{ALV}_{1} \times \mathrm{G}_{2} \times \mathrm{G}_{3} \times \\
\mathrm{E}_{4}+ \\
\mathrm{ALV}_{2} \times \mathrm{G}_{3} \times \mathrm{E}_{4}+ \\
\mathrm{ALV}_{3} \times \mathrm{E}_{4}\end{array}$ & $\begin{array}{l}\mathrm{ALV} \\
\mathrm{ALV}_{2} \times \mathrm{G}_{2} \times \mathrm{G}_{3} \times \mathrm{G}_{4}+ \\
\mathrm{ALV}_{3} \times \mathrm{G}_{4}+ \\
\mathrm{ALV}_{4}\end{array}$ \\
\hline
\end{tabular}
: sum of the water yield of the pixels above pixel $x$

Effective Retention Routine

(illustration of algorithm used to determine the amount of a nutrient retained or exported by a pixel) 
Table B.11

Integrated Valuation of Environmental Services and Tradeoffs (InVEST) sediment retention model structure. Equation taken from Tallis et al. (2013), which provides detailed explanations of the models. Kareiva et al. (2011) provide additional explanation of the theoretical underpinning of the model.

\begin{tabular}{|c|c|}
\hline $\begin{array}{l}\text { Length Slope Factor for low slopes (used below } \\
\text { the LS threshold, determines LS factor of the } \\
\text { Universal Soil Loss Equation) }\end{array}$ & $\begin{aligned} L S & =\left(\frac{\text { flowacc } \text { cellsize }}{22.13}\right)^{n n}\left(\left(\frac{\sin (\text { slope } \cdot 0.01745)}{0.09}\right)^{1.4}\right) * 1.6 \\
n n & =\left\{\begin{array}{l}0.5, \text { slope } \geq 5 \% \\
0.4,3.5<\text { slope }<5 \% \\
0.3,1<\text { slope } \leq 3.5 \% \\
0.2, \text { slope } \leq 1 \%\end{array}\right.\end{aligned}$ \\
\hline $\begin{array}{l}\text { Length Slope Factor for high slopes (used } \\
\text { above the LS threshold, determines LS factor of } \\
\text { the Universal Soil Loss Equation) }\end{array}$ & $\begin{array}{l}L S=0.08 \lambda^{0.35} \text { prct_slope } e^{0.6} \\
\lambda=\left\{\begin{array}{c}\text { cellsize }, \text { flowdir }=1,4,16, \text { or } 64 \\
1.4 \cdot \text { cellsize }, \text { other flowdir }\end{array}\right.\end{array}$ \\
\hline $\begin{array}{l}\text { Potential Soil Loss (only factors of USLE that } \\
\text { determine mobilization of soil) }\end{array}$ & $R K L S=R \times K \times L S$ \\
\hline Universal Soil Loss Equation (USLE) & $U S L E=R \times K \times L S \times C \times P$ \\
\hline
\end{tabular}

flowacc: the accumulated to flow to each cell

cellsize: pixel size or grid/ raster resolution

slope: percent slope of a pixel

cellsize: pixel size or grid/raster resolution

flowdir: direction of flow out of a pixel

$R$ : Rainfall Erosivity Factor

$K$ : Soil Erodibility Factor

$C$ : Crop Factor

$P$ : Management Factor

Effective Retention Routine

(illustration of algorithm used to determine the amount of a sediment retained or exported by a pixel)

\begin{tabular}{|c|c|c|c|c|}
\hline Cell & $\begin{array}{l}\text { Vegetation } \\
\text { (Land Cover) } \\
\text { Retention (\%) } \\
\text { Efficiency }\end{array}$ & USLE & Retention by Cell & $\begin{array}{l}\text { Outflow Quantity From Cell } \\
\left(\mathrm{G}_{\mathrm{i}}=1-\mathrm{E}_{\mathrm{i}}\right)\end{array}$ \\
\hline 1 & $\mathrm{E}_{1}$ & $\mathrm{USLE}_{1}$ & 0 & USLE $_{1}$ \\
\hline 2 & $\mathrm{E}_{2}$ & USLE $_{2}$ & $\mathrm{USLE}_{1} \times \mathrm{E}_{1}$ & $\mathrm{USLE}_{1} \times \mathrm{G}_{2}+\mathrm{USLE}_{2}$ \\
\hline 3 & $\mathrm{E}_{3}$ & $\mathrm{USLE}_{3}$ & $\begin{array}{l}\left(\mathrm{USLE}_{1} \times \mathrm{G}_{2}+\right. \\
\left.\mathrm{USLE}_{2}\right) \times \mathrm{E}_{3}\end{array}$ & $\begin{array}{l}\left(\mathrm{USLE}_{1} \times \mathrm{G}_{2}+\mathrm{USLE}_{2}\right) \times \mathrm{G}_{3}+ \\
\mathrm{USLE}_{3}\end{array}$ \\
\hline 4 & $\mathrm{E}_{4}$ & USLE $_{4}$ & $\begin{array}{l}\mathrm{USLE}_{1} \times \mathrm{G}_{2} \times \mathrm{G}_{3} \times \\
\mathrm{E}_{4}+ \\
\mathrm{USLE}_{2} \times \mathrm{G}_{3} \times \mathrm{E}_{4}+ \\
\mathrm{USLE}_{3} \times \mathrm{E}_{4}\end{array}$ & $\begin{array}{l}\mathrm{USLE}_{1} \times \mathrm{G}_{2} \times \mathrm{G}_{3} \times \mathrm{G}_{4}+ \\
\mathrm{USLE}_{2} \times \mathrm{G}_{3} \times \mathrm{G}_{4}+ \\
\mathrm{USLE}_{3} \times \mathrm{G}_{4}+ \\
\mathrm{USLE}_{4}\end{array}$ \\
\hline
\end{tabular}


Appendix B References

Arnold, J. G., Moriasi, D. N., Gassman, P. W., Abbaspour, K. C., White, M. J., Srinivasan, R., Santhi, C., Harmel, R. D., van Griensven, A., Van Liew, M. W., Kannan, N., \& Jha, M. K. (2012). SWAT: Model Use, Calibration, and Validation. Transaction of the American Society of Agricultural and Biological Engineers, 55(4), 1491-1508.

Beguería, S., \& Vicente-Serrano, S. M. (2013). SPEI: Calculation of the Standardized Precipitation-Evapotranspiration Index: R package (Version 1.3) [Software]. Available from http://CRAN.R-project.org/package=SPEI

NWIS (National Water Information System). (2013).USGS Surface-water daily data for the nation [Data file]. Retrieved from http://waterdata.usgs.gov/nwis/dv/?referred_module=sw

R Core Team. (2013). R: A language and environment for statistical computing. R Foundation for Statistical Computing [Computer Software]. Vienna: Austria.Avaialble from http://www.R-project.org/

Runkel, R. L., Crawford, C. G., \& Cohn, T. A. (2004). Load Estimator (LOADEST): A Fortran program for estimating constituent loads in streams and rivers (US Geological Survey Techniques and Methods: 4-A). http://pubs.usgs.gov/tm/2005/tm4A5/

Wapato Improvement District. (2009). Wapato Lake Water Quality Management Plan for Wapato Improvement District. Retrieved from http://tualatinriverkeepers.org/files4download/Wapato\%20mp\%20jul\%2009.pdf 